\author{
UNIVERSIDADE DE SÃO PAULO (USP) \\ FACULDADE DE FILOSOFIA, LETRAS E CIÊNCIAS HUMANAS \\ DEPARTAMENTO DE GEOGRAFIA \\ PROGRAMA DE PÓS-GRADUAÇÃO EM GEOGRAFIA FÍSICA
}

JÉSSICAVIEIRA DE FARIA

Paisagens de Torre de Pedra (SP): avaliação do potencial geoecológico das paisagens e subsídios ao planejamento territorial (Versão corrigida)

Dissertação de Mestrado 


\author{
UNIVERSIDADE DE SÃO PAULO (USP) \\ FACULDADE DE FILOSOFIA, LETRAS E CIÊNCIAS HUMANAS \\ DEPARTAMENTO DE GEOGRAFIA \\ PROGRAMA DE PÓS-GRADUAÇÃO EM GEOGRAFIA FÍSICA
}

JÉSSICA VIEIRA DE FARIA

\title{
Paisagens de Torre de Pedra (SP): avaliação do potencial geoecológico das paisagens e subsídios ao planejamento territorial
}

(Versão corrigida)

Dissertação de Mestrado apresentada ao Programa de Pós-Graduação em Geografia Física do Departamento de Geografia da Faculdade de Filosofia, Letras e Ciências Humanas da Universidade de São Paulo como requisito para obtenção do título de Mestre em Ciências.

Linha de pesquisa: Paisagem e planejamento ambiental

Orientador: Prof. Dr. Yuri Tavares Rocha 
Autorizo a reprodução e divulgação total ou parcial deste trabalho, por qualquer meio convencional ou eletrônico, para fins de estudo e pesquisa, desde que citada a fonte.

Catalogação na Publicação Serviço de Biblioteca e Documentação

Faculdade de Filosofia, Letras e Ciências Humanas da Universidade de São Paulo

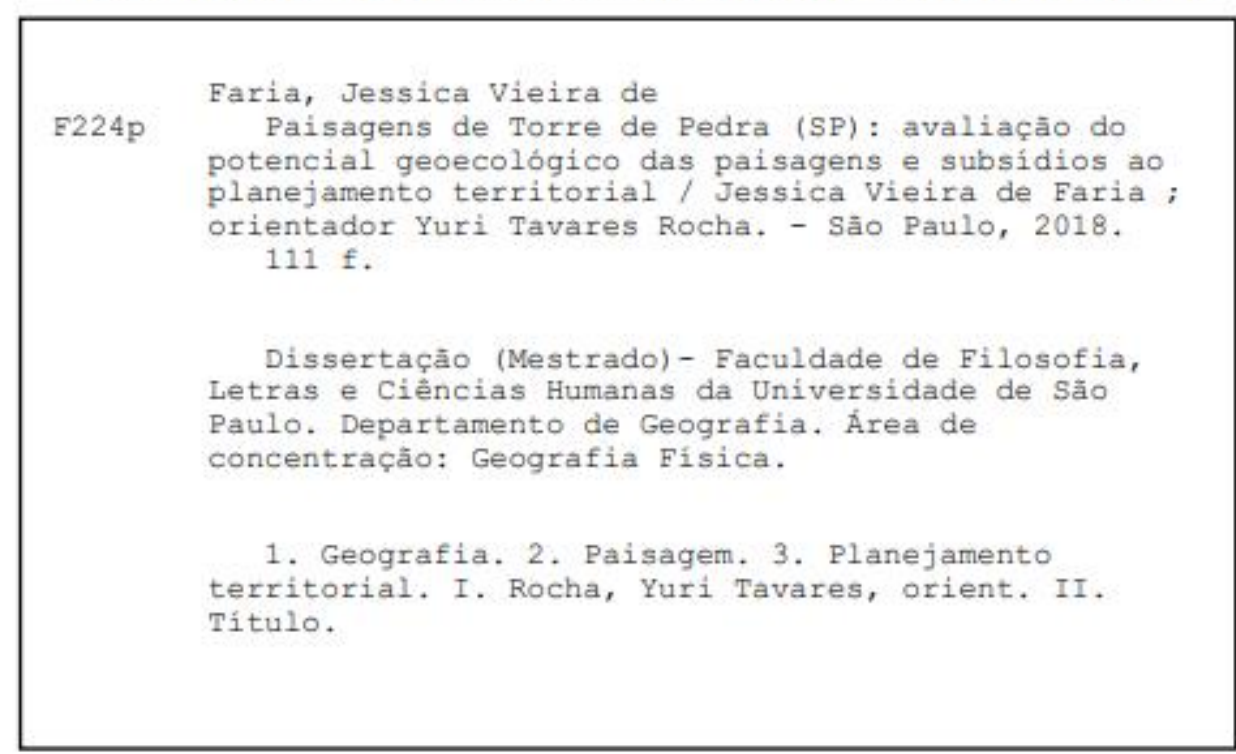




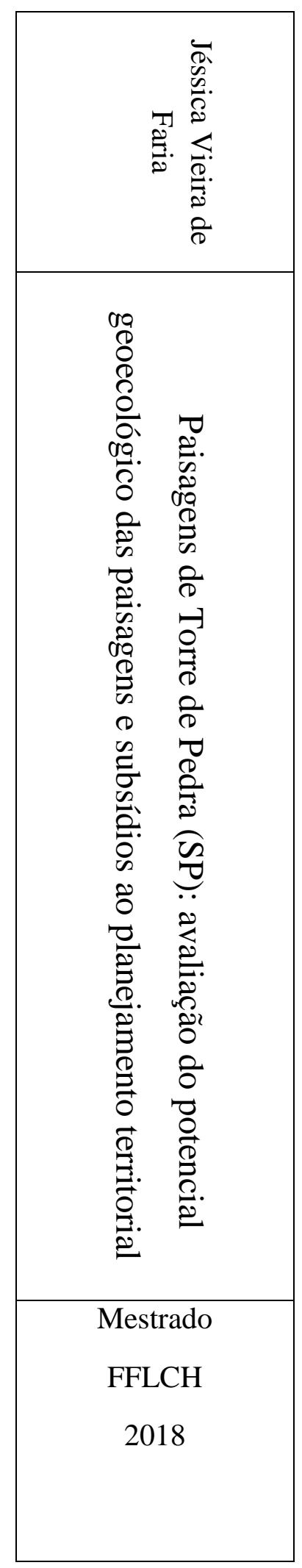




\title{
Paisagens de Torre de Pedra (SP): avaliação do potencial geoecológico das paisagens e subsídios ao planejamento territorial
}

\begin{abstract}
Dissertação de Mestrado apresentada ao Programa de Pós-Graduação em Geografia Física do Departamento de Geografia da Faculdade de Filosofia, Letras e Ciências Humanas da Universidade de São Paulo como requisito para obtenção do título de Mestre em Ciências.
\end{abstract}

\section{BANCA EXAMINADORA}

Prof. Dr. Yuri Tavares Rocha (Orientador) Departamento de Geografia - Universidade de São Paulo

Profa. Dra. Ana Maria Marques Camargo Marangoni - Departamento de Geografia Universidade de São Paulo

Prof. Dr. Adenilson Francisco Bezerra - Instituto Federal de São Paulo

Prof. Dr. José Eduardo dos Santos - Universidade Federal de São Carlos 
Para Jacira, Luiz Carlos, Firmino, Jaira, Vicentina e Acácio. 


\section{AGRADECIMENTOS}

Agradeço ao Prof. Yuri, pela ajuda, orientação e compreensão ao longo desses anos.

Aos professores Jurandyr Ross e Ana Marangoni, pelas observações feitas durante a banca de qualificação e que contribuíram muito para o aprofundamento da pesquisa.

Ao IGC, especificamente Thiago, que me auxiliou com as bases cartográficas da pesquisa.

Ao Arquivo Público do Estado de São Paulo, pelo fornecimento de fotografias aéreas históricas da área de estudo.

Às chefias profissionais que tive e amigos editoriais que fiz, que incentivaram o desenvolvimento dessa pesquisa mesmo com a jornada integral de trabalho.

Aos meus pais, pelo apoio e amor a mim dedicados desde sempre.

Ao Gledson, pelo amor, apoio e paciência durante tantos anos.

Aos meus familiares, que me apoiaram de longe e de perto (Sônia e Everton, especialmente, que me auxiliaram durante os trabalhos de campo).

À Vivian e Thais, que me acompanham desde o início da minha jornada geográfica.

Aos moradores de Torre de Pedra (SP), muito solícitos e interessados no mote dessa pesquisa sempre.

Aos colegas do programa de pós-graduação e a tantos outros amigos que me acompanharam pelas rampas do prédio da Geografia/História. 
I am no longer accepting the things I cannot change.

I am changing the things I cannot accept.

Angela Davis 


\section{RESUMO}

O relevo paulista apresenta algumas peculiaridades no tocante a formas geomorfológicas excepcionais. Um exemplo é o morro residual conhecido como Torre de Pedra, no interior do estado. Este morro residual, cuja localização é próxima ao relevo de cuestas, foi influenciado pelo processo de circundenudação nas bordas da Depressão Periférica Paulista, Bacia do Paraná. Dado a presença destes morros testemunhos no relevo paulista e a preocupação de algumas instâncias de órgãos públicos em preservar os monumentos geológicos do estado, a pesquisa analisou possibilidades de uso do solo na região e verificou a possibilidade de promover o turismo na área, sob a perspectiva dos estudos do planejamento da paisagem. Dessa forma, o objetivo geral da pesquisa foi avaliar o potencial geoecológico das unidades de paisagens do município de Torre de Pedra (SP), principalmente do morro testemunho e seu entorno. Para isso, houve uma avaliação do estado ambiental prévio da área de estudo. Em seguida, houve a delimitação das unidades de paisagem, que abrangeu os seguintes critérios: unidades geomorfológicas, formas de relevo e padrão de uso e cobertura do solo. Simultaneamente, foi realizado levantamento bibliográfico sobre modos de turismo em que a geodiversidade é destacada. Como resultado, delimitou-se quatro principais unidades de paisagem na área de estudo e verificou-se que há diversas potencialidades nas unidades de paisagens, inclusive potencial turístico. Essa pesquisa contribuiu para levantar indicações de uso e cobertura do solo que podem dar subsídios para o planejamento territorial da área de estudo.

Palavras-chave: turismo, geoturismo, unidades de paisagem, benefícios ecossistêmicos, morro-testemunho, Torre de Pedra. 


\begin{abstract}
São Paulo estate relief presents some peculiarities regarding exceptional geomorphological forms. An example is the residual hill known as Torre de Pedra, inside the state. This residual hill, whose location is close to slope relief, was influenced by the process of circumundation on the edges of the Depressão Periférica, Paraná Basin. Due to the presence of these testimonial hills in the state of São Paulo and the concern of some instances of public organizations in preserving the state's geological monuments, the research analyzed possibilities of land use in the region and verified the possibility of promoting tourism in the area, from the perspective of landscape planning studies. Thus, the general objective of the research is to evaluate the geoecological potential of the landscapes of the city of Torre de Pedra (SP), mainly of the residual hill and its surroundings. For this, there was an evaluation of the previous environmental state of the study area. The delimitation of the landscape units covered the following criteria: geomorphological units, relief forms and pattern of use and soil cover. Simultaneously, there will be a bibliographical survey on modes of tourism in which geodiversity is highlighted. As results, four landscape units were delimited and several potentialities of the landscapes of the study area were verified during the research, including tourist potential. This research contributed to raise indications of land use and land cover that support the territorial planning of the study area.
\end{abstract}

Key words: tourism, geotourism, landscape units, ecosystem services, residual relief, Torre de Pedra. 
Figura 1: Imagem de localização do polígono representando a área de estudo. Município

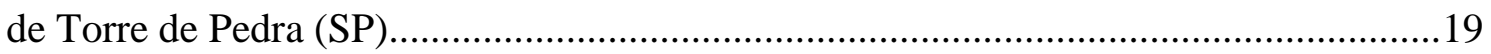

Figura 2: Fotografia da vila de Torre de Pedra em 1942 ............................................20

Figura 3: Fotografia da vila de Torre de Pedra em 1972 ...............................................20

Figura 4: Fotografia da Torre de Pedra, no município de Torre de Pedra (SP)..............22

Figura 5: Esquema sobre a formação das cuestas. .........................................................23

Figura 6: Morro agudo, outra forma do tipo morro-testemunho distante cerca de três quilômetros da Torre de Pedra. .................................................................................. 24

Figura 7: Perfil de elevação do Morro agudo e Torre de Pedra .....................................24

Figura 8: Litoestatigrafia da Bacia do Paraná..............................................................25

Figura 9: Polígono representativo da APA Corumbataí, Botucatu, Tejupá, Perímetro

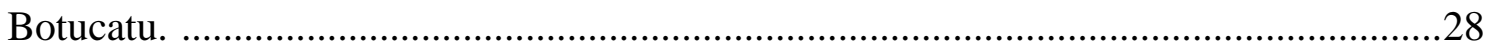

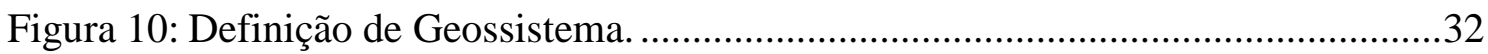

Figura 11: Algoritmo para a elaboração de contribuições ecológicas para a paisagem. 38 Figura 12: Fotografia de vegetação com características de Mata Atlântica no município

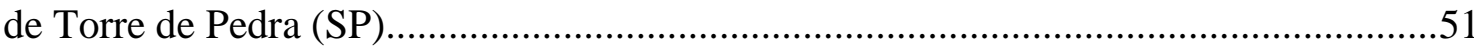

Figura 13: Fotografia de vegetação com características de Cerrado no sopé do morrotestemunho Torre de Pedra, no município de Torre de Pedra (SP) . ...............................51

Figura 14: Fotografia de córrego próximo ao morro-testemunho Torre de Pedra, no município de Torre de Pedra (SP).

Figura 15: Delimitação das cuestas e morro-testemunhos na APA Corumbataí, Botucatu

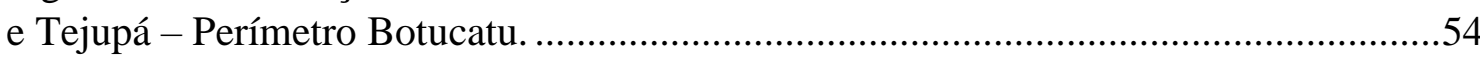

Figura 16: Figuras com a composição do zoneamento de parte do município de Torre de Pedra de acordo com o plano de manejo da APA Corumbataí, Botucatu e Tejupá -

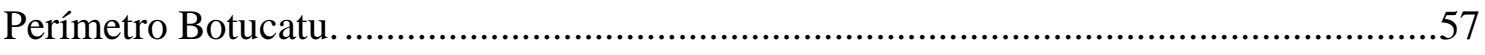

Figura 17: Silvicultura nas proximidades do morro-testemunho Torre de Pedra.

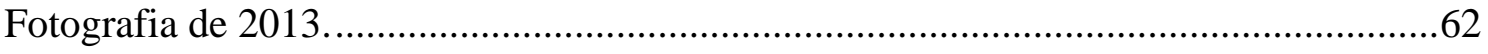

Figura 18: Degradação no sopé do morro-testemunho Torre de Pedra. ..........................63

Figura 19: Pisoteio em área de pastagem em terreno íngreme no espigão da Areia Branca, entre os municípios de Torre de Pedra e Guareí.

Figura 20: Pontos de coletas de dados do primeiro trabalho de campo no município de Torre de Pedra (SP), sem escala.

Figuras 21 e 22: À esquerda, ponte na entrada da cidade sobre córrego afluente do Rio Feio. À direita, córrego afluente do Rio Feio com má conservação das matas ciliares. 67 Figura 23: Afluente do rio Feio recebendo despejo direto de esgoto, no município de Torre de Pedra (SP).

Figura 24: Morros na direção da cuesta vistos a partir do sopé do morro-testemunho Torre de Pedra. 
Figura 25: Feições erosivas em terreno íngreme no espigão da Areia Branca, entre os municípios de Torre de Pedra e Guareí (SP)

Figura 26: Erosão do solo ao longo da cerca que delimita o terreno onde fica o Morro Agudo, em Torre de Pedra (SP)

Figura 27: Centro urbano de Torre de Pedra (SP).

Figura 28: Vista da cuesta a partir do espigão da Areia Branca, divisa entre os municípios de Torre de Pedra e Guareí. ...........................................................................70

Figura 29: Morro-testemunho Torre de Pedra ............................................................ 70

Figura 30: Detalhe do morro-testemunho Torre de Pedra. .............................................. 71

Figura 31: Foto aérea do monumento Torre de Pedra de 1940 ........................................72

Figura 32: Foto do monumento Torre de Pedra de 2018 ............................................72

Figura 33: Pontos de coletas de dados do segundo trabalho de campo...........................73

Figura 34: Colinas de topos convexos na zona nordeste do município de Torre de Pedra.

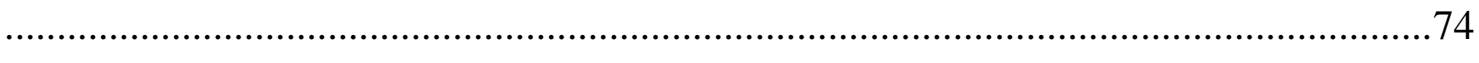

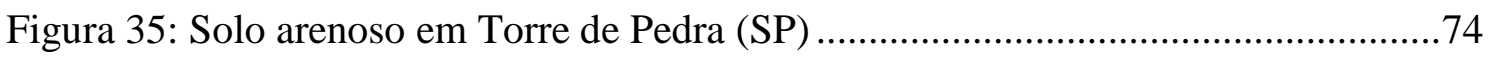

Figura 36: Entrada de granja filiada a empresa JBS em Torre de Pedra (SP) .................75

Figura 37: Feições erosivas relacionadas ao pisoteio do gado em Torre de Pedra (SP).

Figura 38: Feições erosivas relacionadas ao pisoteio do gado em Torre de Pedra (SP).

Figura 39: Sede da Associação de Produtores Rurais de leite de Torre de Pedra. ..........77

Figura 40: Silvicultura em Torre de Pedra (SP), fora da abrangência da APA. .............77

Figura 41: Entrada da Fazenda São Jorge, no quilômetro 172 da Rodovia Castelo

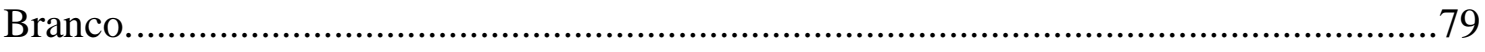

Figura 42: Acesso a mineração de areia na Fazenda São Jorge ...................................79

Figura 43: Morros convexos do Espigão da Areia Branca. .............................................83

Figura 44: Perfil de elevação da divisa entre Torre de Pedra e Guareí (SP) ....................83

Figura 45: Diferentes tipos de solo observados durante os trabalhos de campo ..............86

Figura 46: Diferentes tipos de solo observados durante os trabalhos de campo .............86

Figura 47: Imagem de satélite Google Earth/CPRM utilizada para o mapeamento de uso do solo. .88

Lista de quadros

Quadro 1: Definições de paisagem sob abordagem sistêmica.......................................29

Quadro 2: Quadro comparativo de classificação de unidades de paisagem ......................34

Quadro 3: Bases cartográficas utilizadas na pesquisa ..................................................48

Quadro 4: Descrição das zonas e recomendações da APA ..........................................57

Quadro 5: Quadro de diretrizes para atividades de pesquisa na APA Corumbataí, Botucatu e Tejupá - Perímetro Botucatu.........................................................................59

Quadro 6: Quadro com as características das UPs delimitadas .....................................93 
Quadro 7: Levantamento preliminar de impactos ambientais .98

Quadro 8: Benefícios ecossistêmicos das unidades de paisagem de Torre de Pedra (SP)

\section{Lista de fluxogramas}

Fluxograma 1: Desmembramento dos municípios que deram origem ao município de Torre de Pedra.

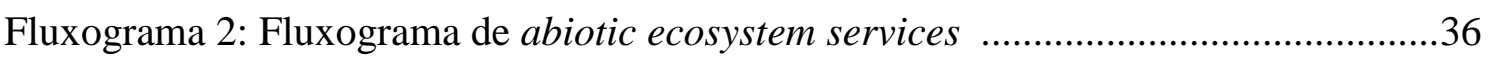

Fluxograma 3: Etapas metodológicas. .............................................................................44

Fluxograma 4: Critérios de delimitação das unidades de paisagem ...............................46

Fluxograma 5: Rede urbana dos municípios da APA Corumbataí, Botucatu e Tejupá -

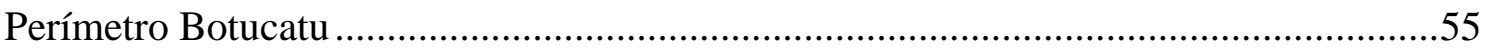

\section{Lista de mapas}

Mapa 1: Mapa da APA Corumbataí, Botucatu e Tejupá - Perímetro Botucatu .50

Mapa 2: Mapa da exploração do Aquífero Guarani na APA Corumbataí, Botucatu e Tejupá - Perímetro Botucatu

Mapa 3: Tipologia dos municípios da APA Corumbataí, Botucatu e Tejupá - Perímetro

Botucatu, baseadas no PIB municipal (2007).

Mapa 4: Mapa de atividades de mineração na APA Corumbataí, Botucatu e Tejupá -

Perímetro Botucatu.

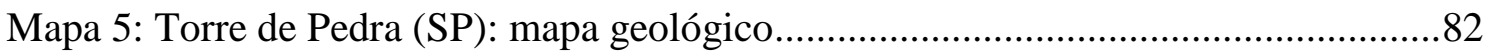

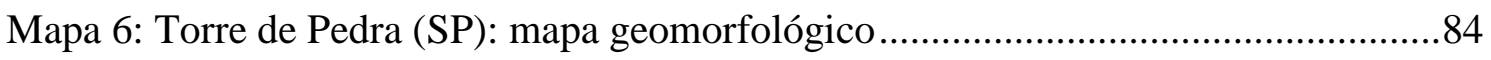

Mapa 7: Torre de Pedra (SP): dissecação do relevo .......................................................85

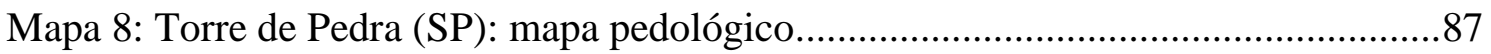

Mapa 9: Torre de Pedra (SP): uso do solo e cobertura vegetal .....................................89

Mapa 10: Torre de Pedra (SP): área do município inserida na APA...............................90

Mapa 11: Torre de Pedra (SP): unidades de paisagem................................................92

Mapa 12: APA Corumbataí, Botucatu, Tejupá - Perímetro Botucatu ...........................97 
Lista de abreviações

APA - Área de Proteção Ambiental

COMGEO - Conselho Estadual de Monumentos Geológicos do Estado de São Paulo IG - Instituto Geológico

IBGE - Instituto Brasileiro de Geografia e Estatística

SMA - Secretaria do Meio Ambiente de São Paulo

SNUC - Sistema Nacional de Unidades de Conservação

MTur - Ministério do Turismo

UC - Unidades de Conservação

UP - Unidade de paisagem 
1. Introdução

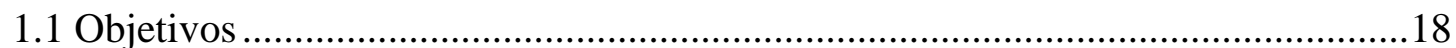

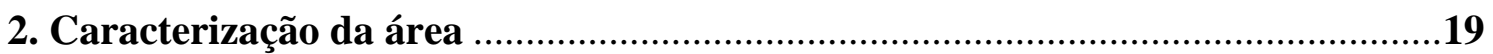

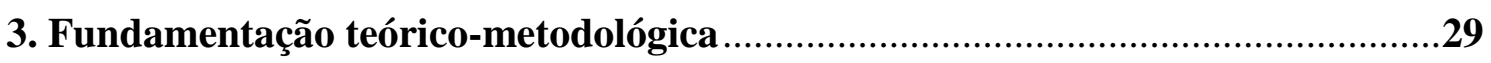

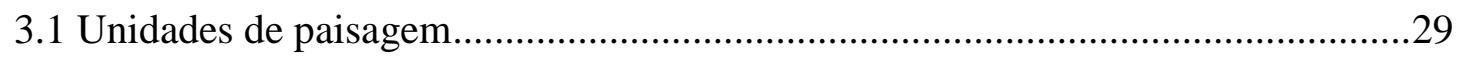

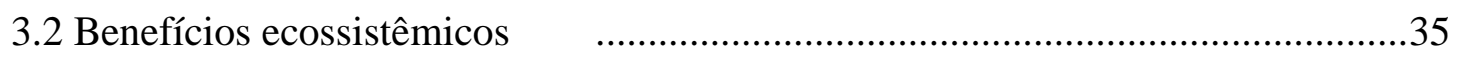

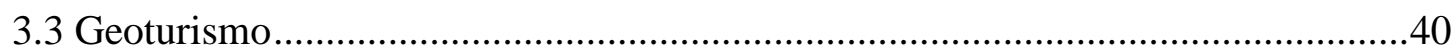

4. Procedimentos metodológicos e operacionais .......................................................44

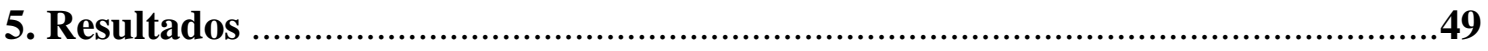

5.1 Avaliação da situação atual da área de estudo …………………………………....49

5.2 Trabalhos de campo ..................................................................................6

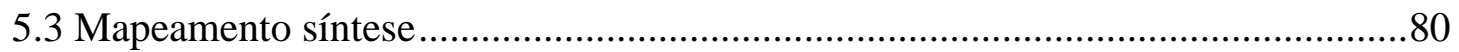

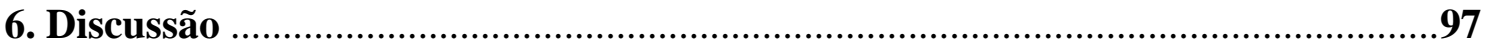

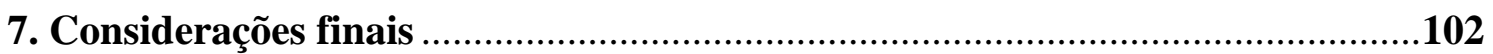

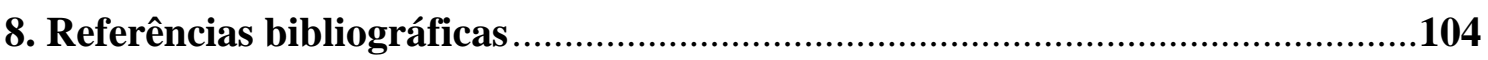

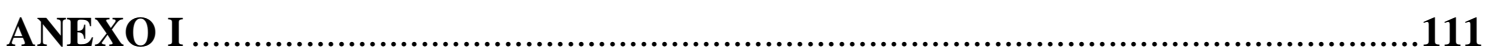




\section{INTRODUÇÃO}

O relevo, enquanto registro na superfície terrestre de eventos passados, apresenta formações específicas que podem contribuir para a compreensão dos processos geomorfológicos. Há também formações excepcionais, tais como os morro-testemunhos de eras geológicas passadas, além de afloramentos de camadas antigas expostas pela erosão e outros exemplos que contribuem para essa compreensão dos processos geomorfológicos (AB’SABER, 1949).

No caso do relevo paulista, há algumas peculiaridades no tocante a formas geomorfológicas excepcionais. Um exemplo é o morro-testemunho conhecido como Torre de Pedra, no interior do estado. Este morro-testemunho, cuja localização é próxima ao relevo do cuestas $^{1}$ no município homônimo de Torre de Pedra, foi influenciado pela ação de erosão nas bordas da bacia da Depressão Periférica, Bacia do Paraná (AB`SABER, 1949). Esta erosão semi-circular, denominada por Ab’Saber de circundenudação, deu origem ao relevo de cuestas, geradas nos movimentos cenozóicos (ALMEIDA, 1949). Porém, não há estudos suficientes sobre possíveis usos para ela, a fim de preservá-la, mas também mantê-la economicamente ativa. Em visitas a campo realizadas para reconhecimento prévio da área de estudo, foram encontrados lixo, pichações e outras marcas de degradação ambiental na área.

O Conselho Estadual de Monumentos Geológicos do Estado de São Paulo (CoMGeo), subordinado à Secretaria do Estado do Meio Ambiente, visa a divulgação dos Monumentos Geológicos do estado de São Paulo, além de medidas de preservação e pesquisas relacionadas a essas áreas. Atualmente, o órgão considera sete monumentos geológicos no estado: Varvito de Itu, no município de Itu/SP; Rocha Moutonnée, em Salto/SP; Cavernas e Carste do Parque Estadual Turístico do Alto Ribeira (PETAR); Cratera de Colônia, em São Paulo/SP; Pedra do Baú, em São Bento do Sapucaí/SP; Morro do Diabo, em Teodoro Sampaio/SP e Geiseritos, em Anhembi/SP. O morro-testemunho Torre de Pedra não está incluso no inventário do ComGeo.

Dada a presença destes morro-testemunhos e a preocupação de órgãos públicos em preservar os monumentos geológicos do estado de São Paulo, pesquisas relacionadas

\footnotetext{
${ }^{1}$ Cuestas são formas de relevo assimétricas inclinadas em bacias sedimentares, cujos mergulhos da inclinação vão em direção ao centro dessas bacias (CASSETI, 2005).
} 
a essas estruturas excepcionais do relevo são necessárias para ampliar o conhecimento e as pesquisas sobre essas regiões e subsidiar possíveis decisões de políticas públicas.

No Brasil, mais especificamente a partir da década de 1990, procura-se associar o turismo a práticas sustentáveis de preservação ambiental. Existem diversas modalidades de turismo que podem ocorrer em área rural (caso do município de Torre de Pedra): agroturismo, turismo em espaço rural, ecoturismo (NOVAES, 2006). No caso da área de estudo, uma nova abordagem turística pode ser analisada: o Geoturismo, que parte do pressuposto de que a atividade turística deve ser associada a programas de conservação do ponto turístico visitado e de conscientização dos fenômenos geológicos e geográficos associados à região (NEWSOME E DOWLING, 2010).

Todos os fatores citados acima, a preocupação com o desenvolvimento de formas alternativas de turismo, com a fragilidade dos diferentes ecossistemas e a preservação ambiental de estruturas geomorfológicas excepcionais mostram a importância do tema e a relevância dos estudos que visam entender a dinâmica da paisagem nessas áreas.

Os procedimentos metodológicos da pesquisa se pautaram na análise integrada de paisagens. Propõe-se o mapeamento das unidades de paisagem com base em critérios prédeterminados, avaliando as potencialidades e restrições naturais de cada unidade identificada. Para isso, foram realizados levantamentos bibliográficos, mapeamentos síntese das unidades de paisagem, trabalhos de campo para coleta de dados primários e tratamento de dados após campo.

As seguintes questões e suposições são norteadoras da pesquisa:

a) Há diferentes potencialidades identificadas nas paisagens do município de Torre de Pedra? Dentre essas potencialidades, há potencial turístico associado ao morrotestemunho lá existente?

b) Quais são os usos de solo favoráveis à preservação ambiental das paisagens do município de Torre de Pedra?

As variáveis do trabalho estão relacionadas aos critérios selecionados para a delimitação das unidades de paisagem:

- Variável teórica: unidades de paisagem definida por sua função e dinâmica

- Variáveis operacionais: uso e ocupação do solo, forma de relevo, pedologia, litologia.

Após essa análise, foi realizada pesquisa bibliográfica sobre formas de turismo associadas a áreas de geodiversidade destacada, áreas de turismo associado a formações 
geomorfológicas excepcionais, geoparques e turismo em áreas de Área de Proteção Ambiental (APA).

Verificou-se que a área de estudo apresenta recomendações diversas e heterogêneas de uso - além da possibilidade de se desenvolver atividades econômicas dento da área de APA. A pesquisa apresenta argumentos técnicos e geográficos que sugerem diferentes tipos de uso do solo como meio de preservação dos morrotestemunhos do município de Torre de Pedra.

\section{$\underline{1.1 \text { Objetivos }}$}

O objetivo geral da pesquisa é avaliar o potencial geoecológico das unidades de paisagens do município de Torre de Pedra, focando no potencial turístico dessas paisagens, além de verificar a existência de planos de manejo da APA que está na área de estudo e outras propostas municipais. Assim, a pesquisa também visou fornecer subsídios para o planejamento territorial e exploração da beleza cênica do morro-testemunho. 


\section{CARACTERIZAÇÃO DA ÁREA}

A área de estudo abrange o município de Torre de Pedra, região centro-oeste do estado de São Paulo, na altura do quilômetro 167 da Rodovia Castelo Branco (Figura 1). Encontra-se na região administrativa de Sorocaba, São Paulo, mesorregião de Itapetininga e à microrregião de Tatuí (IBGE, 2018).

A população total do município foi estimada em 2.395 habitantes pelo IBGE, em 2017. Antigo distrito da cidade de Porangaba, Torre de Pedra foi emancipada em 1991 (IBGE, 2018). O município possui uma área de $71,3 \mathrm{~km}^{2}$, fazendo limite municipal com Bofete, Porangaba e Guareí. Assim, a densidade demográfica do município é 31,59 hab./km². Em relação aos indicadores socioeconômicos, o Índice de Desenvolvimento Humano Municipal (IDHM) de 2010 era 0,714 e o PIB per capita era R\$ 9.382,85 (2015).

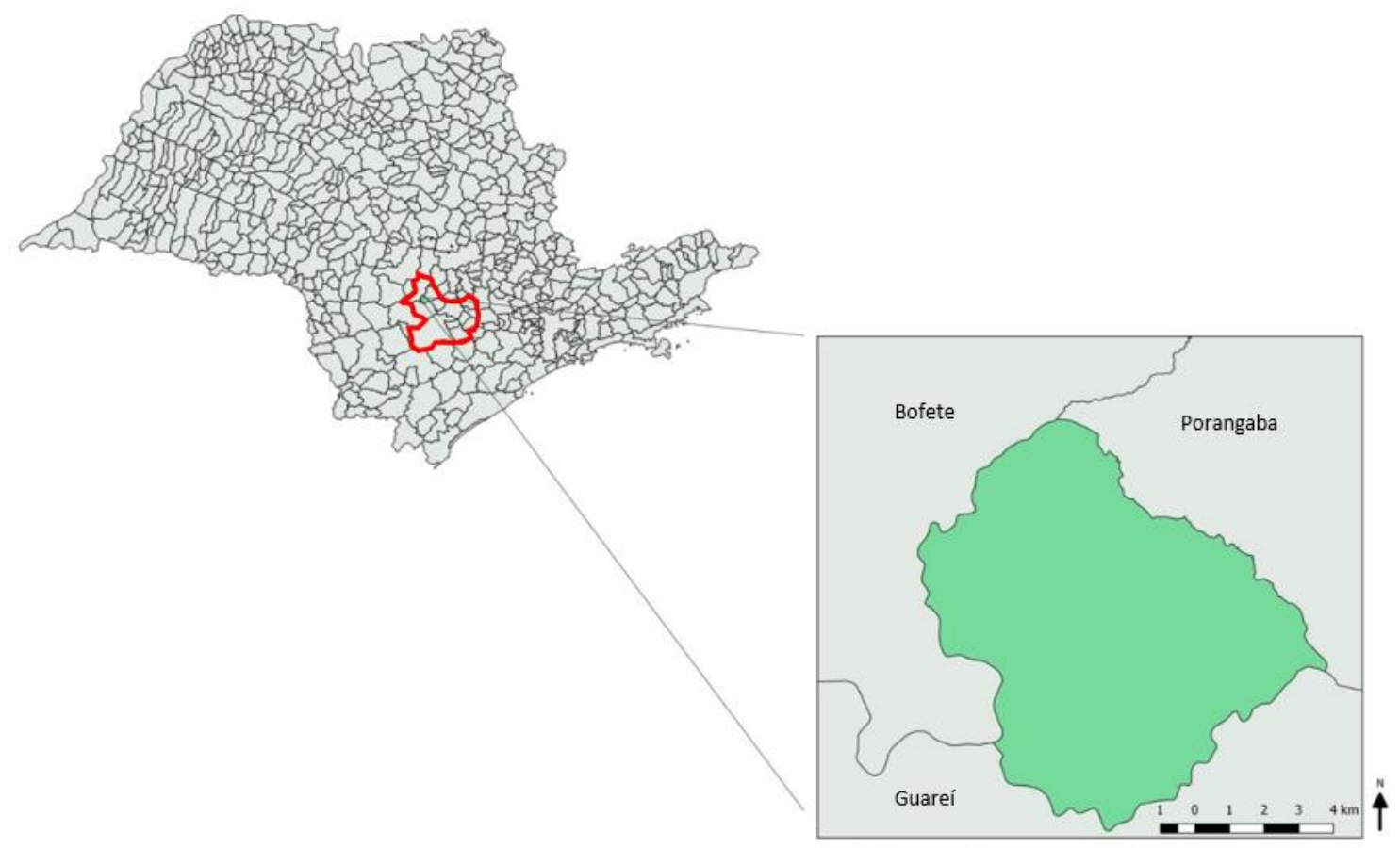

Figura 1: Imagem de localização do polígono representando a área de estudo, o município de Torre de Pedra (SP). Em vermelho, mesorregião de Itapetininga, à qual o município pertence.

A ocupação da região do atual município de Torre de Pedra começou por volta do início do século XX e esteve atrelada a religiosos ligados ao protestantismo (TORRE DE PEDRA, 2018). A vila de Torre de Pedra passou a ser um distrito do município de Porangaba em 1927, sendo anteriormente vinculada ao município de Tatuí (Figura 2). As 
atividades da vila de Torre de Pedra eram essencialmente agropecuárias, sendo que o vilarejo teve um grande pico de desenvolvimento durante a construção da Rodovia Castelo Branco, nos anos 1960 (Figura 3). É possível observar que houve pequeno crescimento da área urbana da vila em comparação com a foto de 1942. Ao fundo, as fotos apresentam o morrete que fica ao lado do Morro Agudo.

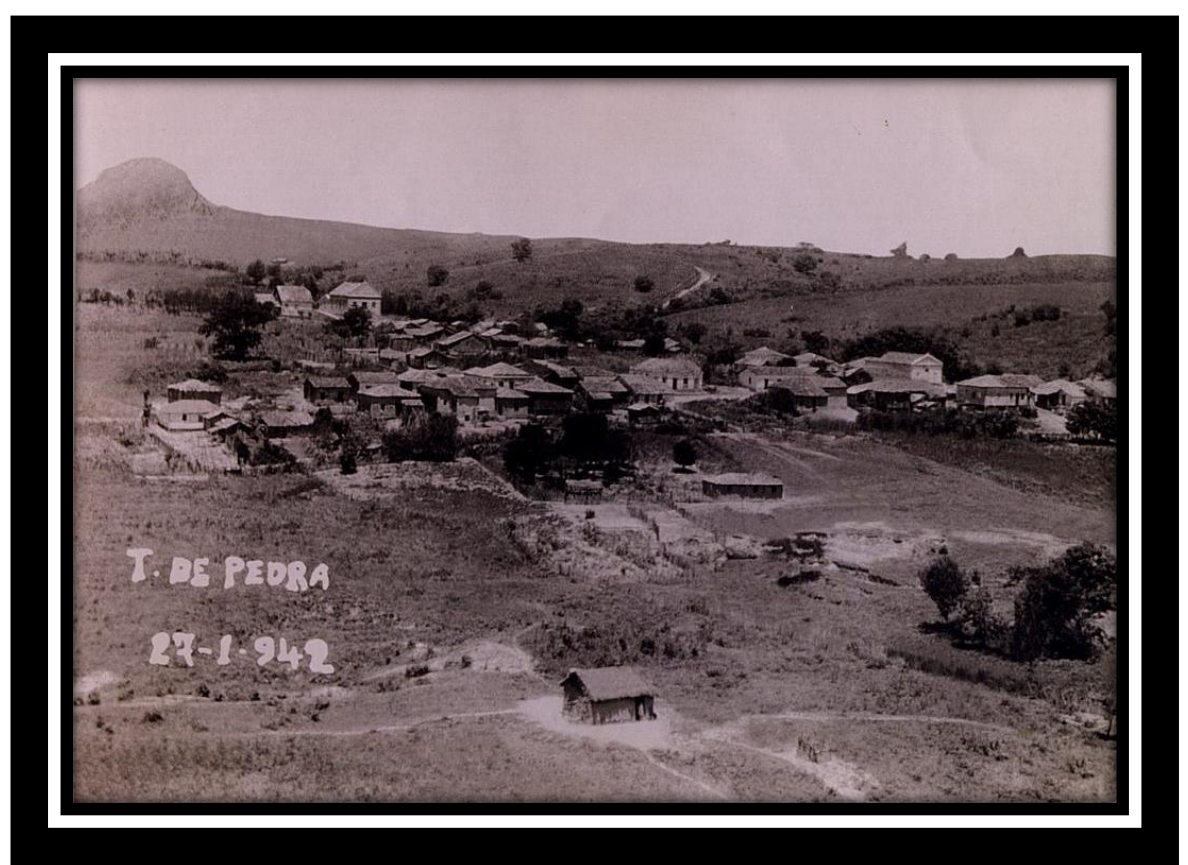

Figura 2: Fotografia da vila de Torre de Pedra em 1942. Fonte: Acervo Público do Estado de São Paulo.

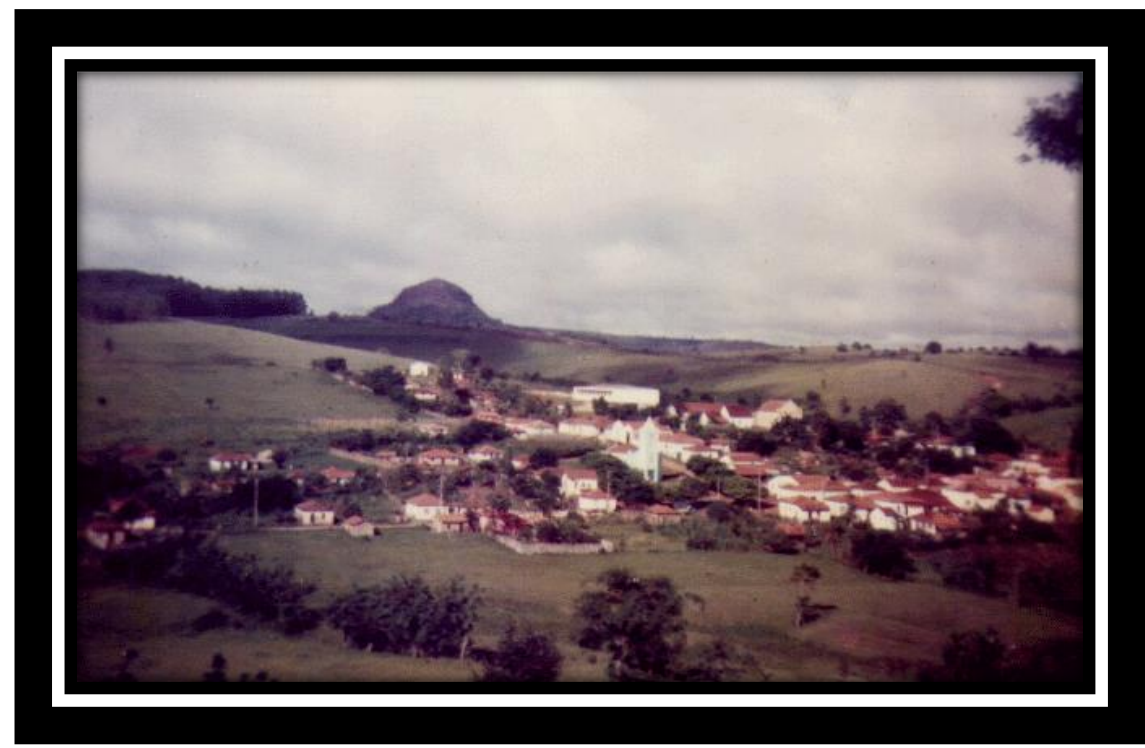

Figura 3: Fotografia da vila de Torre de Pedra em 1972. Fonte: Acervo Público do Estado de São Paulo. 
Torre de Pedra foi alçada ao patamar de município em 1991 pela lei $\mathrm{n}^{\circ} 7664$, de 30 de dezembro de 1991, conforme fluxograma 1 (IBGE, 2018).

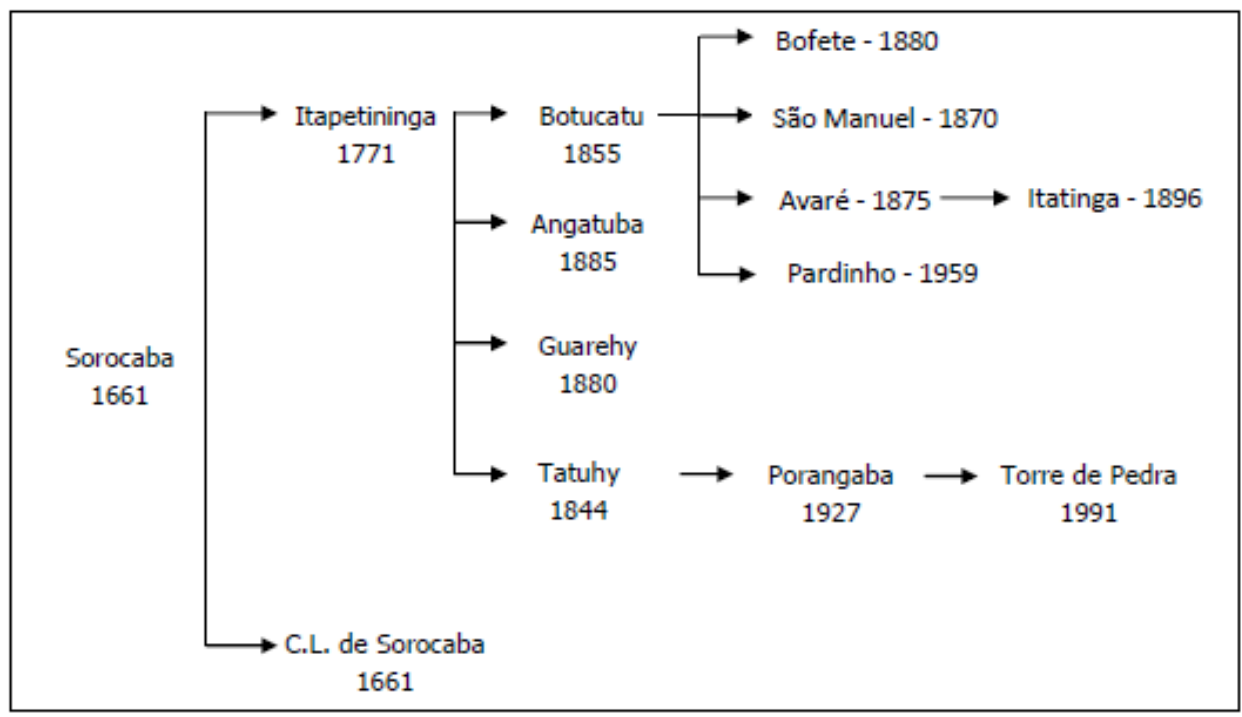

Fluxograma 1: Desmembramento dos municípios que deram origem ao município de Torre de Pedra. Fonte: São Paulo, 2011.

Antes da ocupação por colonizadores, esta região era ocupada por indígenas das etnias Kaingang, Guarani e Oti-xavante. Com o início da expansão da ocupação do território brasileiro para o interior do país, a atividade pecuária pressionou as populações indígenas da região. Contudo, foi a atividade cafeeira que suscitou a ocupação mais sistemática do território, culminando em medidas extremas e violentas para a expulsão dos indígenas. Há relatos de indígenas que resistiram à invasão de suas terras na região, principalmente os Kaingang. No início do século XX, a população indígena já estava parcialmente dizimada e os indígenas remanescentes foram deslocados para territórios indígenas na região (CRUZ, 2006; GRIESE E MELO, 2012).

No relevo da região, destaca-se o morro-testemunho Torre de Pedra (Figura 4). Nesta área, há o contato entre a Depressão Periférica e o relevo de cuestas, sendo portanto uma área relevante para compreender a gênese geomorfológica e dos possíveis usos para locais que se encontram próximos às cuestas. No tocante a vegetação da área de estudo, o local encontra-se em meio a Mata Atlântica, com importantes enclaves de Cerrado.

Em relação às características litológicas dessa região, já foram encontradas rochas do tipo sedimentar de diferentes eras geológicas (arenitos) além de rochas de origem vulcânica, intrusivas e extrusivas (SILVA, 2008), como basaltos. 


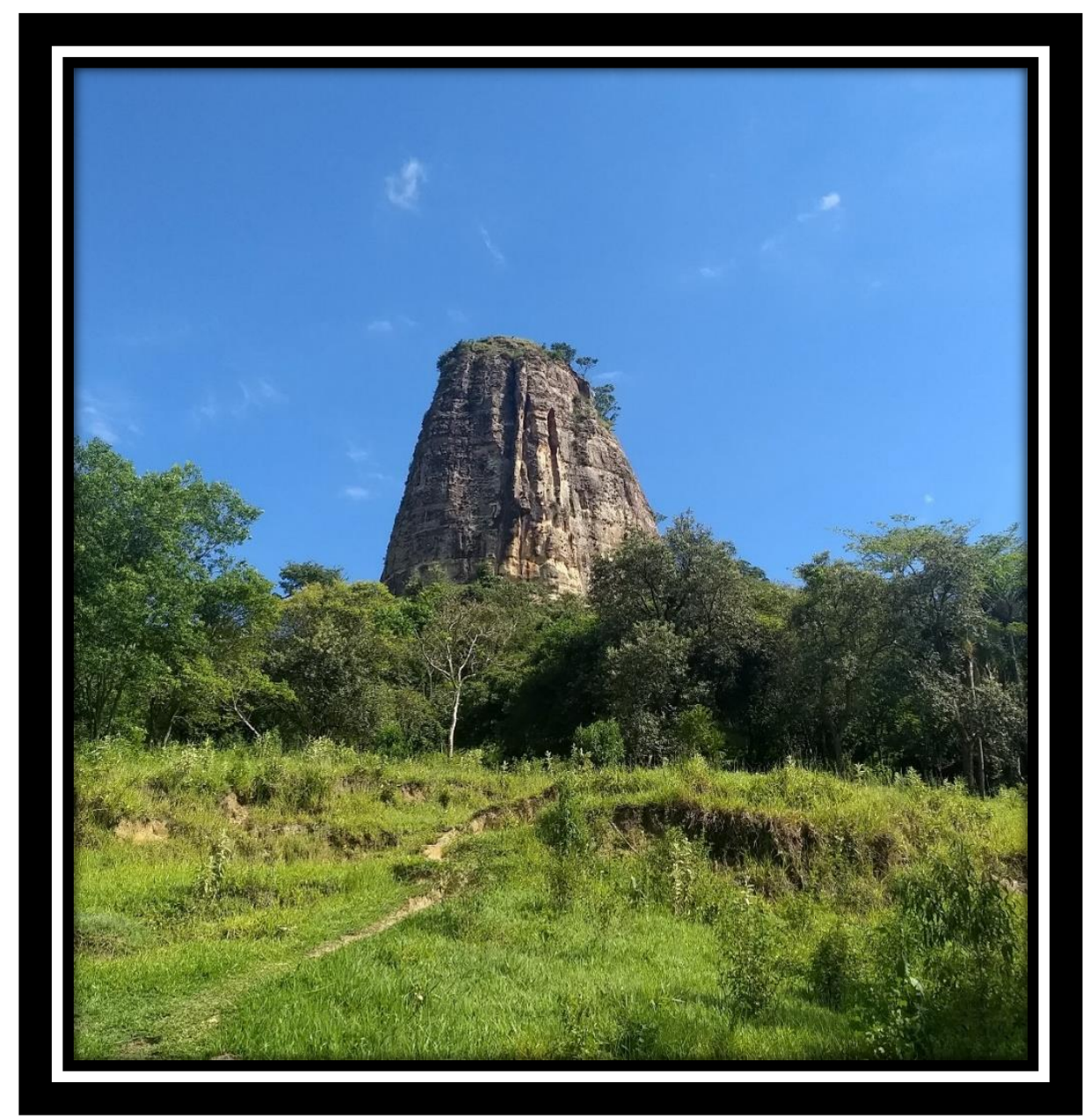

Figura 4: Fotografia da Torre de Pedra, no município de Torre de Pedra (SP). Foto: Jéssica Vieira de Faria, 2018.

A morfogênese da região foi influenciada pela ação de erosão nas bordas da bacia da Depressão Periférica, Bacia do Paraná (AB’SABER, 1949). Esta erosão semi-circular foi denominada por Ab'Saber de circundenudação, dando origem ao relevo de cuestas, geradas nos movimentos cenozóicos (ALMEIDA, 1949).

Ab’Saber (1956) e Almeida (1974) aprofundaram os estudos sobre a geomorfologia do estado de São Paulo e inclusive sobre a origem geomorfológica da área de estudo.

O processo denominado de circundenudação por Ab’Saber (1949) é o responsável pelo rebaixamento das bordas da bacia do Paraná, uma vez que esta bacia encontrava-se elevada em relação à Depressão Periférica. Tal processo erosivo produziu, em suas bordas, as formações de relevo conhecidas como cuestas. De acordo com Almeida (1974) a região conhecida como Cuestas Basálticas, tem altitudes de até 1000 a 1200 metros, 
porém alguns desníveis podem chegar a 400 metros nas serras locais, sendo que sua litologia é basicamente composta por derrames basálticos. (Figura 5)

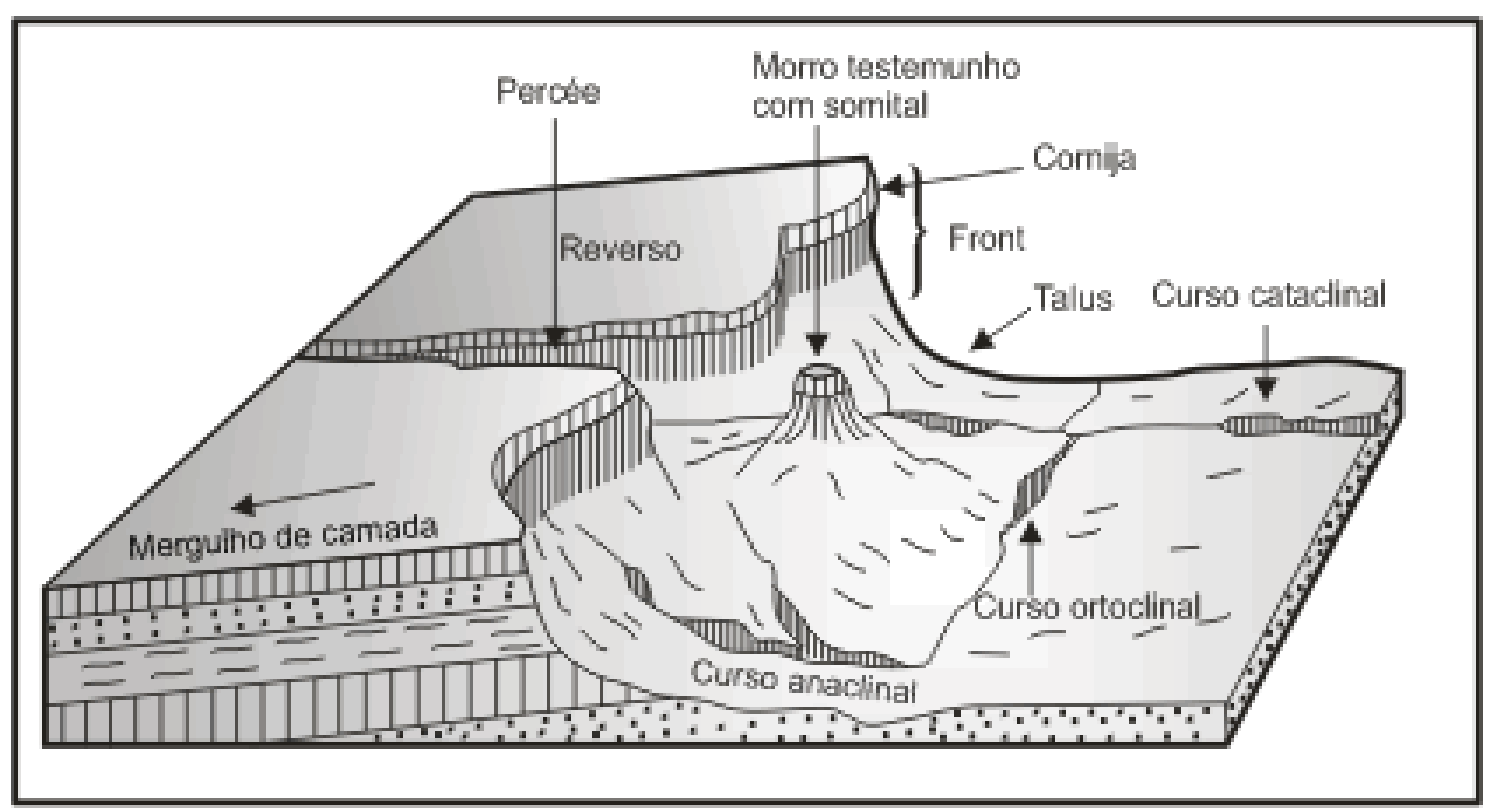

Figura 5: Esquema sobre a formação das cuestas. Fonte: CASSETI, 2005.

Almeida (1974, p. 74), ainda, destaca a presença das estruturas silicificadas no relevo paulista na região de encontro entre os compartimentos Zona do Paranapanema e do Médio Tietê, testemunhas do processo de erosão formador das cuestas (Figuras 6 e 7). Segundo o autor:

Nos municípios de Guareí e Porangaba as divisas das zonas do Paranapanema e Médio Tietê desenvolvem-se numa faixa de campos ornados de altos testemunhos de erosão da cuesta basáltica, de formas bizarras como a Torre de Pedra e o Morro Agudo, ou ainda coroados de derrames basálticos, como os morros existentes nas nascentes do rio Capivari a norte da cidade de Guareí. 


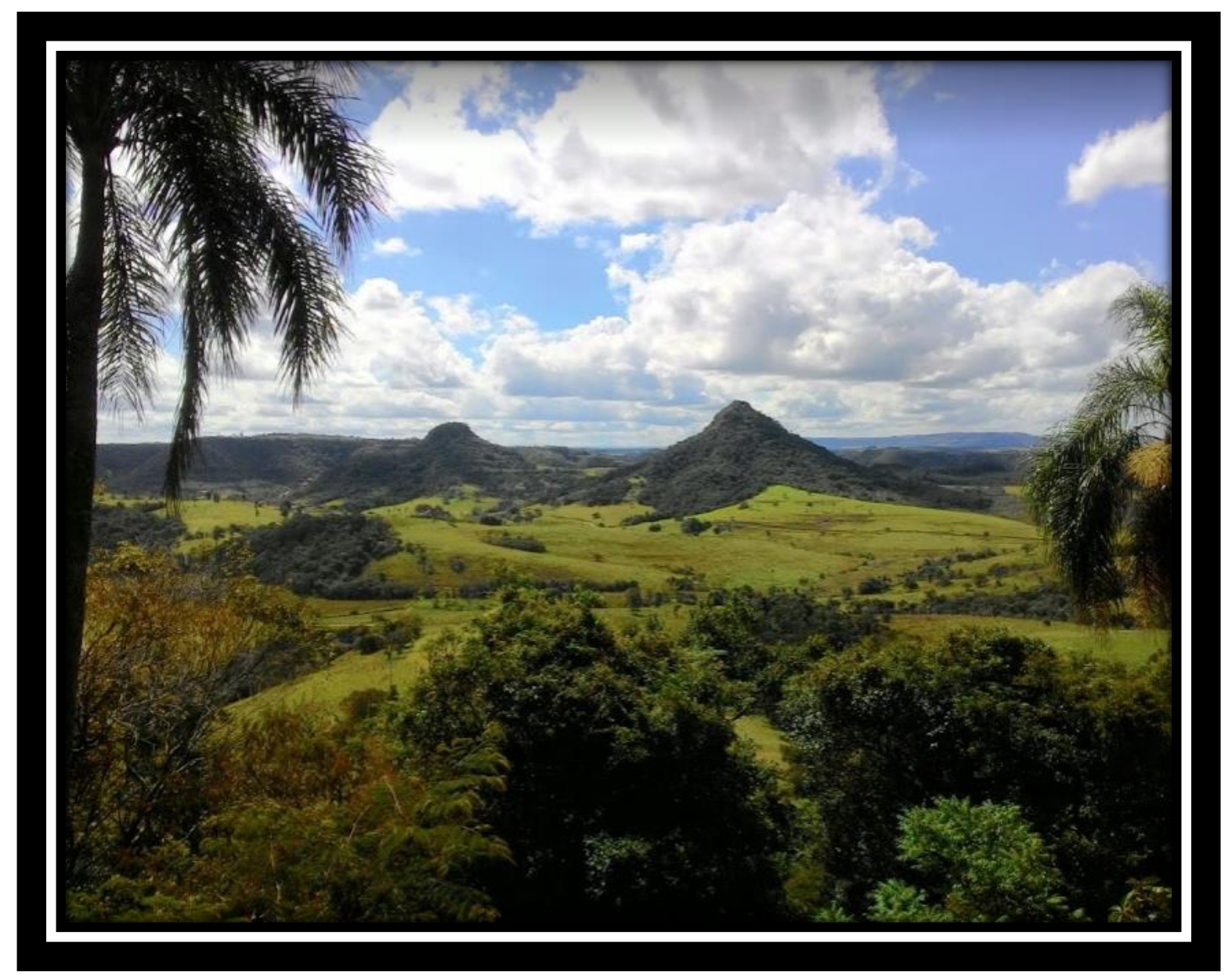

Figura 6: Morro agudo, outra forma do tipo morro-testemunho distante cerca de três quilômetros da Torre de Pedra. Foto: Jéssica Vieira de Faria, 2018.

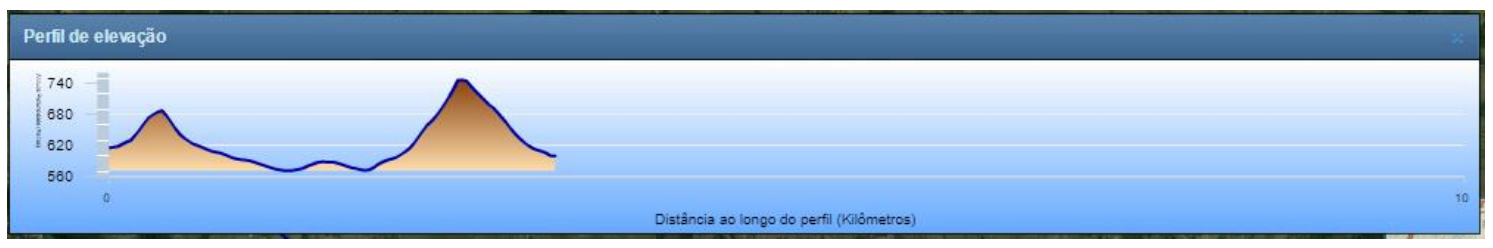

Figura 7: Perfil de elevação do Morro agudo e Torre de Pedra. Fonte: CPRM, 2018.

Durante esse processo, ocorreu a silicificação de determinadas regiões da borda de circundenudação. Como a litologia da região corresponde, em sua maioria, a arenitos das formações Teresina, Pirambóia, Bauru e Botucatu, o arenito silicificado tornou-se mais resistente à erosão, formando os morro-testemunhos, inclusive a Torre de Pedra. A silicificação é definida como cimentação por sílica e diversos fatores influem neste processo, como geomorfologia, clima, temperatura e pH (OLIVEIRA, 2001). Conforme a litoestratigrafia apresentada na figura 8, a litologia da região é muito antiga, pois os arenitos tem formações que remetem aos períodos geológicos Permiano, Triássico e JuroCretáceo. 


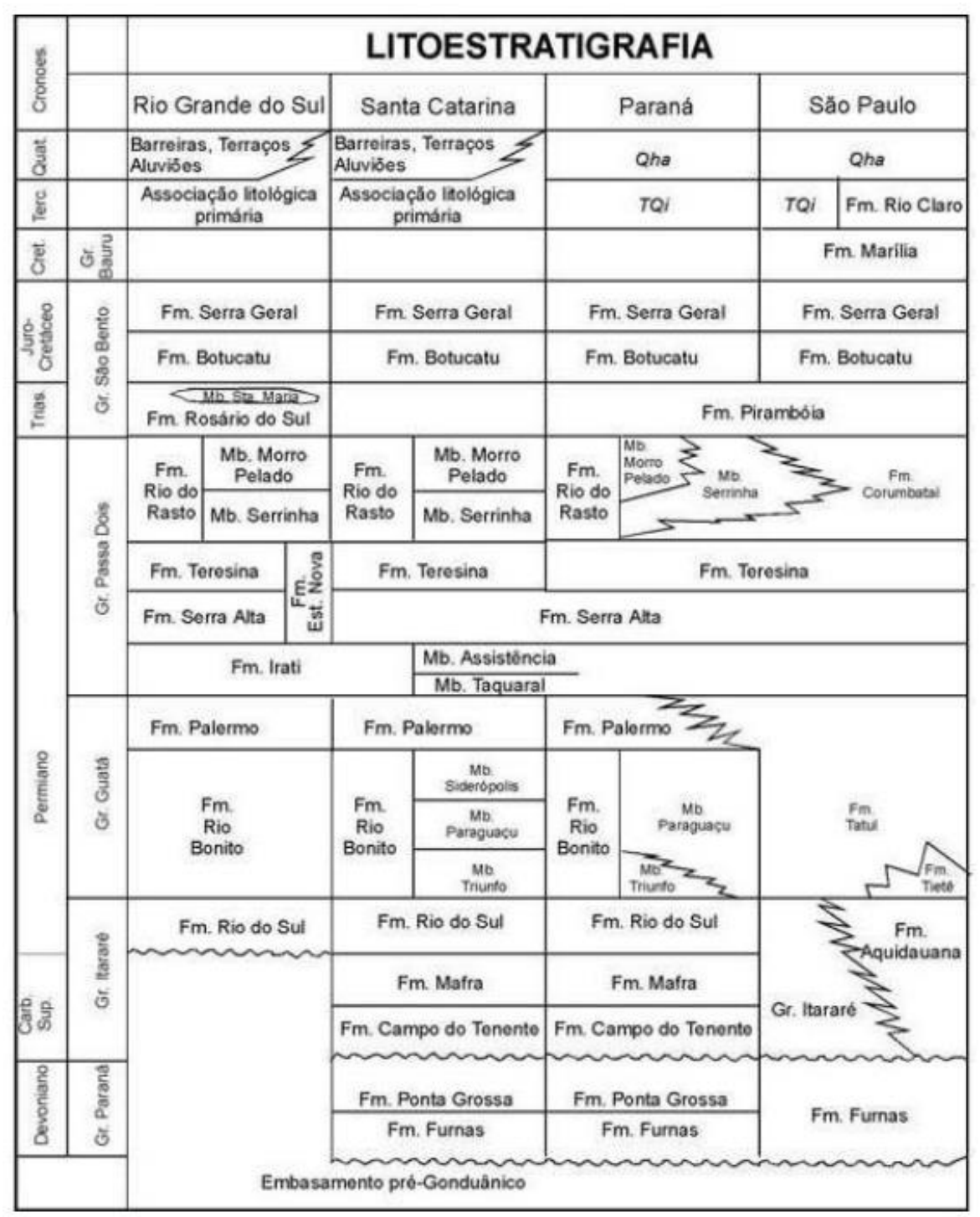

Figura 8: Litoestatigrafia da Bacia do Paraná. Fonte: PEROTTA et al. 2005 apud SÃO PAULO, 2011.

Para Giacomeli et al. (2008, p. 1):

A silicificação, pioneiramente, foi definida como um processo de metassomatismo diagenético, que ocorre basicamente de três maneiras: substituição de rochas por quartzo, chert ou jasperóide; preenchimento de descontinuidades abertas por esses mesmos componentes minerais; e também por concentração mecânica de quartzo a partir de lixiviação de materiais solúveis seguida de recimentação silicosa em algumas situações.

Existem diversas teorias sobre os processos que suscitaram o processo de silicificação nesta região.

Oliveira (2001) destaca as seguintes teorias: 
a- $\quad$ Percolação de águas termais silicosas em fraturas (COIMBRA et al., 1981 apud OLIVEIRA, 2001)

b- Água freática e/ou meteórica que solubilizaria sílica das rochas envolvidas (TRUCKENBRODT, 1997 apud OLIVEIRA, 2001)

c- Dissolução de diminutos fragmentos de quartzo gerados pela abrasão mecânica eólica (TRUCKENBRODT, 1997 apud OLIVEIRA, 2001)

d- $\quad$ Taludes de rochas sedimentares da Bacia do Paraná, expostas ao clima tropical úmido, sofrem cimentação por sílica através da evaporação aliada a capilaridade (VILAR et al., 1986 apud OLIVEIRA, 2001)

Tais teorias acerca da origem do arenito silicificado constituinte da Torre de Pedra baseiam-se na litologia da torre, que possui muitas fraturas verticais que "certamente influenciam na intensidade pontual da silicificação, seja intempérica ou por percolação de fluidos hidrotermais" (OLIVEIRA, 2001) e a localização da Torre de Pedra em meio ao Aquífero Guarani.

No tocante à geomorfologia da área de estudo, com a leitura do Mapa Geomorfológico do Estado de São Paulo (ROSS E MOROZ, 1997), observou-se que a área de estudo encontra-se na morfoestrutura Bacia Sedimentar do Paraná. Dentro desta, na região da morfoescultura Depressão do Paranapanema. A Depressão do Paranapanema é composta por colinas de topos convexos, com altitudes entre $600 \mathrm{~m}$ e $700 \mathrm{~m}$ e declividades de entre 10 e $20 \%$. Sua litologia predominante são arenitos, enquanto a pedologia constitui-se em areais quartzosas e argissolos vermelho-amarelos. Ainda, encontra-se nessa região colinas médias e morrotes alongados e espigões. Almeida (1974) afirma que essa região apresenta diáclases orientadas a NE e NW.

A Divisão Geomorfológica do Estado de São Paulo proposta pelo Instituto de Pesquisas Tecnológicas em 1981 apresenta uma análise semelhante, porém com descrições e nomenclatura diversas. Enquanto em Ross e Moroz (1997) a área estudada é descrita como colinas de topos convexos, a área de estudo deste trabalho, no mapa do IPT de 1981, está na transição entre as formas de relevo 234 e 241, localizada no limite de transição de relevos não escarpados.

Estas formas de relevo são descritas como:

II - Relevos de degradação, em planaltos dissecados.

234 - Morrotes alongados e espigões (declividades médias a altas, acima de 15\%, e amplitudes inferiores a $100 \mathrm{~m})$ 
241 - Morros arredondados (declividades médias a altas, acima de 15\%, e amplitudes entre $100 \mathrm{~m}$ e $300 \mathrm{~m}$ )

Nos dois mapas, os táxons mais gerais são os mesmos: Depressão Periférica (Morfoestrutura) e Zona do Paranapanema (Morfoescultura).

O potencial turístico de uma parte do município de Torre de Pedra já foi avaliado em outros estudos (FARIA, 2014), contudo, para uma análise que visa abranger o município todo, é necessário considerar a influência climática na atividade turística na região. O clima do município é do tipo Cwa (tropical de altitude), com pluviosidade anual média de 1354 mm (UNICAMP, 2016) e chuvas concentradas nos meses do verão (CPTEC/INPE, 2018). Por isso, é importante que o programa de turismo do município incentive a visitação ao local nos meses de abril a outubro.

A área de estudo encontra-se totalmente inserida dentro de uma APA (Área de Proteção Ambiental), sendo, portanto, submetida aos regulamentos específicos deste tipo de unidade de conservação. A APA que abrange a área de estudo é a APA Corumbataí, Botucatu, Tejupá, estabelecida pelo decreto Decreto Estadual No 20,960, de 8 de junho de 1983. Esta APA é composta por três perímetros e o município de Torre de Pedra está incluso no perímetro Botucatu. As justificativas para o estabelecimento da APA nesta região foram: a preservação da vegetação e fauna remanescentes da Mata Atlântica e transição para o Cerrado que existe na região (SÃO PAULO, 1983) e garantir a recarga de águas do Aquífero Guarani (Figura 9).

A inserção da área de estudo em uma APA mudou a perspectiva do trabalho, uma vez que há legislações e regulações que foram estudadas e respeitadas acerca desta situação, além do plano de manejo da APA, realizado em 2011. 


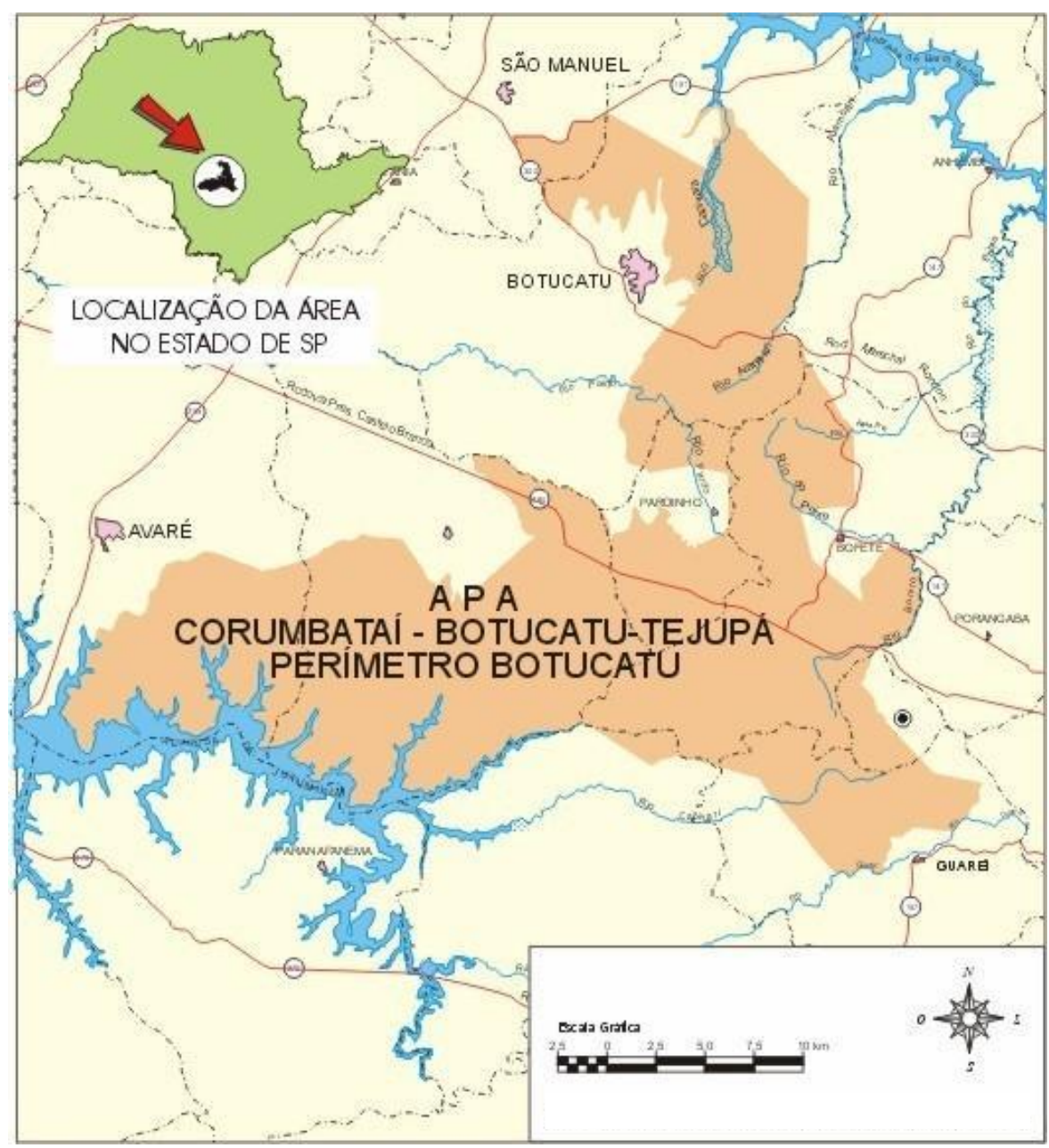

Figura 9: Polígono representativo da APA Corumbataí, Botucatu, Tejupá, Perímetro Botucatu. Fonte: S.O.S. Cuesta de Botucatu, 2016.

O desenvolvimento de atividades econômicas dentro das regiões de APA deve ser monitorado para garantir a preservação ambiental da área, incluindo a atividade turística. Dessa forma, o turismo surge como alternativa para desenvolver atividades econômicas em APAs de modo a preservá-las. Podem ser citados como exemplos de atividades turísticas em APAs do estado de São Paulo: Campos do Jordão, Pedra do Baú (São Bento do Sapucaí), Morro do Cuscuzeiro (Analândia). 


\section{FUNDAMENTAÇÃO TEÓRICO-METODOLÓGICA}

A fundamentação teórico-metodológica foi dividida em três partes: a primeira tratou das unidades de paisagem e suas múltiplas definições (3.1). A segunda parte buscou conceituar os benefícios ecossistêmicos (3.2), enquanto a terceira parte abordou o geoturismo e conceitos afins (3.3).

\subsection{Unidades de paisagem}

A definição do conceito de paisagem na Geografia é uma discussão longa, que abrange todas as vertentes da ciência geográfica. Nos estudos específicos da paisagem para fins de planejamento e sob a perspectiva da Geografia Física, Ross (1992) faz uma análise histórica do conceito, conforme quadro a seguir:

Quadro 1: Definições de paisagem sob abordagem sistêmica. Adaptado de Ross, 1992.

\begin{tabular}{|c|c|}
\hline Autor, ano & Concepção da paisagem \\
\hline Bertrand, 1971 & $\begin{array}{l}\text { Paisagem como certa porção do espaço, resultante da interação } \\
\text { dinâmica e instável de atributos físicos, biológicos e antrópicos, que, } \\
\text { reagindo dialeticamente uns sobre os outros, fazem dela um conjunto } \\
\text { único e indissociável }\end{array}$ \\
\hline $\begin{array}{l}\text { Morin (1977) e } \\
\text { Christofoletti (1979) }\end{array}$ & $\begin{array}{l}\text { A configuração da paisagem depende dos elementos, relações, } \\
\text { atributos, entradas (inputs) e saídas do sistema (output) considerando uma } \\
\text { análise espaço-temporal. }\end{array}$ \\
\hline Rodriguez, 1994 & $\begin{array}{l}\text { A análise sistêmica se baseia no conceito de paisagem com um } \\
\text { "todo sistêmico" em que se combinam a natureza, a economia, a sociedade } \\
\text { e a cultura, em um amplo contexto de inúmeras variáveis que buscam } \\
\text { representar a relação da natureza como um sistema e dela com o homem. }\end{array}$ \\
\hline Christofoletti (1998) & $\begin{array}{l}\text { Atribui à paisagem a concepção de conceito chave da Geografia } \\
\text { que possibilita a compreensão do espaço como um sistema ambiental, } \\
\text { físico e socioeconômico, com estruturação, funcionamento e dinâmica dos } \\
\text { elementos físicos, biogeográficos, sociais e econômicos. }\end{array}$ \\
\hline
\end{tabular}




\begin{tabular}{|l|r|}
\hline $\begin{array}{l}\text { Bolós apud Guerra e } \\
\text { Marçal (2006) }\end{array}$ & $\begin{array}{r}\text { A paisagem em sua abordagem sistêmica e complexa será sempre } \\
\text { dinâmica e compreendida como o somatório das inter-relações entre os } \\
\text { elementos físicos e biológicos que formam a natureza mais as intervenções } \\
\text { da sociedade no tempo e no espaço em constante transformação. }\end{array}$ \\
\hline
\end{tabular}

O conceito de paisagem adotado nesta pesquisa é a definição de Bertrand (2004, p. 141):

A paisagem não é a simples adição de elementos geográficos disparatados. É, em uma determinada porção do espaço, o resultado da combinação dinâmica, portanto instável, de elementos físicos, biológicos e antrópicos que, reagindo dialeticamente uns sobre os outros, fazem da paisagem um conjunto único e indissociável, em perpétua evolução.

Para Monteiro (2000), os objetivos centrais da análise do pesquisador são responsáveis pela definição do nível de resolução da paisagem, sendo ela o resultado de uma integração dinâmica e instável de elementos de suporte e cobertura (físicos, biológicos e antrópicos), expressa em partes delimitáveis infinitamente, mas individualizadas através das relações entre elas, que organizam um todo complexo (sistema) verdadeiro conjunto solidário em perpétua evolução.

O conceito de unidade de paisagem também é variável. Para alguns autores, como Martinelli e Pedrotti (2001), a unidade de paisagem é uma metodologia para cartografia ambiental - uma abordagem que trata da interação entre a cartografia e elementos socioambientais, ou seja, uma maneira de dimensionar cartograficamente as relações entre sociedade e ambiente.

Também há propostas de análise que consideram a vegetação e sua dinâmica, além das respectivas mudanças no espaço produzidas pelas relações sociais. Nesta definição, paisagem é o que vemos diante de nós, uma realidade visível. Neste contexto de cartografia ambiental, a unidade de paisagem é uma categoria de síntese. (ROSS, 1990; MARTINELLI E PEDROTTI, 2001). Para Mateo-Rodriguez et al. (2007), as unidades de paisagens são fundamentadas no sistema de relações internas, considerando-se variáveis como: relevo, pedologia, uso do solo e cobertura vegetal.

Para Bertrand (2004), a definição de unidade de paisagem se mescla à de paisagem. A unidade de paisagem é o resultado da conjunção de fatores distintos: fatores 
geográficos, como fatores bióticos, abióticos e antrópicos (geologia, relevo, clima, vegetação, sociedade). Essa categoria exige raciocínio de síntese. Bertrand (2004) apresenta uma sequência bem delimitada de hierarquias para a delimitação de unidades de paisagem (tabela 1$)$.

\begin{tabular}{|c|c|c|c|c|c|c|c|}
\hline \multirow{2}{*}{$\begin{array}{c}\text { UNIDADES DA } \\
\text { PAISAGEM }\end{array}$} & \multirow[b]{2}{*}{$\begin{array}{c}\text { ESCALA } \\
\text { TEMPORO- } \\
\text { ESPACIAL (A. } \\
\text { CAILEUX J. } \\
\text { TRICART) }\end{array}$} & \multirow{2}{*}{$\begin{array}{l}\text { EXEMPLO TOMADO NUMA } \\
\text { MESMA SÉRIE DE } \\
\text { PAISAGEM }\end{array}$} & \multicolumn{5}{|c|}{ UNIDADES ELEMENTARES } \\
\hline & & & RELEVO (1) & Clima (2) & BotínICA & BIOGEOGRAFL & $\begin{array}{c}\text { UNIDADE } \\
\text { TRABALHADA } \\
\text { PELO HOMEM } \\
\text { (3) }\end{array}$ \\
\hline ZONA & $\begin{array}{c}\text { G I grandeza } \\
\text { G. I }\end{array}$ & Temperada & & Zonal & & Bioma & Zona \\
\hline DOMINIO & G. II & Cantábrico & $\begin{array}{l}\text { Dominio } \\
\text { estrutural }\end{array}$ & Regional & & & $\begin{array}{c}\text { Domínio } \\
\text { Região }\end{array}$ \\
\hline $\begin{array}{c}\text { REGIÅO } \\
\text { NATURAL }\end{array}$ & G. III-IV & Picos da Europa & $\begin{array}{l}\text { Regià̀o } \\
\text { estrutural }\end{array}$ & & $\begin{array}{l}\text { Andar } \\
\text { Série }\end{array}$ & & $\begin{array}{c}\text { Quarteirăo rural } \\
\text { ou urbano }\end{array}$ \\
\hline GEOSSISTEMA & G. IV-V & $\begin{array}{c}\text { Atlântico Montanhês } \\
\text { (calcário sombreado com } \\
\text { faia higrófila a Asperula } \\
\text { odorata em "terra fusca") }\end{array}$ & $\begin{array}{l}\text { Unidade } \\
\text { estrutural }\end{array}$ & local & & $\begin{array}{c}\text { Zona } \\
\text { equipotencial }\end{array}$ & \\
\hline GEOFACIES & G. VI & $\begin{array}{c}\text { Prado de ceifa com } \\
\text { Molinio-Armenatheretea } \\
\text { em solo lixiviado } \\
\text { hidromórfico formado em } \\
\text { depósito morâinico }\end{array}$ & & & $\begin{array}{l}\text { Estádio } \\
\text { Agrupamen- } \\
\text { to }\end{array}$ & & $\begin{array}{l}\text { Exploração ou } \\
\text { quarteiråo } \\
\text { parcelado } \\
\text { (pequena ilha } \\
\text { ou cidade) }\end{array}$ \\
\hline GEÓTOPO & G. VII & $\begin{array}{l}\text { "Lapiés" de dissolução } \\
\text { com Aspidium lonchitis } \\
\text { em microsolo úmido } \\
\text { carbonatado em bolsas }\end{array}$ & & Microclima & & $\begin{array}{l}\text { Biótopo } \\
\text { Biocenose }\end{array}$ & $\begin{array}{l}\text { Parcela (casa } \\
\text { em cidade) }\end{array}$ \\
\hline
\end{tabular}

NOTA: As correspondências entre as unidades são muito aproximadas e dadas somente a título de exemplo.

1 - conforme A. Cailleux, J. Tricart e G. Viers; 2 - conforme M. Sorre; 3 - conforme R. Brunet.

Tabela 01: Definiçõoes de unidades de paisagem segundo G. Bertrand. Bertrand, 2004.

Para Bertand (2004, p. 151):

Na escala grande $1 / 20.000$, pode-se facilmente cartografar os geofácies no interior dos geosistemas. A cor ou a variação na cor de cada geosistemas indica a situação dinâmica em relação ao clímax (geofáciesclimax em azul, geofácies degradado em amarelo ou em vermelho).

Este autor ressalta que é impossível existir um sistema que tenha limites próprios e estritamente delimitados na natureza. O pesquisador é responsável por essa delimitação, que serve como ferramenta de estudo dessa realidade da paisagem.

A unidade de paisagem geossistema é caracterizado por elementos geográficos e sistêmicos. Como elementos geográficos, temos: antrópicos (impactos das sociedades 
sobre o ambiente), abióticos (rocha, ar e água); bióticos (animais, vegetais e solos) (figura 10). Como sistêmicos considera três conceitos: espacial, natural e antrópico. (PISSINATI E ARCHELA, 2009):

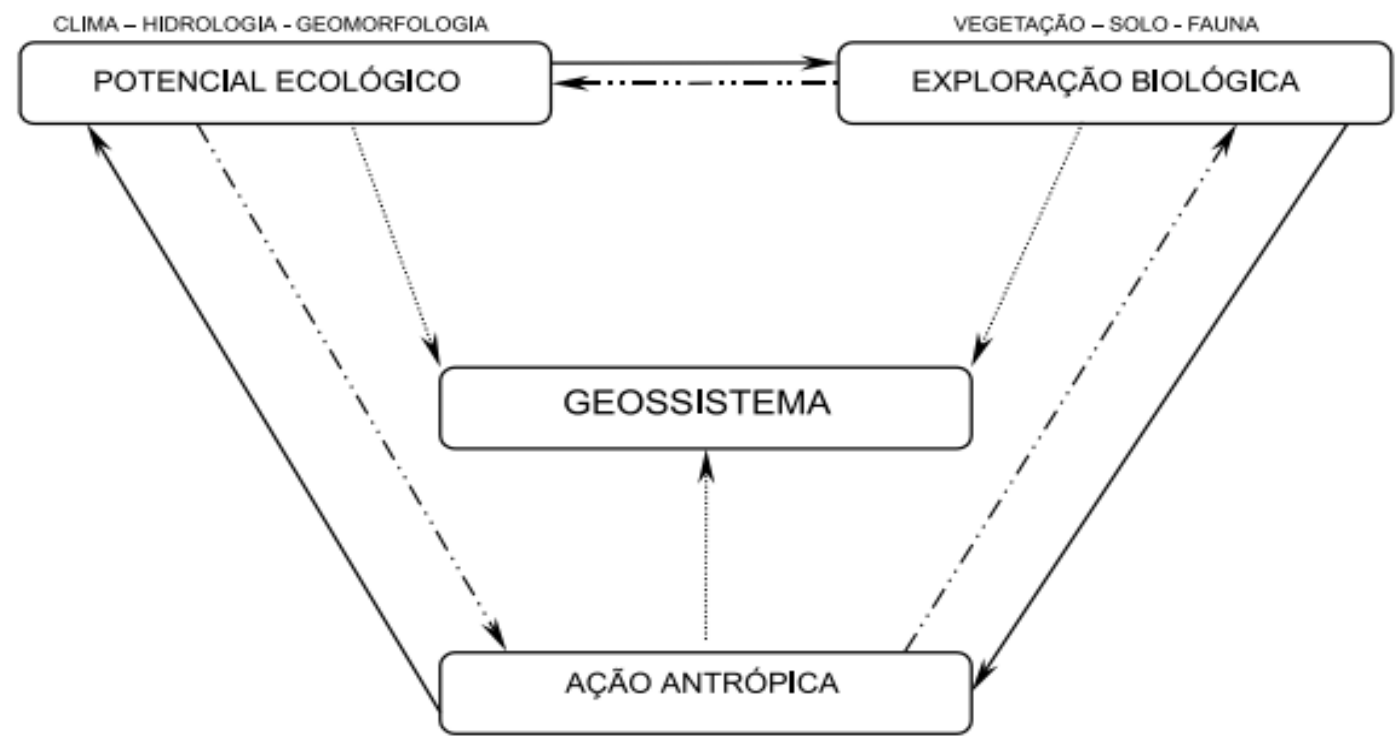

Figura 10: Definição de Geossistema. Fonte: Bertrand, 2004.

Segundo Pissinati e Archela, (2009, p. 11):

Em síntese, pode-se considerar o geossistema como um complexo formado e as relações naturais existentes entre os elementos bióticos e abióticos; o território é a forma de uso político, social e econômico do espaço geográfico; e a paisagem é expressão cultural, manifesta através da apropriação, da utilização e do significado que é atribuído aos elementos do geossistema, pela comunidade local.

Para Mateo-Rodriguez (2000), os sistemas de paisagem podem ser classificados de diversas formas, sendo que as principais abordagens de análise são: estrutural, funcional, dinâmica-evolutiva, informacional e histórico-antropogênico. A análise da paisagem proposta nesse trabalho é a abordagem funcional. Este tipo de análise baseiase na gênese, funcionamento, estrutura e relações funcionais da paisagem. Para isso, estuda-se a função geoecológica, formas de configuração paisagística e processos geoecológicos impactantes e degradantes. O estudo da paisagem, segundo MateoRodriguez et al. (2007), nas pesquisas geoecológicas, busca conhecer e explicar as 
regularidades das estruturas e funcionamento das paisagens. Além de estudar suas propriedades, dinâmica, história de formação e transformação, estuda também a autoregulação e integração entre as paisagens.

Outro autor que se debruça sobre os estudos das paisagens é Nucci (1998). O autor considera o planejamento da paisagem como contribuição ecológica e de design para o planejamento do espaço, procurando regulamentar o uso do solo e áreas verdes, salvaguardando a capacidade dos ecossistemas e o potencial recreativo da paisagem. Dentre as ações possíveis dentro dessa perspectiva, há: o manejo da paisagem (área rural); o planejamento de espaços livres (cidades) e a proteção da natureza.

Delpoux (1974) adota o uso do termo paisagem ao invés de ecossistema para abranger a dimensão espacial dos fenômenos, representáveis através dos mapas. Segundo $\mathrm{o}$ autor, os componentes da paisagem são suporte e cobertura. $\mathrm{O}$ suporte refere-se a microrelevos, clima, morfogênese, litologia, etc., enquanto a cobertura refere-se a manifestação desses parâmetros. Segundo, o autor, a paisagem corresponde " [...] a entidade espacial correspondente à soma de um tipo geomorfológico e de uma cobertura no sentido mais amplo deste termo (da floresta à aglomeração e à zona industrial passando pelas culturas ou superfícies aquáticas)” (DELPOUX, 1974, p. 5). Além disso, o autor classifica as paisagens como equilibradas, exportadoras ou consumidoras de energia.

A análise das paisagens sob a perspectiva sistêmica, baseado em Bertalanffy (1973), ocorreu, inicialmente, correlacionando os conceitos de paisagem e organismo (VALE, 2012). O Geossistema, no decorrer dos estudos da paisagem, é o conceito que sintetiza a integração da Teoria Geral dos Sistemas à Geografia Física.

Jean Tricart (1977), na obra Ecodinâmica, apresenta uma abordagem baseada na teoria sistêmica ao propor a delimitação e análise de unidades territoriais a partir das relações entre os diferentes elementos que as compunham, inclusive considerando a circulação de energia e matéria dentro dessas unidades.

Partindo dessa perspectiva, o autor define três categorias de meios, com suas respectivas definições:

1- Meios estáveis (pedogênese predominante);

2- Meios intergrade (situação intermediária de transição);

3- Meios fortemente instáveis (morfogênese predominante) (TRICART, 1977).

A pesquisa levou em conta fatores abióticos e fatores associados ao uso do solo em escala de maior detalhe. Assim, a hierarquização proposta leva em consideração esses 
fatores no nível de maior detalhamento. Mateo-Rodriguez et al. (2007) apresentam um quadro comparativo de classificação das unidades de paisagem sob a perspectiva de diferentes escolas de estudo da paisagem (Quadro 2). A classificação desta pesquisa se aproxima do sistema de classificação geomorfológica.

Quadro 2: Quadro comparativo de classificação de unidades de paisagem. Fonte: Adaptado de MATEO-RODRIGUEZ et al., 2007.

\begin{tabular}{|c|c|c|c|c|}
\hline \multirow[t]{2}{*}{ Nível } & \multicolumn{3}{|c|}{$\begin{array}{l}\text { SISTEMA DE CLASSIFICAÇÃO GEOMORFOLÓGICA DO } \\
\text { I.T.C. }\end{array}$} & \multirow[t]{2}{*}{$\begin{array}{r}\text { Classificação } \\
\text { fisiográfica }\end{array}$} \\
\hline & Nível & $\begin{array}{c}\text { Características } \\
\text { principais }\end{array}$ & Escala & \\
\hline 1 & $\begin{array}{c}\text { Província } \\
\text { geomorfológica }\end{array}$ & $\begin{array}{c}\text { Altamente } \\
\text { generalizadas } \\
\text { (mais } \\
\text { importante é a } \\
\text { gênese e a } \\
\text { litologia) }\end{array}$ & $1: 1.250 .000$ & $\begin{array}{l}\text { Província } \\
\text { fisiográfica }\end{array}$ \\
\hline 2 & $\begin{array}{c}\text { Unidade } \\
\text { geomorfológica } \\
\text { principal }\end{array}$ & $\begin{array}{c}\text { Generalizada } \\
\text { moderadamente } \\
\text { (relevo, litologia } \\
\text { e gênese são os } \\
\text { principais } \\
\text { critérios de } \\
\text { classificação) }\end{array}$ & $1: 1.250 .000$ & $\begin{array}{l}\text { Unidade } \\
\text { fisiográfica } \\
\text { principal }\end{array}$ \\
\hline 3 & $\begin{array}{c}\text { Unidade } \\
\text { geomorfológica }\end{array}$ & $\begin{array}{l}\text { Generalização } \\
\text { menor (Critérios } \\
\text { principais são o } \\
\text { relevo, a } \\
\text { litologia e a } \\
\text { gênese) }\end{array}$ & 1:500.00 & $\begin{array}{c}\text { Unidade } \\
\text { fisiográfica } \\
\text { detalhada }\end{array}$ \\
\hline 4 & $\begin{array}{c}\text { Detalhe } \\
\text { geomorfológico }\end{array}$ & $\begin{array}{c}\text { Não se } \\
\text { generaliza } \\
\text { (Critério } \\
\text { fundamental de } \\
\text { classificação é o } \\
\text { relevo) }\end{array}$ & 1:10.000 & $\begin{array}{l}\text { Elemento } \\
\text { fisiográfico }\end{array}$ \\
\hline
\end{tabular}




\subsection{Benefícios ecossistêmicos}

Os benefícios ecossistêmicos são indicadores das funções e dinâmicas de cada unidade de paisagem delimitada.

Destaca-se a diferenciação entre três conceitos: ecosystem service, ecosystem function e landscape function. Os ecosystem services ${ }^{1}$ (ES), ou benefícios ${ }^{2}$ ecossistêmicos, são benefícios fornecidos à sociedade pelos ecossistemas e seu funcionamento adequado, como: água potável, decomposição da matéria orgânica, créditos de carbono, emissão de oxigênio para atmosfera, entre outros. Esses benefícios podem ser mensurados e justificam a preservação de áreas de interesse social para além da manutenção do habitat de espécies de fauna e flora. É importante considerar os ES para tomada de decisões. Podem ser classificadas como: fornecimento (produção de alimentos e água potável); regulação (como controle do clima); suporte (como ciclo da polinização) e cultural (como benefícios recreativos). (TÁVORA E TURETTA, 2016)

Por outro lado, landscape function ${ }^{3}$ (LF), apesar de bem semelhante a benefício ecossistêmico, corresponde aos benefícios que não necessariamente tem algum valor para a sociedade. Ou seja, seus benefícios seriam sobretudo relacionados ao equilíbrio de sistemas naturais. A diferença entre landscape function e ecosystem function ${ }^{4}$ (EF) seria a escala: a LF é heterogênea e em escala de menor detalhe, enquanto a EF é em escala de detalhe e abrange regiões mais homogêneas (GROOT E HEIN apud TÁVORA E TURETTA, 2016). Willemen et al. (2008), contudo, definem landscape function (LF) "as the capacity of a landscape to provide goods and services to society"5 (p. 34). Bastian (2000) dá a seguinte definição: "Natural potentials/landscape functions characterize the capability and usability of a landscape in a broad sense"6.

Como não trata da landscape function como ligada a sociedade, e sim em amplo sentido, esse trecho converge com o conceito de landscape function em Távora e Turetta (2016). Nesta pesquisa adotou-se a concepção de abiotic ecosystem services ${ }^{7}$ (ver fluxograma 2, de GRAY et al., 2013).

\footnotetext{
${ }^{2}$ Ecosystem service serão livremente traduzidos como benefícios ecossistêmicos.

${ }^{3}$ Landscape function serão livremente traduzidos como funções das paisagens.

${ }^{4}$ Ecosystem function serão livremente traduzidos como funções ecossistêmicas.

${ }^{5}$ Tradução livre: "a capacidade que uma paisagem tem de fornecer bens e serviços a sociedade"

${ }^{6}$ Tradução livre: "Funções das paisagens/potencial natural caracteriza a capacidade e uso de uma paisagem em um amplo sentido"

${ }^{7}$ Abiotic ecosystem services serão livremente traduzidos como benefícios ecossistêmicos de fatores abióticos
} 
Regulating

1. Atmospheric and oceanic processes (e.g. dynamic circulations; atmospheric chemistry; air quality \& climate regulation; hydrological cycle).

2. Terrestrial processes (e.g. rock cycle; carbon \& other biogeochemical cycles; carbon sequestration, storage \& climate regulation; geomorphological processes; natural hazard regulation; erosion regulation).

3. Flood regulation (e.g. infiltration; barrier islands, river levees, sand dunes, floodplains).

4. Water quality regulation (e.g. soil and rock as natural filters).

\begin{tabular}{|c|c|c|}
\hline $\begin{array}{l}\text { Supporting } \\
\text { 5. Soil processes (e.g. weathering; } \\
\text { soil profile development) and } \\
\text { soil as a growing medium. } \\
\text { 6. Habitat provision (e.g. dynamic } \\
\text { habitats, caves, limestone } \\
\text { pavements, cliffs, saltmarshes). } \\
\text { 7. Land \& water as a platform for } \\
\text { human activity (e.g. building } \\
\text { land, waves, tides). } \\
\text { 8. Burial and storage (e.g. human } \\
\text { and animal burial; municipal } \\
\text { landfill; radioactive waste } \\
\text { storage; oil \& gas reservoirs; } \\
\text { carbon capture \& storage; water } \\
\text { storage in aquifers,, lakes, } \\
\text { glaciers, reservoirs). }\end{array}$ & $\begin{array}{l}\text { ABIOTIC } \\
\text { ECOSYSTEM } \\
\text { SERVICES }\end{array}$ & $\begin{array}{l}\text { Cultural } \\
\text { 16. Environmental quality (e.g. local } \\
\text { landscape character; therapeutic } \\
\text { landscapes for health and well- } \\
\text { being). } \\
\text { 17. Geotourism \& leisure (e.g. } \\
\text { spectacular mountain views; } \\
\text { outdoor recreation; rock } \\
\text { climbing; fossil collecting). } \\
\text { 18. Cultural, spiritual and historic } \\
\text { meanings (e.g. folklore; sacred } \\
\text { sites; sense of place). } \\
\text { 19. Artistic inspiration (e.g. geology } \\
\text { in sculpture, literature, music, } \\
\text { poetry, painting). } \\
\text { 20. Social development (e.g. local } \\
\text { geological societies; } \\
\text { volunteering; field trips). }\end{array}$ \\
\hline $\begin{array}{l}\text { Provisioning } \\
\text { 9. Food and drink (e.g. freshwater \& } \\
\text { mineral water; salt; geophagy). } \\
\text { 10. Nutrients and minerals for bealthy } \\
\text { growth. } \\
\text { 11. Fuel (e.g. coal, oil, gas, uranium; } \\
\text { geothermal and hydroelectric } \\
\text { energy; tidal, wave and wind power). } \\
\text { 12. Construction materials (e.g. stone, } \\
\text { brick, aggregates, steel, cement, } \\
\text { bitumen, slates, glass). } \\
\text { 13. Industrial minerals (e.g. fertilisers, } \\
\text { pharmaceuticals, metals, alloys). } \\
\text { 14. Ornamental products (e.g. } \\
\text { gemstones, precious and semi- } \\
\text { precious metals). } \\
\text { 15. Fossils. }\end{array}$ & GEODIVERSITY & $\begin{array}{l}\text { 21. Earth history (e.g. evolution of } \\
\text { life; extinction; origin of } \\
\text { landforms; palaeoenvironments). } \\
\text { 22. History of research (e.g. early } \\
\text { identification of unconformities, } \\
\text { fossils, igneous rocks). } \\
\text { 23. Environmental monitoring and } \\
\text { forecasting (e.g. baseline studies } \\
\text { for climate and pollution } \\
\text { research; ice cores; sea-level } \\
\text { change). } \\
\text { 24. Geoforensics. } \\
\text { 25. Education \& employment (e.g. } \\
\text { sites for field trips and } \\
\text { professional training; } \\
\text { employment in geoparks). }\end{array}$ \\
\hline
\end{tabular}

Fluxograma 2: Fluxograma de abiotic ecosystem services. Fonte: GRAY et al., 2013, p. 661.

Essa abordagem destaca os benefícios que podem ser disponibilizados pela geodiversidade, caso deste estudo. Destaca-se, dentre eles, o managing terrestrial and freshwater ecosystem ${ }^{8}$, sobre os benefícios relacionados à gestão hídrica. Na área de estudo, há a APA com a justificativa de ser área de recarga do Aquífero Guarani. Assim, já é de conhecimento das instâncias governamentais que há water regulating services ${ }^{9}$ (benefícios relacionados ao abastecimento e captação de águas) na região. Esse benefício ecossistêmico não é o único identificado na região: também foram identificados benefícios para turismo, refúgio ecológico e pesquisa científica. Távora e Turetta (2016) destacam que é possível uma paisagem ser multifuncional e, para isso, é importante

\footnotetext{
${ }^{8}$ Tradução livre: gerenciamento de ecossistemas terrestres e de captação de água fresca

${ }^{9}$ Tradução livre: benefícios ecossistêmicos de regulação de água
} 
indicar as melhores possibilidades de uso e gestão de uma paisagem para que se potencialize sua função de paisagem de maneira sustentável. Os critérios para a classificação das unidades de paisagem também variaram bastante entre os artigos e, segundo Mateo Rodriguez e Silva (2002), isto é um problema fundamental nos estudos da paisagem. Soto e Pintó (2010) adotaram critérios relacionados aos fatores abióticos para delimitação (elevation, slope, geology), que foram os mais destacados, mas também utilizaram mapeamentos prévios de fatores bióticos (life zones). Bastian (2000) adotou as seguintes fontes para a classificação da paisagem: mapas de solo, geológicos, hidrogeológicos, de biótopos, uso do solo e mapeamentos de estudos da paisagem préexistentes. $\mathrm{O}$ artigo apresenta, ainda, uma tabela com informações detalhadas sobre cada unidade classificada da paisagem, que apresenta características que não foram levadas em conta para a classificação, como clima.

Willemen et al. (2008), para a identificação e regionalização das funções de paisagem, propõe três métodos baseados em: 1) informação espacial e de políticas públicas 2) indicadores espaciais empíricos 3) regras aplicadas após a revisão da literatura. Ao final, os autores destacam que explicitar quais as funções de paisagem de cada área é fundamental para compreender os potenciais da área de estudo. Távora e Turetta (2016) apresentaram os mesmos critérios abióticos que Soto e Pintó (2010), mas também consideraram clima e cobertura vegetal/uso do solo. Nesta pesquisa, os critérios de classificação foram fatores abióticos, sobretudo aqueles relacionados a geologia, geomorfologia (elevação, declividade), pedologia e uso e cobertura do solo. A identificação de suas potencialidades, objetivos e ameaças também foram consideradas, porém em outro nível taxonômico, conforme algoritmo apresentado em Bastian (2000) (figura 11). Assim, os critérios aplicados em Soto e Pintó (2010) e Bastian (2000) foram aplicados na pesquisa. 


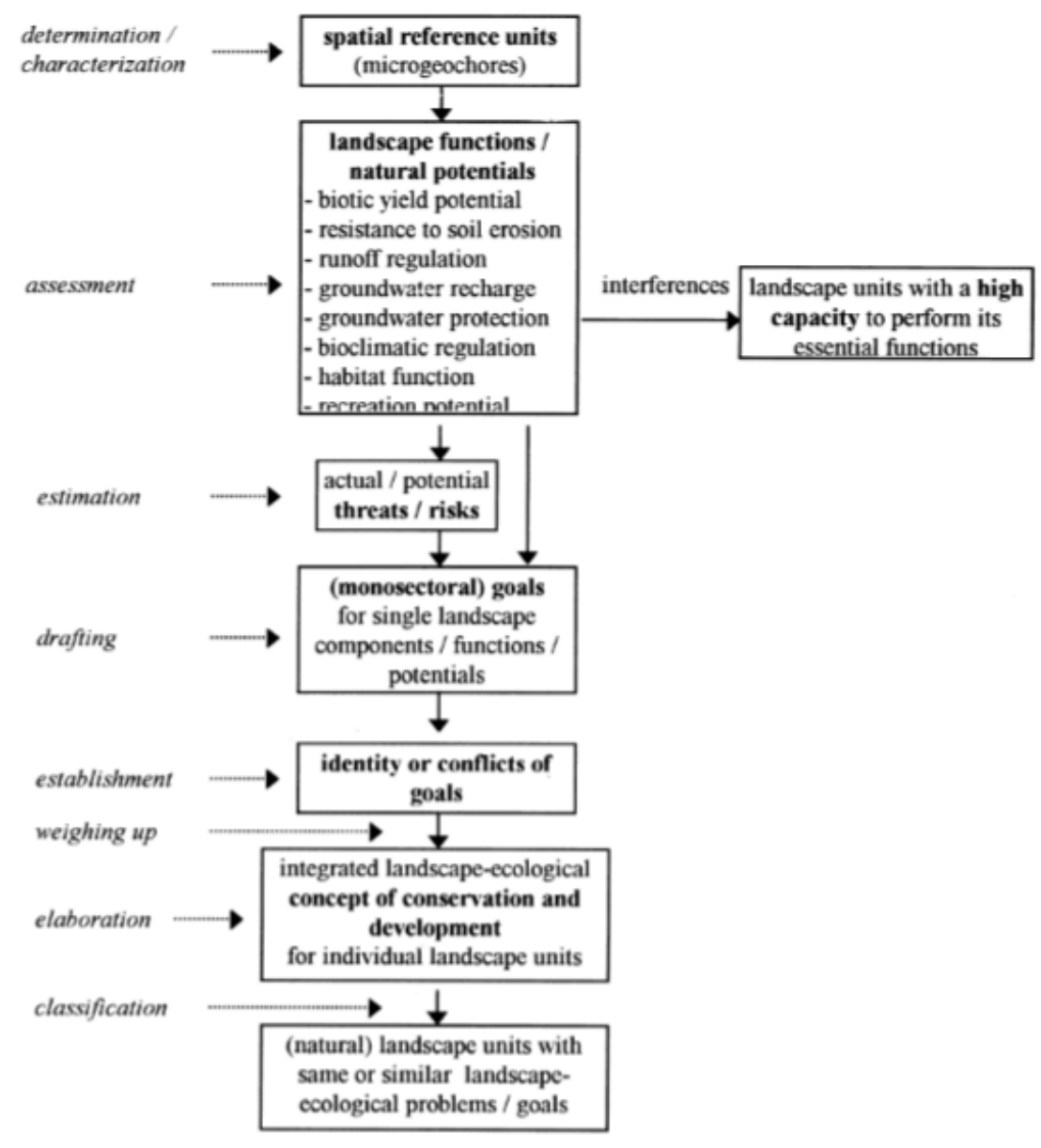

Figura 11: Algoritmo para a elaboração de contribuições ecológicas para a paisagem. Fonte: Bastian, 2000.

Ao propor a delimitação de unidades de paisagem, além de seguir uma metodologia pré-estabelecida e bem embasada, nos deparamos com algumas das premissas que compõem o raciocínio e pensamento geográficos, de acordo com Golledge (2002). Dentre elas, destaco: padrão, hierarquia, regionalização e categorização. A seleção e estabelecimento de critérios para a categorização de uma região compreende um exercício de classificação espacial (regionalização) baseada na identificação de padrões. Por isso, os critérios devem estar expressos e quantificados, quando possível, de maneira objetiva. As formas espaciais podem compor esses critérios: no caso desse trabalho, as variáveis mais destacadas foram as formas de relevo e o padrão de uso e ocupação do solo.

Como ferramenta para a delimitação das unidades de paisagem, todas as pesquisas utilizam softwares de SIG. Soto e Pintó (2010) mesclam estudos de SIG, estatística e modelagem; Távora e Turetta (2016), assim como Willemen et al. (2008), integram os 
trabalhos em SIG à estatística. Nessa etapa, destacou-se a questão do overlay e seus limites. Na pesquisa, mapas de geomorfologia, pedologia e geologia foram sobrepostos para a definição do primeiro nível de unidade de paisagem (assim como em Távora e Turetta, (2016). Outro fator importante para as pesquisas em estudos da paisagem é a taxonomia adotada, intrinsecamente ligada à classificação das unidades de paisagem. Soto e Pintó (2010) diferencia landscape type de landscape unit. Landscape unit é definido no trabalho como: "A landscape unit represents a homogeneous territory with a unique physiognomy, structure, and physiography"10 (ZONNEVELD, 1995 apud SOTO E PINTÓ, 2010, p.720).

No mesmo artigo, landscape type seriam áreas mais heterogêneas em escala de menor detalhe. Bastian (2000) apresenta a hierarquia principalmente entre diferentes unidades do relevo, abordando meso-relevo. Távora e Turetta (2016) estabeleceram uma hierarquização da paisagem que considerava: nível 1: domínios geomorfológicos (geomorfologia e geologia); nível 2: padrões de forma de relevo (formas de relevo e solos); nível 3: unidades de paisagem (solos e uso da terra/cobertura vegetal). Conforme já indicado, a pesquisa levou em conta fatores abióticos e fatores associados ao uso do solo em escala de maior detalhe. Assim, a hierarquização de Távora e Turetta (2016) se aproxima da metodologia adotada nesta pesquisa.

Beunen e Opdam (2011) fazem considerações sobre o papel do conhecimento científico no planejamento e tomada de decisão sobre as paisagens, seus usos e demandas futuras. Os autores concluem que é necessário maior reflexão sobre a aplicabilidade das pesquisas científicas no planejamento e propõem questões sobre essa lacuna entre pesquisa e planejamento:

- Quais critérios os tomadores de decisão usam para avaliar a pesquisa científica?

- Quais são as características chave do saber científico que influenciam a tomada de decisões e gestão da paisagem?

- Como podemos identificar o que já foi incorporado do saber científico à gestão da paisagem?

Manter essas questões e esse tipo de reflexão ao longo do trabalho de pesquisa auxilia na confecção de um produto final que seja factível para aplicação, mesmo que não

\footnotetext{
${ }^{10}$ Tradução livre: Uma unidade de paisagem representa um território homogêneo com fisionomia, estrutura e fisiografia únicas
} 
seja o objetivo final da pesquisa, e se constitui numa ferramenta de auxílio para a tomada de decisão e gestão da paisagem.

\section{$\underline{3.3 \text { Geoturismo }}$}

O Sistema Nacional de Unidades de Conservação (SNUC) cita a beleza cênica como um de seus objetivos de conservação:

Art. 4o O SNUC tem os seguintes objetivos:

I - contribuir para a manutenção da diversidade biológica e dos recursos genéticos no território nacional e nas águas jurisdicionais;

$[\ldots]$

VI - proteger paisagens naturais e pouco alteradas de notável beleza cênica;

VII - proteger as características relevantes de natureza geológica, geomorfológica, espeleológica, arqueológica, paleontológica e cultural;

VIII - proteger e recuperar recursos hídricos e edáficos;

IX - recuperar ou restaurar ecossistemas degradados;

$\mathrm{X}$ - proporcionar meios e incentivos para atividades de pesquisa científica, estudos e monitoramento ambiental;

XI - valorizar econômica e socialmente a diversidade biológica;

XII - favorecer condições e promover a educação e interpretação ambiental, a recreação em contato com a natureza e o turismo ecológico (BRASIL, 2000, p.1)

A identificação da beleza cênica de uma paisagem não é suficiente para promover o estímulo ao turismo no local. De acordo com o Ministério do Turismo (MTur), o inventário da oferta turística é uma das primeiras etapas para avaliação de um local para a atividade turística. O Inventário da Oferta Turística, lançado pelo MTur em 2011, dá diretrizes sobre esse ponto. De acordo com esse documento (LIMA, 2011, p. 20):

Inventariar significa registrar, relacionar, contar e conhecer aquilo de que se dispõe e gerar informação, para pensar de que maneira se pode atingir determinada meta. No caso do turismo, o inventário consiste em levantar, identificar, registrar e divulgar os atrativos, benefícios e equipamentos turísticos, as estruturas de apoio ao turismo, as instâncias de gestão e outros itens e condições gerais que viabilizam a atividade turística, como base de informações para que se planeje e gerencie adequadamente o processo de desenvolvimento. O intuito é dar conhecimento do que um município tem que seja passível de utilização para fins turísticos para 
embasar as ações de planejamento, gestão, promoção e incentivo à comercialização do turismo a partir da adoção de uma metodologia-padrão para inventariar a oferta turística no país, de modo a disponibilizar aos planejadores, gestores e visitantes informações confiáveis e atuais.

Assim, o planejamento é uma etapa prevista para o inventário turístico no Brasil, que reconhece o ambiente como um sistema físico e biológico a ser considerado na execução de seus objetivos e o ordenamento territorial como um processo do planejamento voltado para a avaliação e programação do uso do solo e manejo dos recursos naturais.

O levantamento bibliográfico sobre turismo apresentou uma forma ascendente de turismo que melhor se adapta ao caso de estudo do que o Ecoturismo, o Geoturismo, definido como "uma forma de turismo em área natural que foca especialmente na paisagem e geologia. Isto promove o turismo a geossítios e a conservação da geodiversidade e o entendimento de ciências da Terra para apreciação e aprendizagem." (NEWSOME E DOWLING, 2010).

O Geoturismo, conforme citado anteriormente, apresentou-se como uma forma mais eficaz à apreciação turística da área de estudo, pois, além da visitação ao local, ele pressupõe a existência de programas de conservação do ponto turístico e programas de conscientização dos fenômenos geológicos e geográficos que ocorrem na área (NEWSOME E DOWLING, 2010). Além disso, Nascimento et al. (2008) apresentam diversos exemplos bem sucedidos ao alinhar geoturismo e conservação do patrimônio geológico, como o Geopark Araripe, no Ceará. Tal perspectiva adotada é de grande importância dado a preocupação recente do Governo do Estado de São Paulo em preservar as formas geológicas e geomorfológicas excepcionais do estado, constituintes da Geodiversidade, termo com várias definições e que, neste trabalho, será abordada conforme definição do Serviço Geológico do Brasil (CPRM, 2016): “o estudo da natureza abiótica (meio físico) constituída por uma variedade de ambientes, composição, fenômenos e processos geológicos que dão origem às paisagens, rochas, minerais, águas, fósseis, solos, clima e outros depósitos superficiais que propiciam o desenvolvimento da vida na Terra, tendo como valores intrínsecos a cultura, o estético, o econômico, o científico, o educativo e o turístico."

Dentro deste contexto, a Secretaria de Estado do Meio Ambiente estabeleceu o COMGEO (Conselho Estadual de Monumentos Geológicos do Estado de São Paulo, 
Resolução SMA no 076, de 04 de novembro de 2009), subordinado ao Instituto Geológico, na qual Monumentos Geológicos são definidos como "elementos da Geodiversidade que são particularmente importantes devido a seu alto valor científico, sua raridade e sua excepcionalidade" (INSTITUTO GEOLÓGICO, 2010). Segundo este órgão, "um Monumento Geológico (ou Geossítio) representa a ocorrência de um ou mais elementos da Geodiversidade com especial importância para a sociedade devido ao seu alto valor científico, pedagógico, cultural, turístico, etc".

O ComGeo cataloga os monumentos geológicos do estado de São Paulo com intuito de localizá-los e divulgá-los por meio de inventário e levantamento de diversos dados, dando suporte a ações de planejamento territorial sobre estas áreas (INSTITUTO GEOLÓGICO, 2010). Após a leitura dos resultados, é possível atribuir ao morrotestemunho Torre de Pedra potencial para ser um monumento geológico paulista.

Ruban (2015) fez um levantamento bibliográfico sobre os estudos recentes relacionados ao geoturismo, analisando como eles estão distribuídos pelo mundo e sua frequência de acordo com o país. O autor levanta diversas hipóteses para justificar essa distribuição. As pesquisas sobre o tema estão concentradas a Europa (Itália e Polônia), Ásia (China e Irã) e América do Sul (Brasil). Existe um crescimento constante de estudos nessa área desde os anos 2000. É interessante notar que, no Brasil, só há um geoparque, enquanto países com mais geoparques não tem tantos especialistas em geoturismo.

Apesar dessa diversidade de estudos sobre geoturismo e geodiversidade (relacionado aos pontos contemplados no geoturismo), são raras as pesquisas que relacionam essa temática à teoria da paisagem. Gray et al. (2013) estabelece essa relação, analisando como a geodiversidade é subestimada na United Kingdom National Ecosystem Assessment (UKNEA) e elencando pontos que justificam a importância da geodiversidade e outros estudos de geociências para esse tipo de avaliação. Os autores tratam especificamente do Sistema de Avaliação de Ecossistemas do Reino Unido e da menor importância dada aos geossítios e elementos da geodiversidade nesse documento, mas também apresentam pontos comuns e genéricos que justificam a importância da geodiversidade, pontos chamados de abiotic ecosystem services (uma vertente de ES), ou seja, benefícios que esses pontos podem trazer à sociedade. Dentre eles, já foi destacado anteriormente o benefício que está presente na área de estudo deste trabalho, o managing terrestrial and fresh water ecosystems.

A definição de geoturismo e geodiversidade é debatida em Newsome et al. (2012). No artigo, os autores elucidam características e desafios do geoturismo e sua influência 
na gestão territorial, por meio do estudo de caso de duas regiões geoturísticas já consagradas (uma em Taiwan e outra na Austrália). Esses autores são referências em pesquisas sobre Geoturismo e, nesses estudos de caso, apresentam formas de classificar os pontos geoturísticos dependendo de seu foco. Partindo dessa abordagem, a área de estudo desta pesquisa entraria nas categorias landscapes/viewscapes e landforms. Os autores apresentam características que poderiam beneficiar a gestão do geoturismo e sua manutenção em uma certa região, como: desenvolvimento de programas de educação ambiental, interação com a comunidade local e geração de renda. O principal objetivo do geoturismo, de acordo com os autores, é "to foster tourism development opportunities whilst at the same time ensuring the conservation and/or protection of geoheritage attributes" $^{11}$ (NEWSOME et al., 2012, p.21). Contudo, os autores ponderam que o geoturismo é uma atividade que resulta em uma vasta gama de impactos e, por isso, medidas restritivas de acesso podem ser necessárias, baseadas em estudos e pesquisas sobre o tema.

Existem diversos estudos de caso sobre geoturismo e geodiversidade, porém poucos propõem uma metodologia de averiguação quantitativa das paisagens. Pralong (2005) é um exemplo desse caso: o artigo apresenta um método de avaliação dos valores de turismo e de exploração de áreas com excepcionalidade geomorfológica levando em consideração critérios pré-estabelecidos: cênico, científico, cultural e econômico. No critério cênico, é avaliado o aspecto espetacular da área; no científico, avalia-se o quão extraordinário e o raro é o ambiente estudado. No critério cultural, verifica-se se há alguma atividade cultural ou artística relacionada a área e, por fim, o critério econômico é baseado nas características economicamente úteis da área. Para cada critério, foram estabelecidas notas (ou graus) de 0 a 1 . A média desses valores corresponde ao valor final de cada critério na avaliação final.

\section{PROCEDIMENTOS METODOLÓGICOS E OPERACIONAIS}

Para atingir os objetivos propostos, foi realizada uma análise integrada baseada na delimitação das unidades de paisagem, avaliando as potencialidades e restrições de cada unidade identificada, além dos benefícios ecossistêmicos que as caracterizam. Essa

\footnotetext{
${ }^{11}$ Tradução livre: Desenvolver oportunidade de turismo que também garantam a conservação ou proteção de atributos de geodiversidade
} 
análise foi proposta a partir de três principais referências apresentadas no capítulo anterior:

a) Delpoux (1974) contribuiu para a determinação da separação dos tipos de mapeamento: aspectos de estrutura e suporte (geologia, geomorfologia, pedologia) e aspectos de cobertura (uso do solo e cobertura vegetal);

b) Mateo-Rodriguez et. al (2007), foram consideradas as dinâmicas dentro das unidades de paisagens;

c) Por fim, a leitura de Távora e Turetta (2016), contribuiu para que se identificasse os benefícios ecossistêmicos e critérios de delimitação das unidades de paisagem.

A delimitação das unidades de paisagem se baseou em levantamentos bibliográficos, mapeamentos síntese das unidades de paisagem, realização de trabalho de campo para coleta de dados primários e tratamento de dados após campo. Para a realização desta pesquisa (fluxograma 3), as seguintes etapas foram estabelecidas: avaliação da situação atual da área de estudo (4.1), trabalhos de campos (4.2) e o mapeamento síntese, que resultou no mapa de unidades de paisagem (4.3).

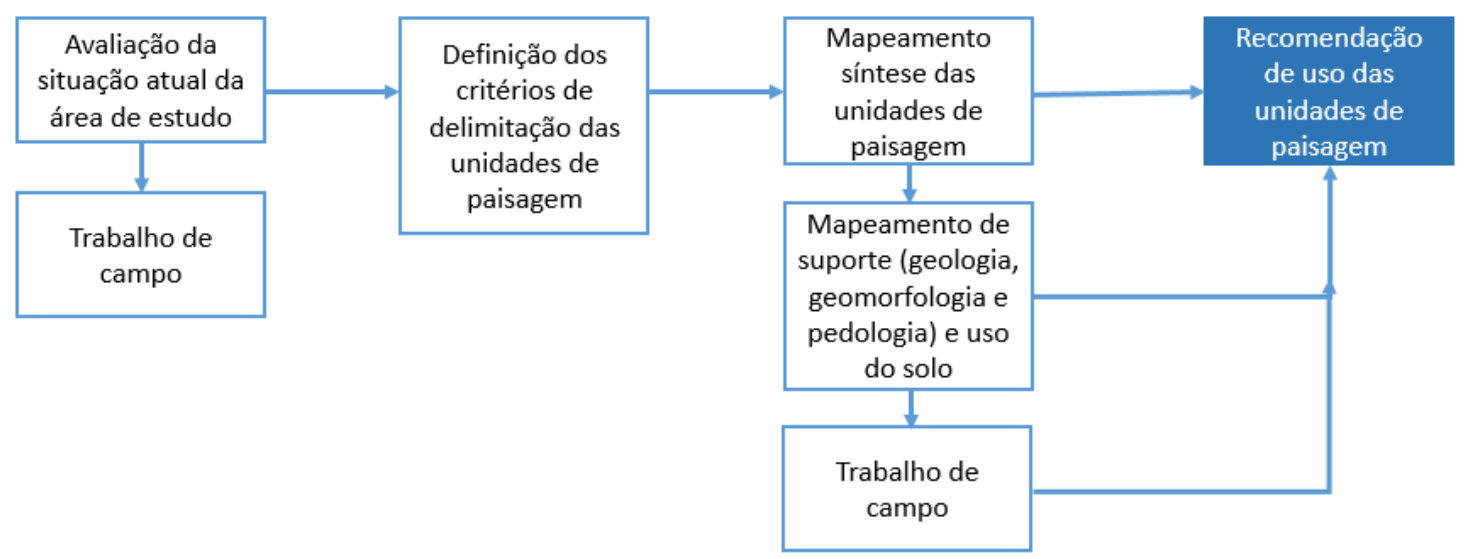

Fluxograma 3: Fluxograma de etapas metodológicas. Elaborado pela autora.

\subsection{Avaliação da situação atual da área de estudo}

Antes da delimitação das unidades de paisagens e seus respectivos critérios, foi realizada uma avaliação qualitativa do uso e ocupação do solo da região. Nesta etapa, foram avaliados:

a) Planos de manejo da APA já existente na região; 
b) Situação de conservação do morro-testemunho e situações de degradação ambiental na área de estudo, observado no trabalho de campo.

\subsection{Trabalho de campo}

Os trabalhos de campos foram realizados em dois momentos:

1) Realizado previamente para reconhecimento da área de estudo e levantamento de dados primários, principalmente sobre hidrografia e estado de conservação ambiental da área de estudo;

2) Averiguação dos dados apresentados após o mapeamento de suporte.

\subsection{Mapeamento síntese}

\section{3a Critérios de delimitação das Unidades de Paisagem}

Delpoux (1974) assumia que a dinâmica da paisagem pode ser estudada a partir da análise da combinação entre os elementos de sua estrutura (geologia, pedologia, geomorfologia) e de sua cobertura (uso do solo, áreas de proteção ambiental, entre outros). Partindo dessa premissa, o modelo de delimitação de unidades de paisagens desse trabalho foi executado pela caracterização de fatores abióticos e, em seguida, fatores bióticos e de uso do solo, assim como em Távora e Turetta (2016) e Mateo-Rodriguez et al. (2007).

A hierarquização da paisagem considerou três níveis (fluxograma 4):

Nível 1) Domínios geomorfológicos (geomorfologia e geologia)

Nível 2) Padrões de forma de relevo (formas de relevo e solos)

Nível 3) Unidades de paisagem (solos e uso da terra/cobertura vegetal) 


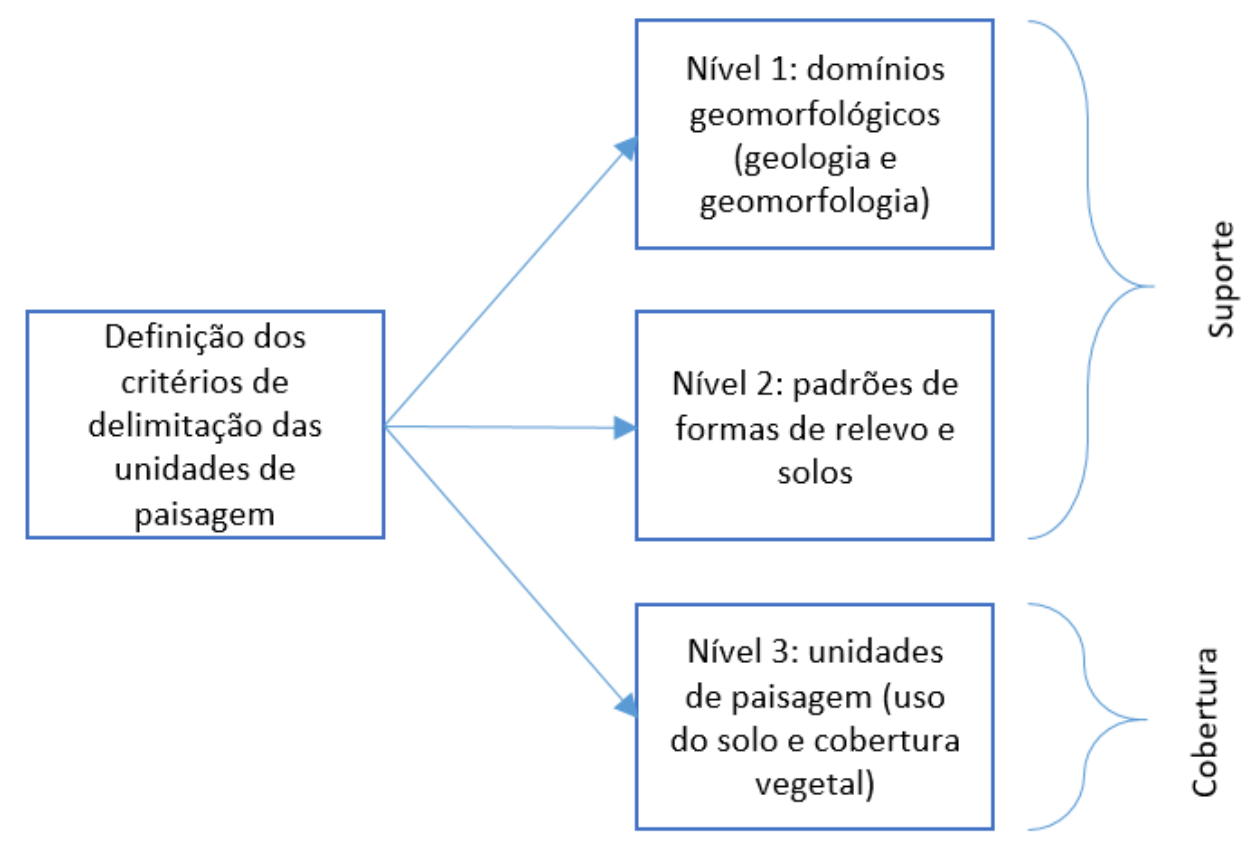

Fluxograma 4: Fluxograma com os critérios de delimitação das unidades de paisagem. Elaborado pela autora.

As variáveis do trabalho estão relacionadas aos critérios selecionados para a delimitação das unidades de paisagem:

- Variável teórica: unidades de paisagem definida pela sua função e dinâmica

- Variáveis operacionais: uso do solo e cobertura vegetal, forma de relevo, pedologia, litologia.

A delimitação das Unidades de Paisagem levou em conta fatores abióticos e fatores associados ao uso do solo e cobertura vegetal. Assim, a hierarquização proposta leva em consideração esses fatores no nível de maior detalhamento. Mateo-Rodriguez et al. (2007) apresentam um quadro comparativo de classificação das unidades de paisagem a partir de diferentes escolas de estudo da paisagem. A classificação desta pesquisa se aproxima do sistema de classificação geomorfológica.

A partir dessa delimitação foi possível a identificação das potencialidades e restrições de uso e ocupação da terra presentes na área de estudo e a consequente proposta de ordenamento territorial com ênfase voltada à preservação do morro-testemunho de Torre de Pedra e seu entorno. 


\section{$\underline{4.3 b}$ Mapeamento síntese}

Como produto final, a análise entre compartimentação geomorfológica, geologia, pedologia e o uso do solo da área de estudo culminou na confecção do mapa de Unidades de Paisagem, com a descrição de cada unidade de paisagem, além das recomendações de uso e restrições de ocupação. A escala adotada para os mapas foi 1:60.000, que permite abranger todo o município de Torre de Pedra.

Os mapas foram realizados pelo software livre de geoprocessamento Q-GIS, versão 18. A partir das bases cartográficas indicadas no quadro 3, foram confeccionados os mapas indicados no capítulo a seguir.

Quadro 3: Bases cartográficas utilizadas na pesquisa.

\begin{tabular}{|ll|}
\hline Base cartográfica & Disponível em: \\
\hline Base municipal & DataGeo, IGC \\
do Estado de São Paulo & \\
\hline Mapa pedológico & SÃO PAULO, 2011; trabalhos de campo; \\
& ROSSI, 2017 \\
\hline Mapa geológico & CPRM, 2018 \\
\hline Mapa geomorfológico & Ross E Moroz, 1997 \\
\hline Uso do solo & GoogleEarth; trabalhos de campo \\
\hline Imagens de satélite & GoogleEarth, 2018 \\
\hline
\end{tabular}




\section{RESULTADOS}

\section{1 Avaliação da situação atual da área de estudo}

Uma avaliação qualitativa do uso e ocupação do solo do município de Torre de Pedra foi realizada em duas etapas:

a) Avaliação do plano de manejo já existentes na APA;

b) Situação de conservação do morro-testemunho (através da avaliação da literatura prévia sobre o tema e trabalhos de campo).

\section{$\underline{\text { 5.1.a Avaliação do plano de manejo da APA Corumbataí, Botucatu e Tejupá }}$}

A APA Corumbataí, Botucatu e Tejupá foi estabelecida pelo Decreto Estadual No 20,960, de 8 de junho de 1983, e é composta por três perímetros. Cerca de metade do município de Torre de Pedra $(51,62 \%)$ está inserido na APA Corumbataí, Botucatu e Tejupá - Perímetro Botucatu.

As justificativas para o estabelecimento da APA nesta região foram: a preservação da vegetação e fauna remanescentes da Mata Atlântica e transição para o Cerrado que existe na região (SÃO PAULO, 1983) e garantir a recarga de águas do Aquífero Guarani (mapa 1).

Em 2011, foi elaborado o Plano de Manejo da APA Corumbataí, Botucatu e Tejupá, em cinco volumes. Segundo esse documento,

[...] Após a Lei $\mathrm{n}^{\circ}$ 9.985, que instituiu o Sistema Nacional de Unidades de Conservação da Natureza - SNUC, regulamentada pelo Decreto $\mathrm{n}^{\mathrm{o}}$. 4.340 de agosto de 2002, o Plano de Manejo passou a ser o documento orientador de todas as atividades a serem desenvolvidas nas unidades de conservação, sendo obrigatória a elaboração do Plano de Manejo das unidades de conservação no prazo de cinco anos a partir da data de sua criação. A lei também esclarece que é proibida qualquer intervenção, alteração, desenvolvimento de atividades ou modalidades de utilização nas unidades de conservação em desacordo com seus objetivos, o seu Plano de Manejo e seus regulamentos.

Nas APAs podem coexistir propriedades públicas e privadas, atividades socioeconômicas urbanas e rurais e áreas de interesse para a conservação do patrimônio natural e históricocultural. Devem, portanto, ser entendidas como UC com características mistas, onde se busca a conservação do patrimônio natural associada às condições de ocupação humana que se estabelecem nesse território e aos princípios constitucionais que garantem o direito à propriedade privada [...] (SÃO PAULO, 2011, p. 1) 

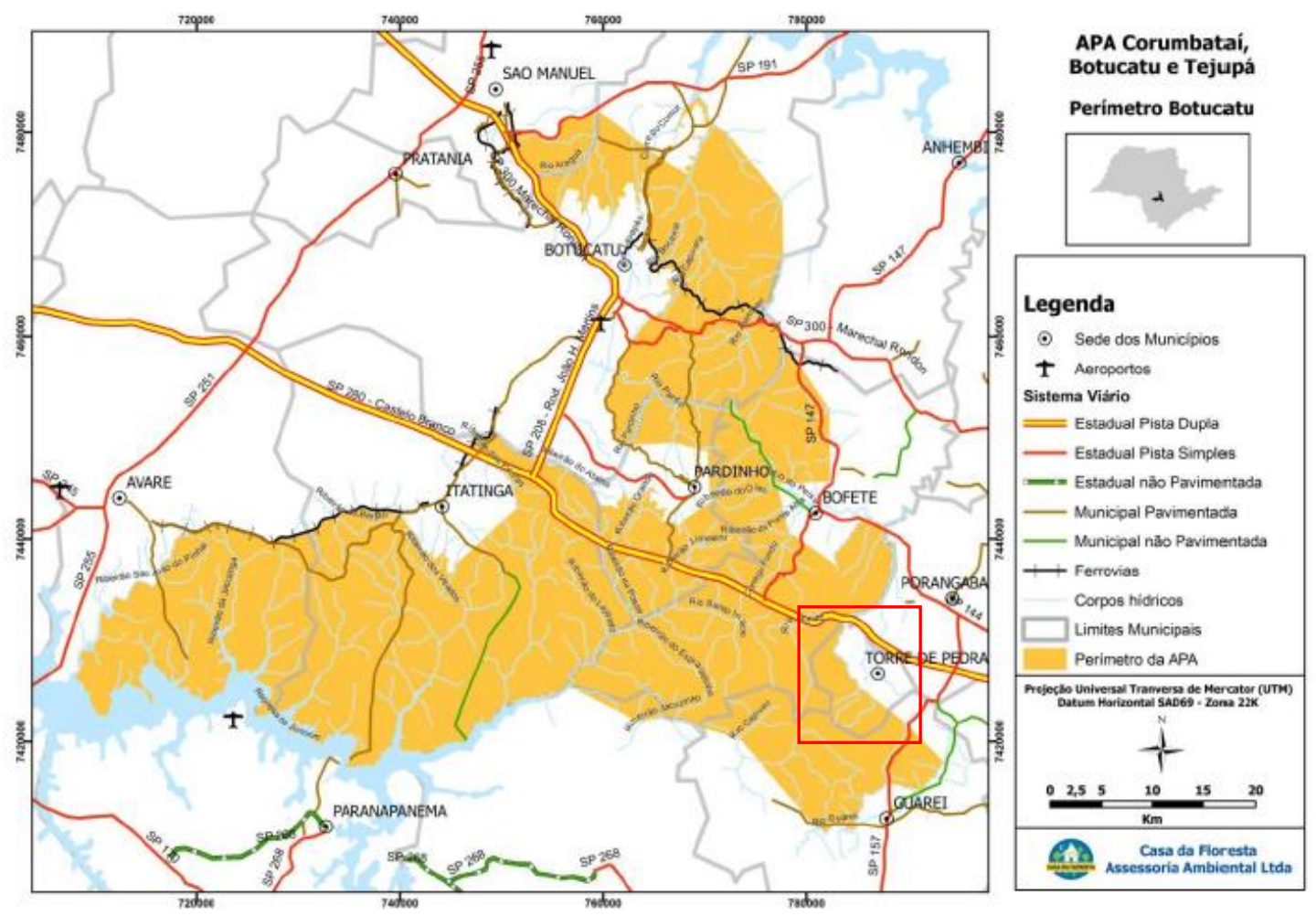

Mapa 1: Mapa da APA Corumbataí, Botucatu e Tejupá - Perímetro Botucatu. Fonte: SÃO PAULO, 2011.

O Plano de Manejo da APA Corumbataí, Botucatu e Tejupá é composto por cinco volumes. Para essa pesquisa, foram avaliados mais profundamente os volumes 1 (Diagnóstico Socioambiental) e 2 (Planejamento Participativo). O volume 1, Diagnóstico Socioambiental, contém os seguintes itens: abordagem metodológica, diagnóstico ambiental (meio físico, meio biótico, meio social) referências bibliográficas e anexos. As metodologias utilizadas para esse diagnóstico adotaram o levantamento de dados secundários sobre os aspectos mencionados, em diferentes fontes. O volume 2, Planejamento Participativo, contempla uma avaliação estratégica da APA, assim como um Zoneamento e Planejamento, com recomendações de manejo para a área.

Ao tratar dos aspectos físicos, o documento faz um panorama dos principais aspectos geológicos, geomorfológicos, climáticos, pedológicos, estratigráficos e da vegetação da área da APA. Sobre a vegetação do município da Torre de Pedra, o Plano de Manejo cita aspectos de dois tipos de vegetação, Mata Atlântica e Cerrado, que foram confirmados no trabalho de campo e em outros trabalhos sobre o município (FARIA, 2014) (figuras 13 e 14). 


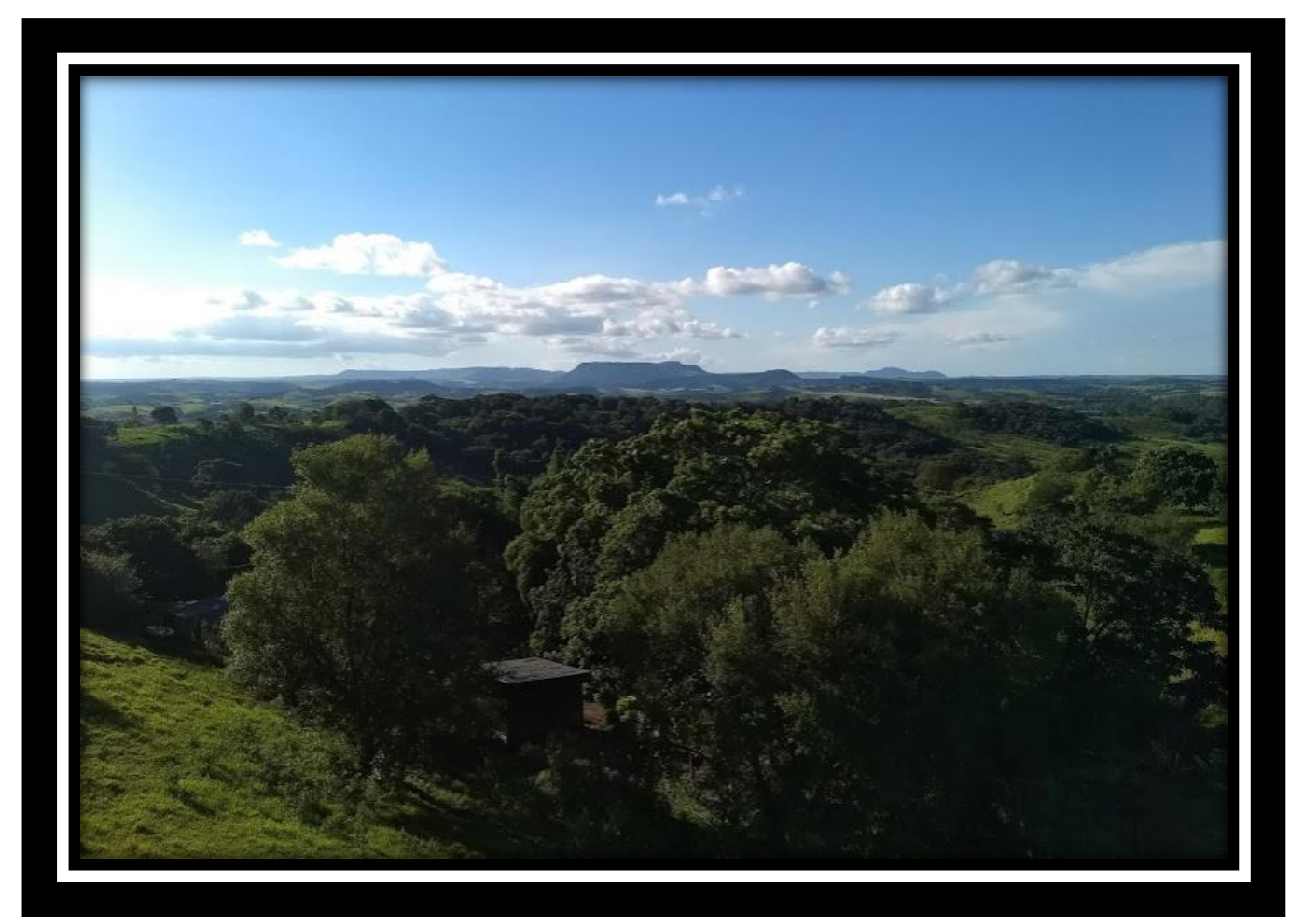

Figura 12: Fotografia de vegetação com características de Mata Atlântica no município de Torre de Pedra (SP). Ao fundo, observa-se um trecho da cuesta de Botucatu. Foto: Jéssica Vieira de Faria, 2018.

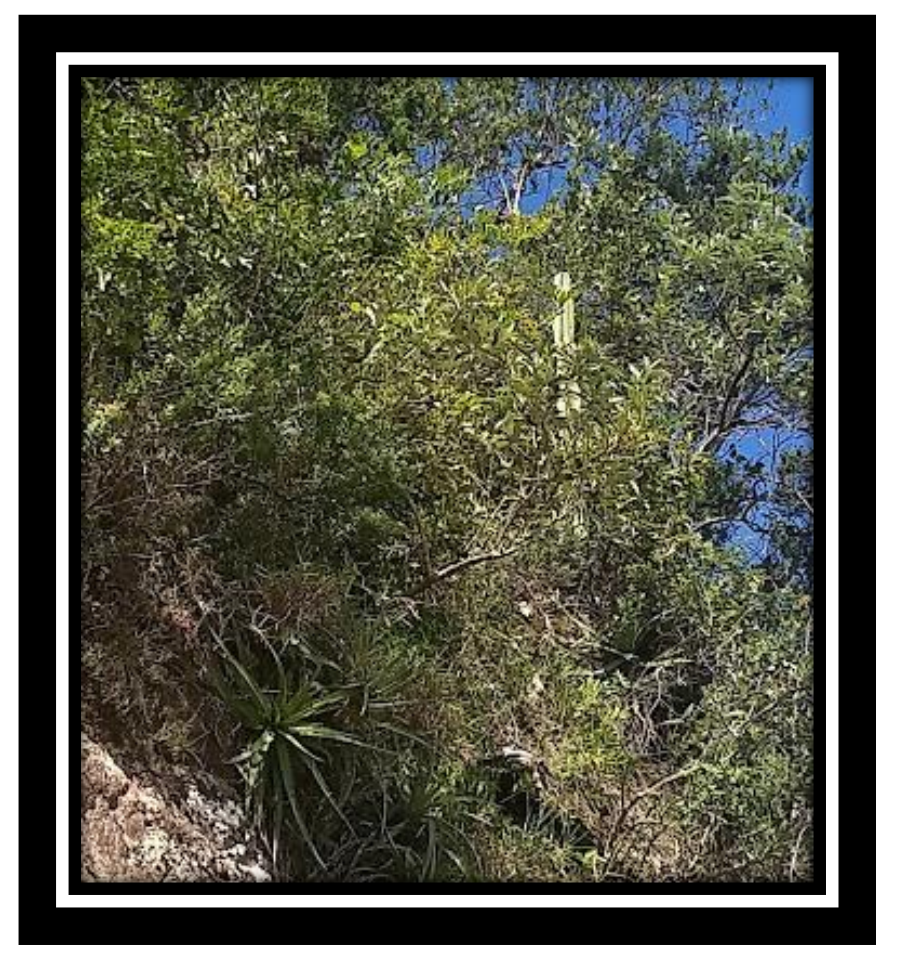

Figura 13: Fotografia de vegetação com características de Cerrado no sopé do morrotestemunho Torre de Pedra, no município de Torre de Pedra (SP). É possível observar uma diversidade de espécies nessa fotografia, como bromélias, cactos e arbustos de porte pequeno e médio. Foto: Jéssica Vieira de Faria, 2018. 
Ainda no item sobre aspectos físicos, chamam a atenção os estudos sobre hidrografia, que focam sobretudo no aquífero Guarani (Mapa 2). É possível verificar, no mapa, que o município de Torre de Pedra, assim como a maior parte da área da APA, tem áreas de afloramento do Aquífero Guarani, como pode ser verificado no trabalho de campo, com a identificação de bicas d'água utilizadas pela população em geral (Figura $14)$.

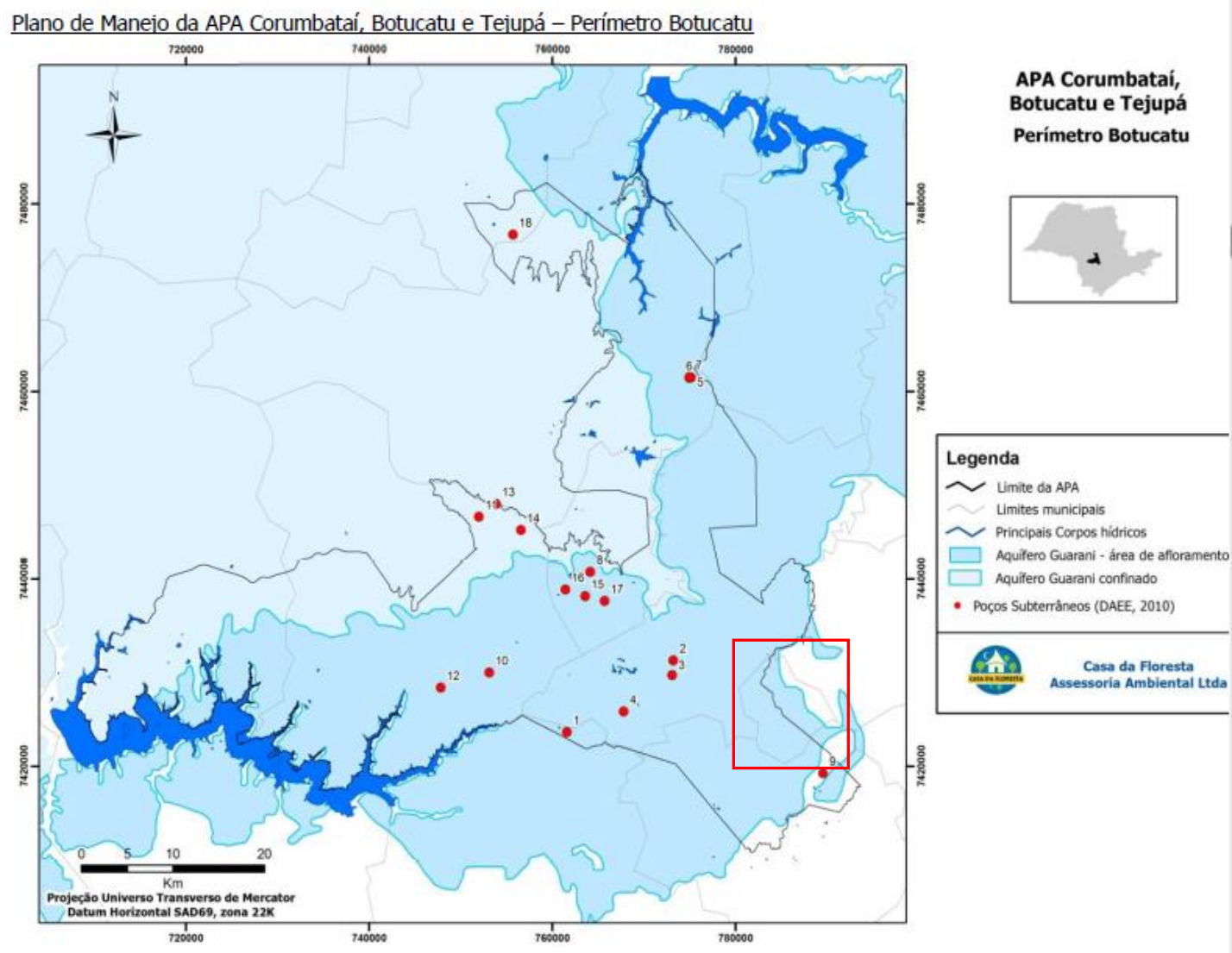

Mapa 2: Mapa da exploração do Aquífero Guarani na APA Corumbataí, Botucatu e Tejupá - Perímetro Botucatu. Destaque em vermelho para o município de Torre de Pedra. Fonte: SÃO PAULO, 2011. 


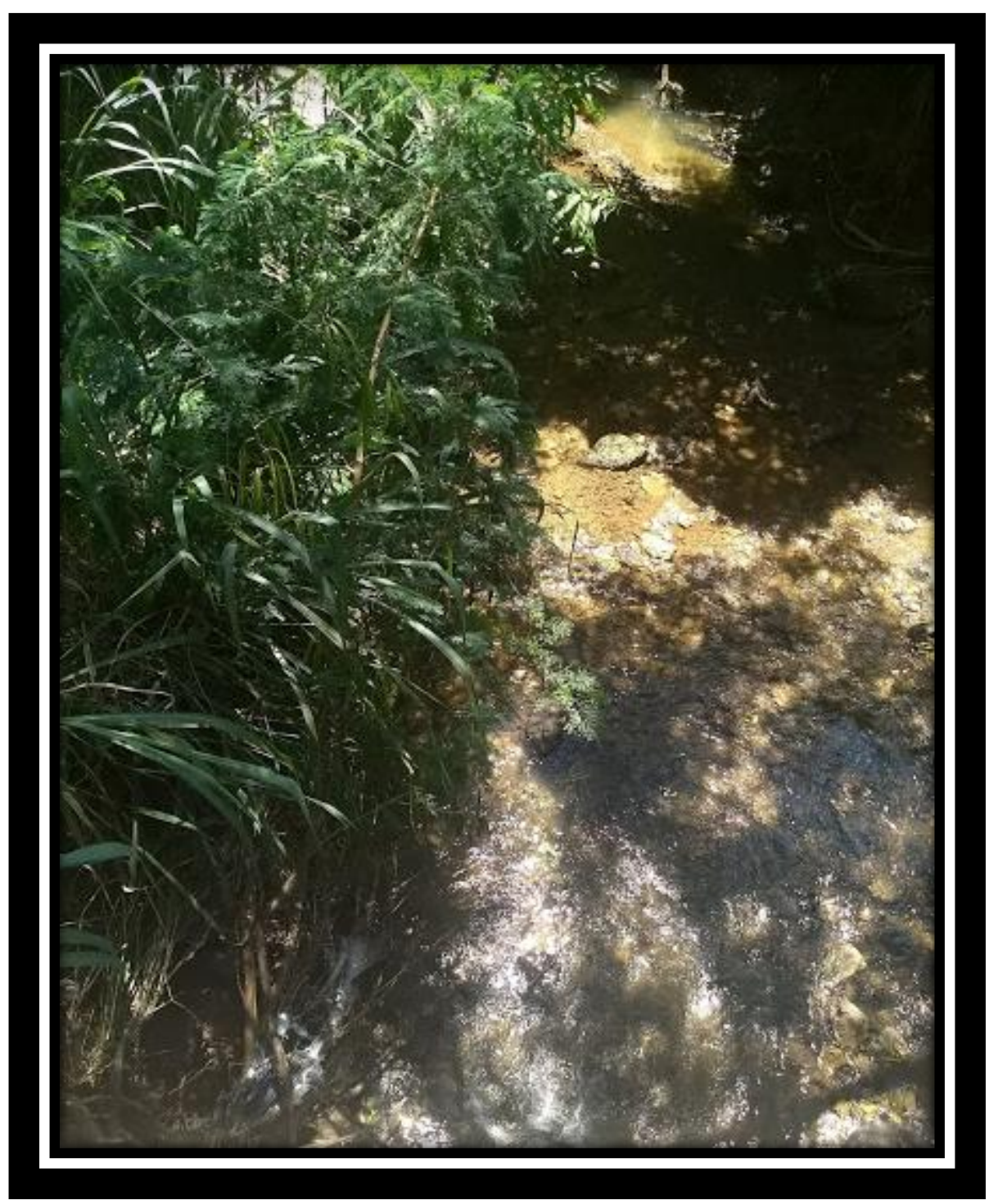

Figura 14: Fotografia de córrego próximo ao morro-testemunho Torre de Pedra, no município de Torre de Pedra (SP). Foto: Jéssica Vieira de Faria, 2018.

Ainda sobre o meio físico, a figura a seguir (Figura 15), presente no volume 2 do plano de manejo da APA, apresenta as cuestas e morro-testemunhos dentro da APA. Conforme destaque para o município de Torre de Pedra, as manchas em roxo representam o Morro Agudo e a Torre de Pedra, áreas de grande interesse geomorfológico para a região. 


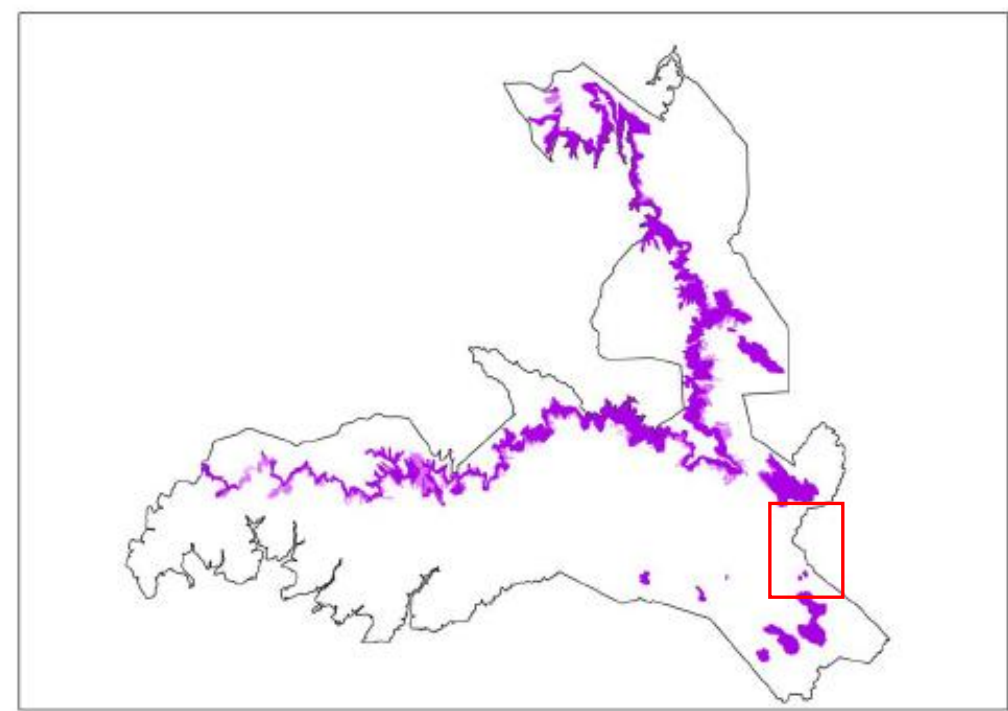

Figura 15: Delimitação das cuestas e morro-testemunhos na APA Corumbataí, Botucatu e Tejupá - Perímetro Botucatu. Destaque em vermelho para o município de Torre de Pedra. Fonte: São Paulo, 2011.

No tocante aos aspectos socioeconômicos, contemplados no item Meio Social do volume 1 do plano de manejo, o documento apresenta dados sobre uso e ocupação do solo da área da APA, além de informações sobre a hierarquia urbana local (fluxograma 5).

De acordo com esse item, o município de Torre de Pedra apresenta perfil de serviços de administração pública, ou seja, a economia local gira em torno da administração pública do município (mapa 3).

No tocante a rede urbana, o município de Torre de Pedra, apesar de estar historicamente conectado ao município de Porangaba, tem como centro de zona o município de Tatuí, distante cerca de 50 quilômetros. De acordo com a hierarquia urbana do IBGE, os centros de zona referem-se a cidades de menor porte cuja atuação está restrita à sua área imediata, enquanto os centros locais são cidades cuja centralidade e atuação não extrapolar os limites municipais (IBGE, 2008). Considerar as relações urbanas é importante ao propor uma atividade que exija uma diversidade de serviços, como o turismo. 


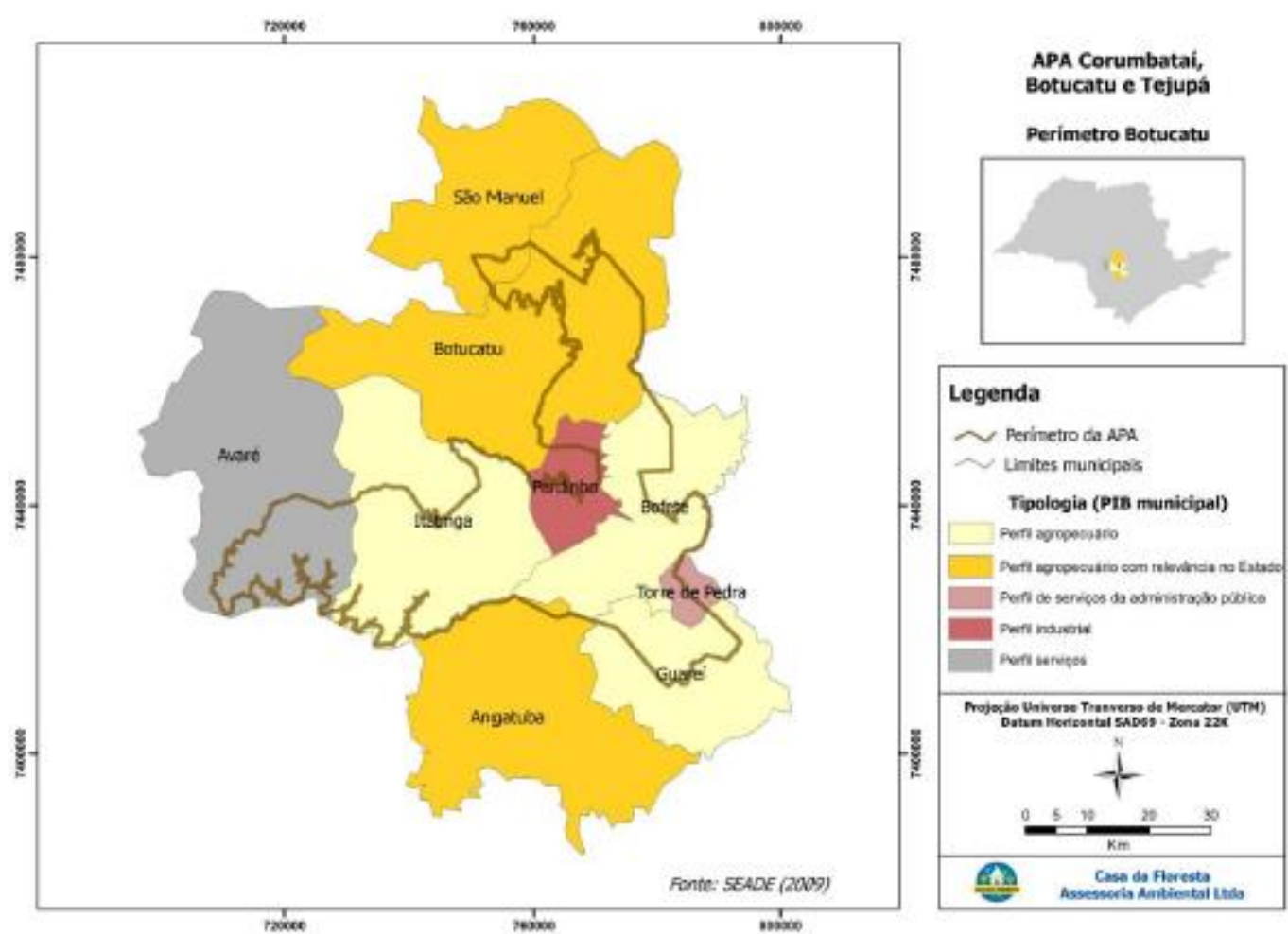

Mapa 3: Tipologia dos municípios da APA Corumbataí, Botucatu e Tejupá Perímetro Botucatu, baseadas no PIB municipal (2007). Fonte: São Paulo, 2011.

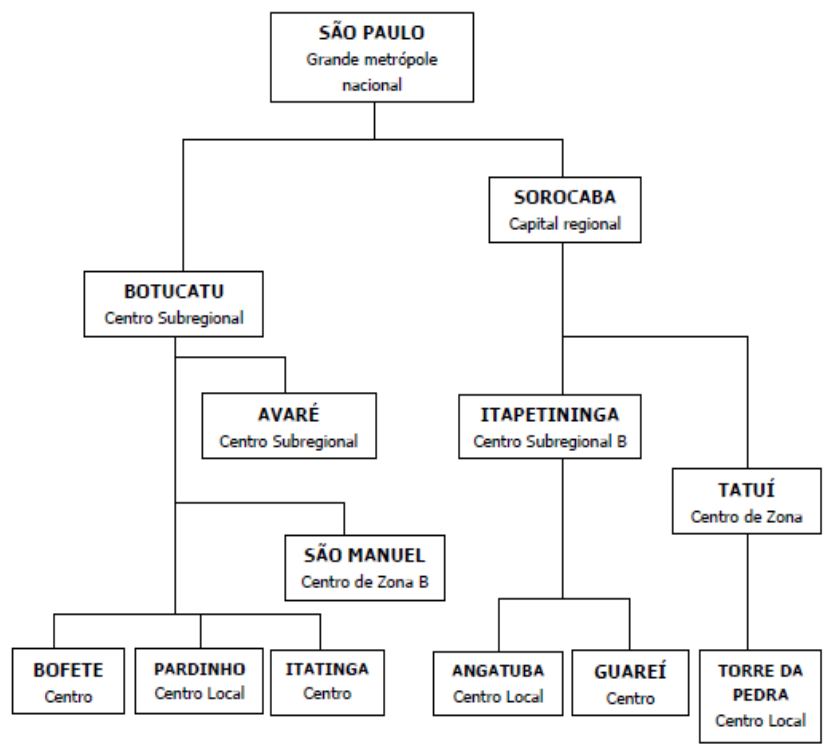

Figura 3.4/14: Rede urbana dos municípios da APA Corumbataí, Botucatu e Tejupá, perímetro Botucatu, segundo IBGE (2007). Fonte: IBGE (2007).

Fluxograma 5: Rede urbana dos municípios da APA Corumbataí, Botucatu e Tejupá - Perímetro Botucatu, IBGE (2007). Fonte: São Paulo, 2011. 
Em relação ao uso do solo, as pastagens ocupam a maior parte do solo do município de Torre de Pedra (gráfico 1). Esse dado se manteve estável durante esta pesquisa, conforme o próximo item dos resultados da pesquisa (mapeamento do uso do solo do município). Em 2018, após o mapeamento, constatou-se que essa situação de uso do solo não se alterou: as pastagens continuam representando a maior porcentagem de uso do solo no município, com pequeno aumento das áreas de reflorestamento, sobretudo silviculturas.

Gráfico 1: Percentual das atividades agrosilvopastoris do município de Torre de Pedra (2006). Fonte: SÃO PAULO, 2011.

\section{Torre de Pedra}

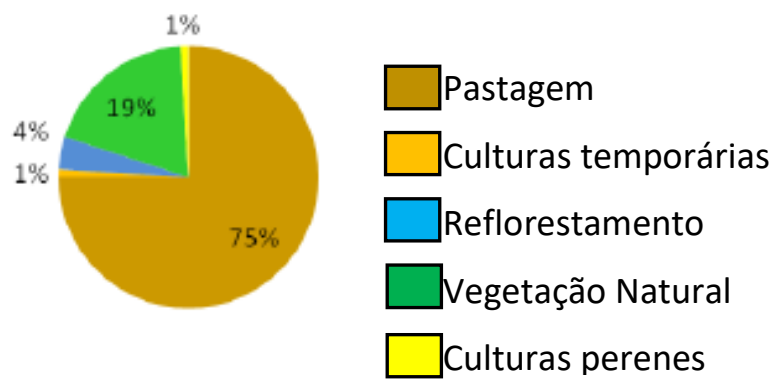

Ao tratar do Potencial Turístico dos municípios da APA, o documento elenca as cuestas e morro-testemunhos como elementos de interesse turístico. Além dos morrotestemunhos, o mapa apresenta áreas com cachoeiras, serras, entre outros.

Apesar dos potenciais turísticos indicados na região, o documento chama a atenção para que essa prática, caso seja incentivada, seja planejada de maneira a não degradar o ambiente ao redor.

O potencial turístico da região é significativo, no entanto seu desenvolvimento dentro do território da APA deve se dar em bases ambientalmente sustentáveis, já que grande parte desse potencial está sobre áreas de grande fragilidade ambiental apresentadas neste diagnóstico. A atividade de turismo surgindo na região, transforma o seu potencial natural em mercadoria que passa então a ser comercializada e consumida. Dessa forma, a falta de planejamento e regulamentação dessa atividade, aliada a falta de planejamento do uso e ocupação do solo, impactam os recursos naturais e comprometem a capacidade de suporte de cada local, podendo transformar o que poderia ser uma alternativa interessante de desenvolvimento socioeconômico para a região da APA em impacto negativo do ponto de vista social e ambiental. (SÃO PAULO, 2011, P. 223) 
Por fim, no volume 2, o estudo de Zoneamento e Planejamento concluiu que o trecho do município de Torre de Pedra que foi analisado está classificado em quatro diferentes categorias, conforme tabela a seguir, com as respectivas descrições e recomendações de uso (Figura 16 e quadro 4) (SÃO PAULOa, 2011, p. 468, 472, 479, 486).
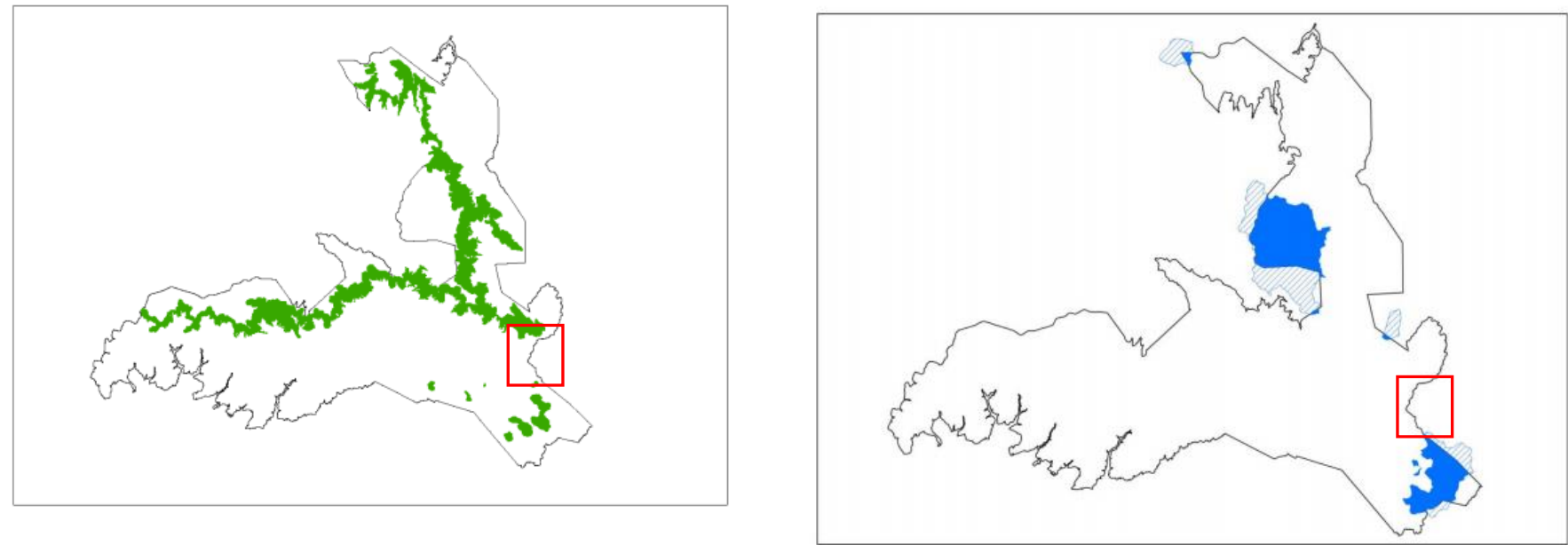

Figura 5/3. ZCPN expandida através de criação de um "buffer" de 250 metros a partir do reverso da Cuesta.

Figura 5/5. Delimitação da Zona de Conservação de Mananciais - ZCM (em azul) e da Área de Conservação de Mananciais - ACM (hachurada).

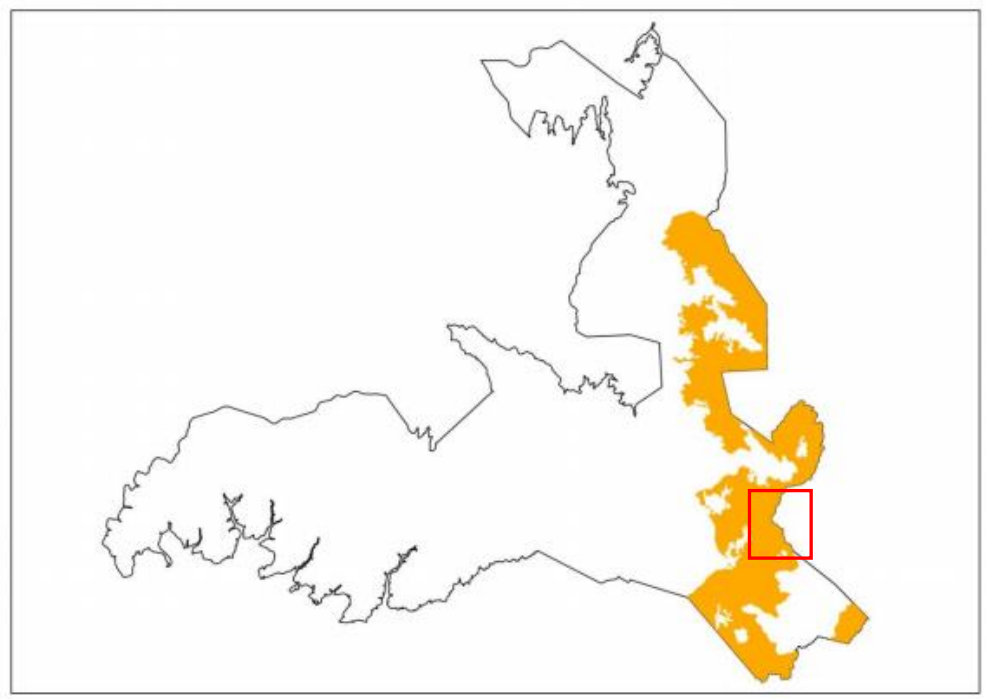

Figura 5/7. Delimitação da Zona de Conservação Hídrica 2

Figura 16: Figuras com a composição do zoneamento de parte do município de Torre de Pedra de acordo com o plano de manejo da APA Corumbataí, Botucatu e Tejupá - Perímetro Botucatu. Fonte: SÃO PAULO, 2011.

Quadro 4: Descrição das zonas e recomendações da APA. Fonte: SÃO PAULOa, 2011

\begin{tabular}{|l|l|l|}
\hline ÁREA & DESCRIÇAO & RECOMENDAÇÃO \\
\hline
\end{tabular}




\begin{tabular}{|c|c|c|}
\hline $\begin{array}{l}\text { Zona de Conservação dos } \\
\text { Mananciais - ZCM }\end{array}$ & $\begin{array}{l}\text { A ZCM é destinada a } \\
\text { conservar e garantir a } \\
\text { qualidade e quantidade das } \\
\text { águas dos } \\
\text { mananciais de } \\
\text { abastecimento público e } \\
\text { restringir as atividades ou } \\
\text { obras que } \\
\text { potencializem o risco de } \\
\text { erosão do solo e a } \\
\text { contaminação dos recursos } \\
\text { hídricos. }\end{array}$ & $\begin{array}{l}\text { Admissíveis atividades ou } \\
\text { usos que não impliquem } \\
\text { em: } \\
\text {-Alteração da qualidade e } \\
\text { a quantidade dos recursos } \\
\text { hídricos superficiais e } \\
\text { subterrâneos a serem } \\
\text { utilizados para } \\
\text { abastecimento público. }\end{array}$ \\
\hline $\begin{array}{l}\text { Zona de Conservação do } \\
\text { Patrimônio Natural - } \\
\text { ZCPN }\end{array}$ & $\begin{array}{l}\text { A ZCPN é destinada a } \\
\text { conservar as áreas mais } \\
\text { íntegras e proteger as áreas } \\
\text { mais frágeis, restringindo a } \\
\text { ocupação e a utilização } \\
\text { dos recursos naturais, de } \\
\text { forma a garantir a proteção } \\
\text { e a conservação do } \\
\text { patrimônio natural, } \\
\text { representado pelos } \\
\text { atributos geomorfológicos } \\
\text { que formam paisagens de } \\
\text { grande beleza cênica, com } \\
\text { trechos de vegetação } \\
\text { nativa bem conservada } \\
\text { servindo de importantes } \\
\text { refúgios da biodiversidade } \\
\text { regional. A ZCPN } \\
\text { compreende as Cuestas } \\
\text { Basálticas, cabeceiras dos } \\
\text { cursos d'água que drenam } \\
\text { para o interior da APA, } \\
\text { mesas e morro- } \\
\text { testemunhos, e a } \\
\text { diversidade biológica } \\
\text { ocorrente. }\end{array}$ & $\begin{array}{l}\text { Admissíveis atividades ou } \\
\text { usos que não impliquem } \\
\text { em: } \\
\text {-Supressão, fragmentação } \\
\text { ou degradação da } \\
\text { vegetação nativa em } \\
\text { qualquer } \\
\text { estagio de regeneração; } \\
\text {-Comprometimento da } \\
\text { estabilidade do relevo das } \\
\text { cuestas, morros e mesas } \\
\text { testemunhos e } \\
\text { descaracterização do } \\
\text { conjunto paisagístico por } \\
\text { eles formado; } \\
\text {-Assoreamento ou } \\
\text { poluição dos recursos } \\
\text { hídricos superficiais e } \\
\text { subterrâneos } \\
\text { dentro da zona ou áreas de } \\
\text { drenagem. } \\
\text { Permitidos } \\
\text {-Atividades turísticas de } \\
\text { educação e } \\
\text { conscientização ambiental, } \\
\text { de contemplação } \\
\text { da paisagem; } \\
\text {-Implantação de Infra- } \\
\text { estrutura de turismo e } \\
\text { esporte de aventura, tais } \\
\text { como trilhas com veículos } \\
\text { off-road, motocicletas, vôo } \\
\text { livre, entre outros, desde } \\
\text { que as atividades estejam } \\
\text { normatizadas e em áreas } \\
\text { licenciadas; }\end{array}$ \\
\hline
\end{tabular}




\begin{tabular}{|l|l|l|}
\hline Zona de Conservação & A Zona de Conservação & Admissíveis atividades ou \\
Hídrica 2 (ZCH2) & Hídrica 2 é destinada à & usos que não impliquem \\
proteção e a conservação & em: \\
da qualidade e quantidade & -Degradação do solo e \\
das águas superficiais e & aceleração dos processos \\
subterrâneras com ênfase & erosivos e alteração da \\
& no Aquífero Guaraní, em & qualidade e quantidade dos \\
& áreas com alta fragilidade & recursos hídricos \\
erosiva e declividade & superficiais e subterrâneos. \\
& acentuada. As ações & Permitidos \\
& relacionadas ànzona visam & -Atividades \\
minimizar processos & agrossilvopastoris com \\
& erosivos, assoreamento & adoção de práticas \\
& dos corpos hídricos e & adequadas de conservação \\
& contaminação das águas & e manejo do solo \\
& superficiais e do Aquífero & \\
& Guarani. \\
\hline
\end{tabular}

Além desse zoneamento, o plano de manejo definiu áreas e pontos relacionados ao interesse histórico, à recuperação de áreas degradadas e ao potencial turístico (SMA, 2011). O município de Torre de Pedra está relacionado como Área de Potencial Interesse Turístico (APIT), que segundo o documento, “compreende também localidades pontuais e trechos de interesse paisagístico com grande potencial para atividades turísticas recreativas e de contemplação" (SÃO PAULO, 2011, p. 462). São destacados como exemplos o morro-testemunho Torre de Pedra e o Morro Agudo.

A pesquisa é apontada como uma diretriz crucial do plano de manejo da APA, tanto para atualizar as informações do plano quanto para indicar novas lacunas de conhecimento, auxiliando no desenvolvimento de atividades viáveis tanto do ponto de vista ambiental quanto econômico (quadro 5). 
Quadro 5: Quadro de diretrizes para atividades de pesquisa na APA Corumbataí, Botucatu e Tejupá - Perímetro Botucatu. Fonte: SÃO PAULOa, 2011.

PESQUISA

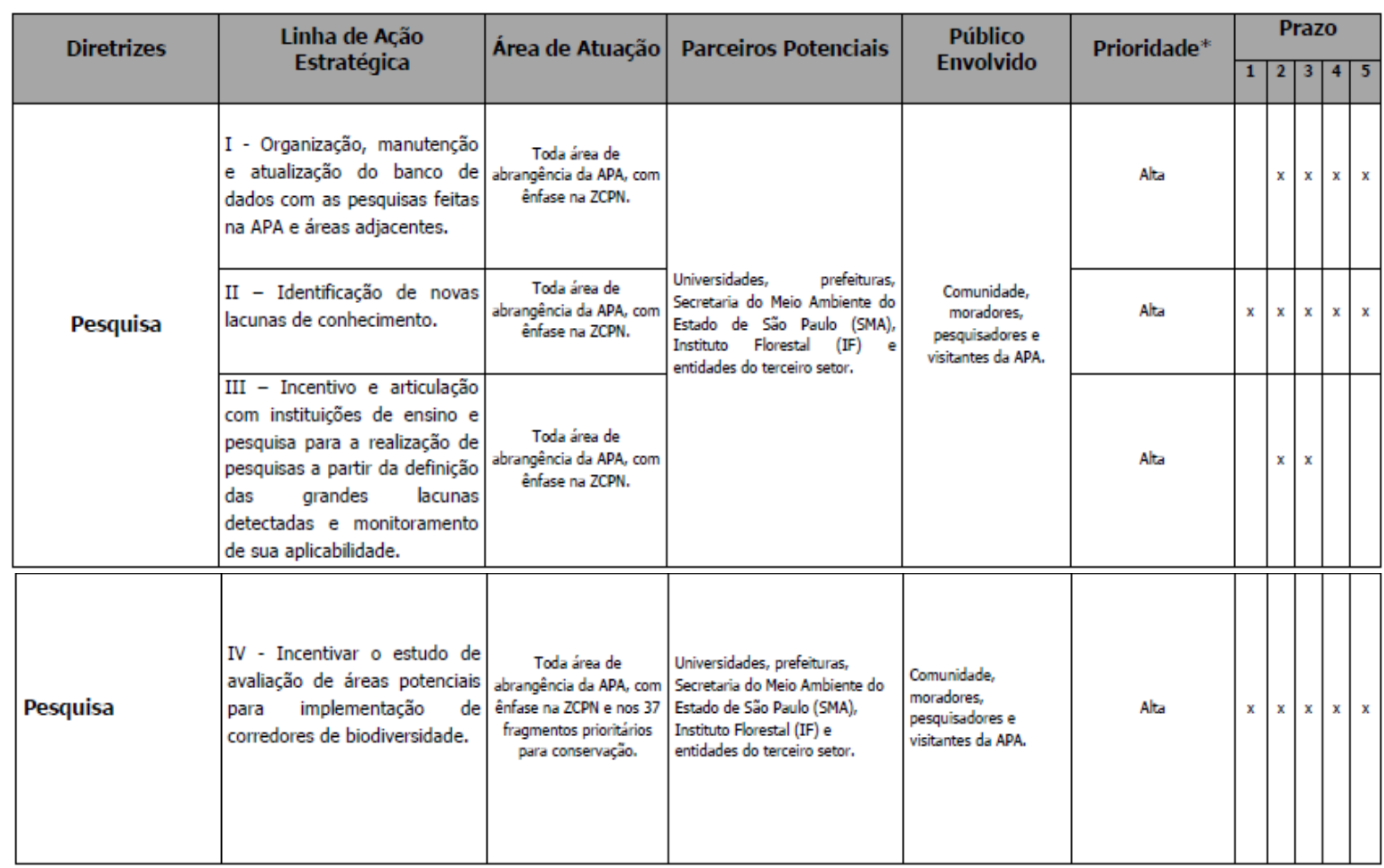

Dessa forma, o Plano de Manejo apresenta um panorama completo de parte do município de Torre de Pedra, indicando tipos de usos do solo em convergência com outros estudos sobre a área (FARIA, 2014). Além disso, a indicação da necessidade de realizar mais pesquisas na região de toda a APA reforça a importância de pesquisas como esta, que abrange outros aspectos do município de Torre de Pedra. Por isso, esse Plano de Manejo foi considerado um estudo bastante pertinente e necessário para o planejamento dos municípios envolvidos. Indica-se, contudo, a necessidade de atualização de seus dados, já que o SNUC prevê que o plano de manejo das UC é um processo contínuo e deve ser atualizado regularmente.

\section{1.b Situação de conservação do morro-testemunho}

Por meio da avaliação da literatura prévia sobre a área de estudos e observações em trabalhos de campo, realizou-se um levantamento sobre a situação do estado de conservação do morro-testemunho Torre de Pedra. FARIA, 2014, indicou atividades 
degradadoras e má conservação do morro-testemunho Torre de Pedra, com pichações e lixo em seu entorno (Figura 18). Essa situação foi mantida conforme os trabalhos de campo realizados para essa pesquisa e, além disso, foram registradas imagens de atividades potencialmente degradadoras, como silvicultura e mineração de areia, nos trabalhos de campo e na literatura (mapa 4).

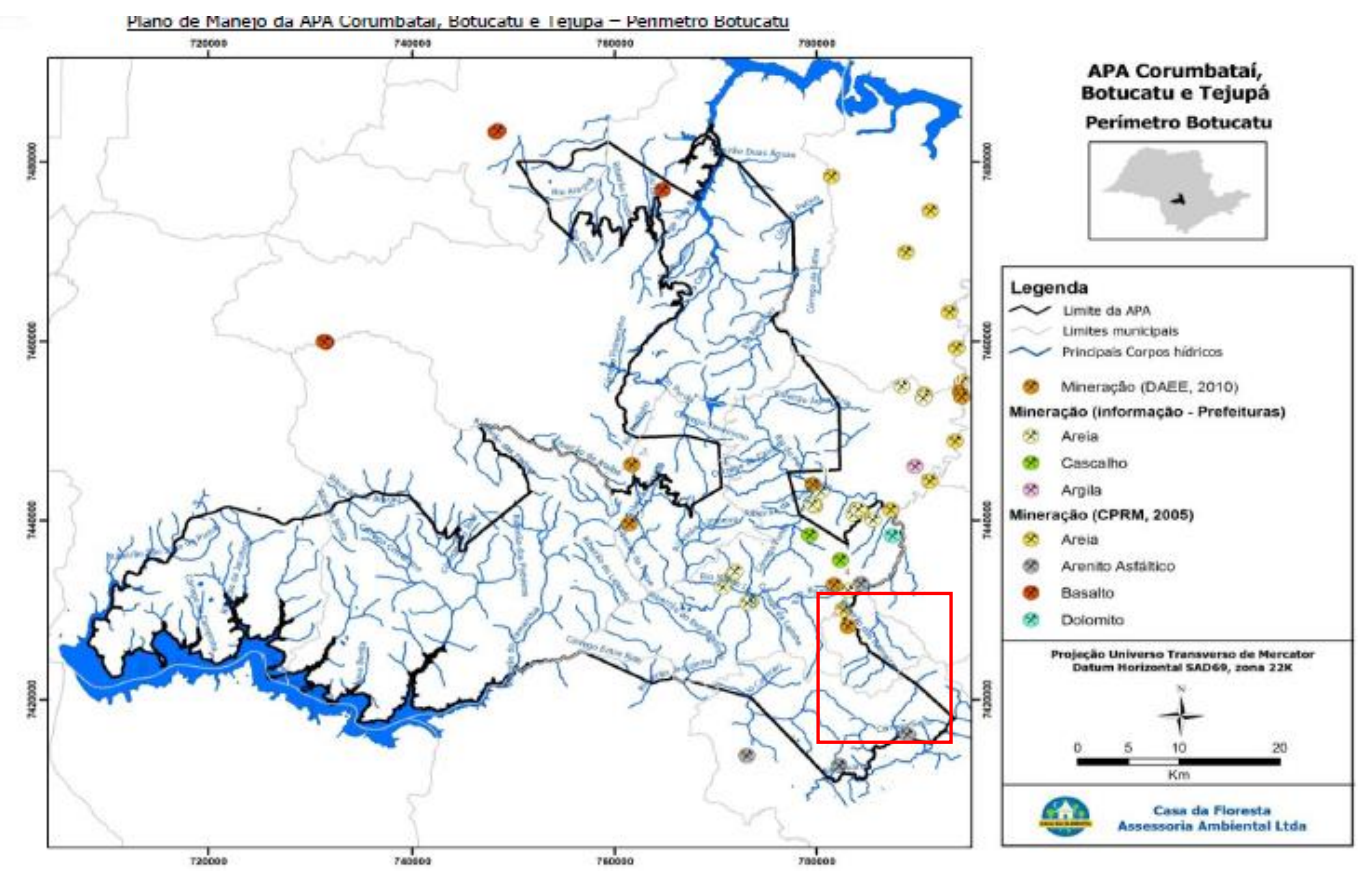

Mapa 4: Mapa de atividades de mineração na APA Corumbataí, Botucatu e Tejupá - Perímetro Botucatu. Destaque em vermelho para o município de Torre de Pedra. Fonte: São Paulo, 2011. 


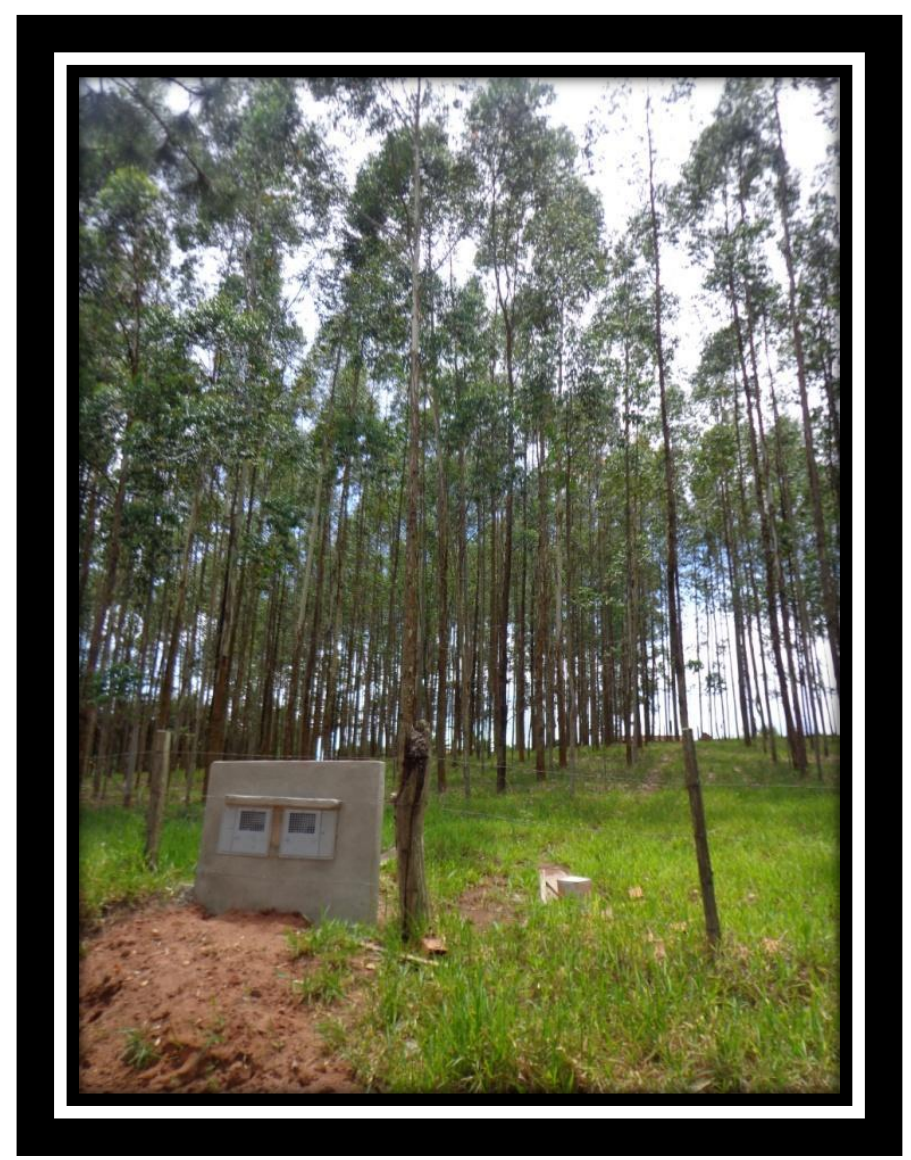

Figura 17: Silvicultura nas proximidades do morro-testemunho Torre de Pedra. Fotografia de 2013. Fonte: FARIA, 2014.

Nos trabalhos de campo, constatou-se a má conservação e degradação recente da região do entorno do morro-testemunho Torre de Pedra (Figura 18). 


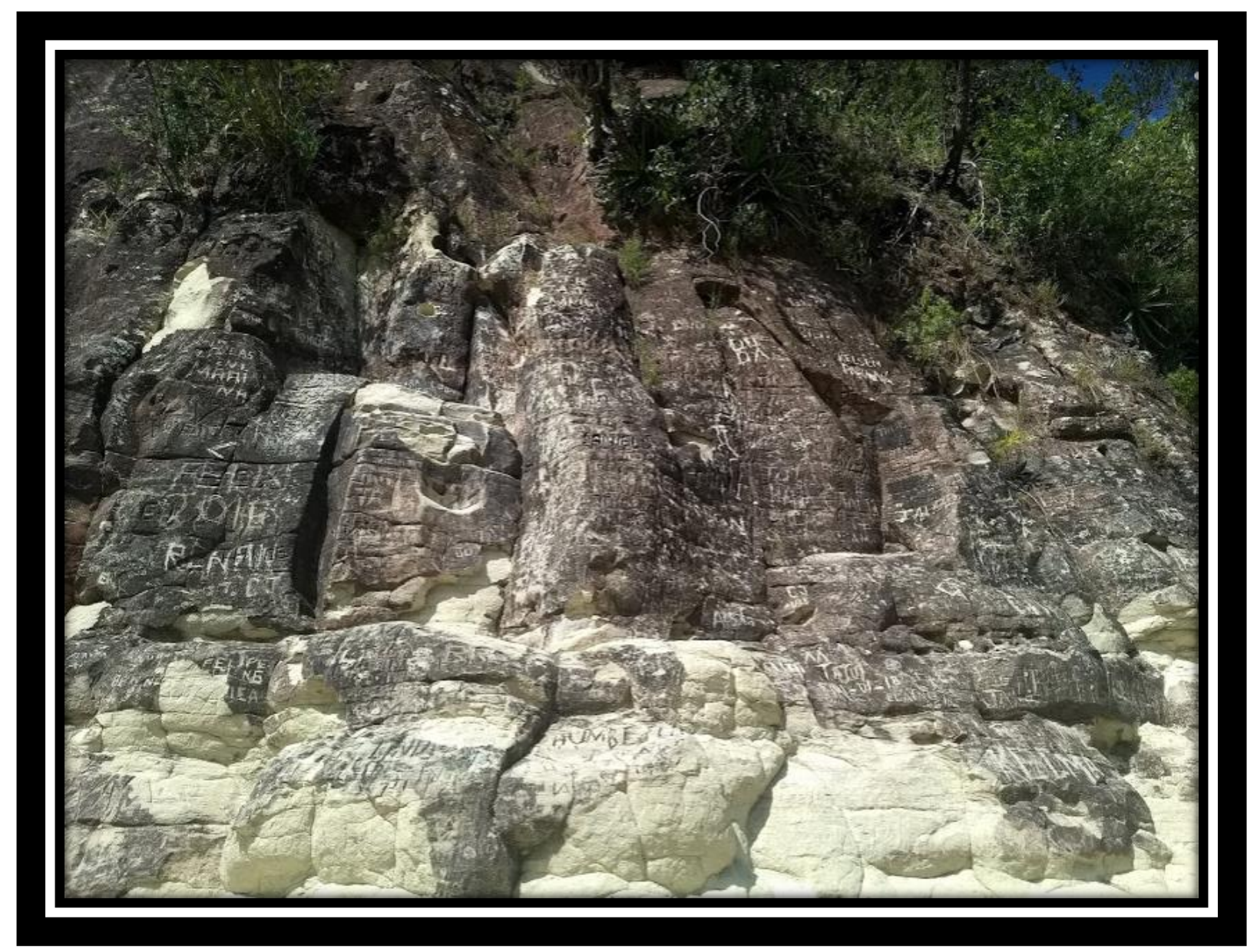

Figura 18: Degradação no sopé do morro-testemunho Torre de Pedra. Foto: Jéssica Vieira de Faria, 2018.

Além das situações apresentadas anteriormente, há registros de áreas de pastagem que encontram-se degradadas, conforme Figura 19, com sinais de pisoteio em terrenos íngremes e identificação de ravinas segundo o volume 1 (diagnóstico ambiental) do plano de manejo. 


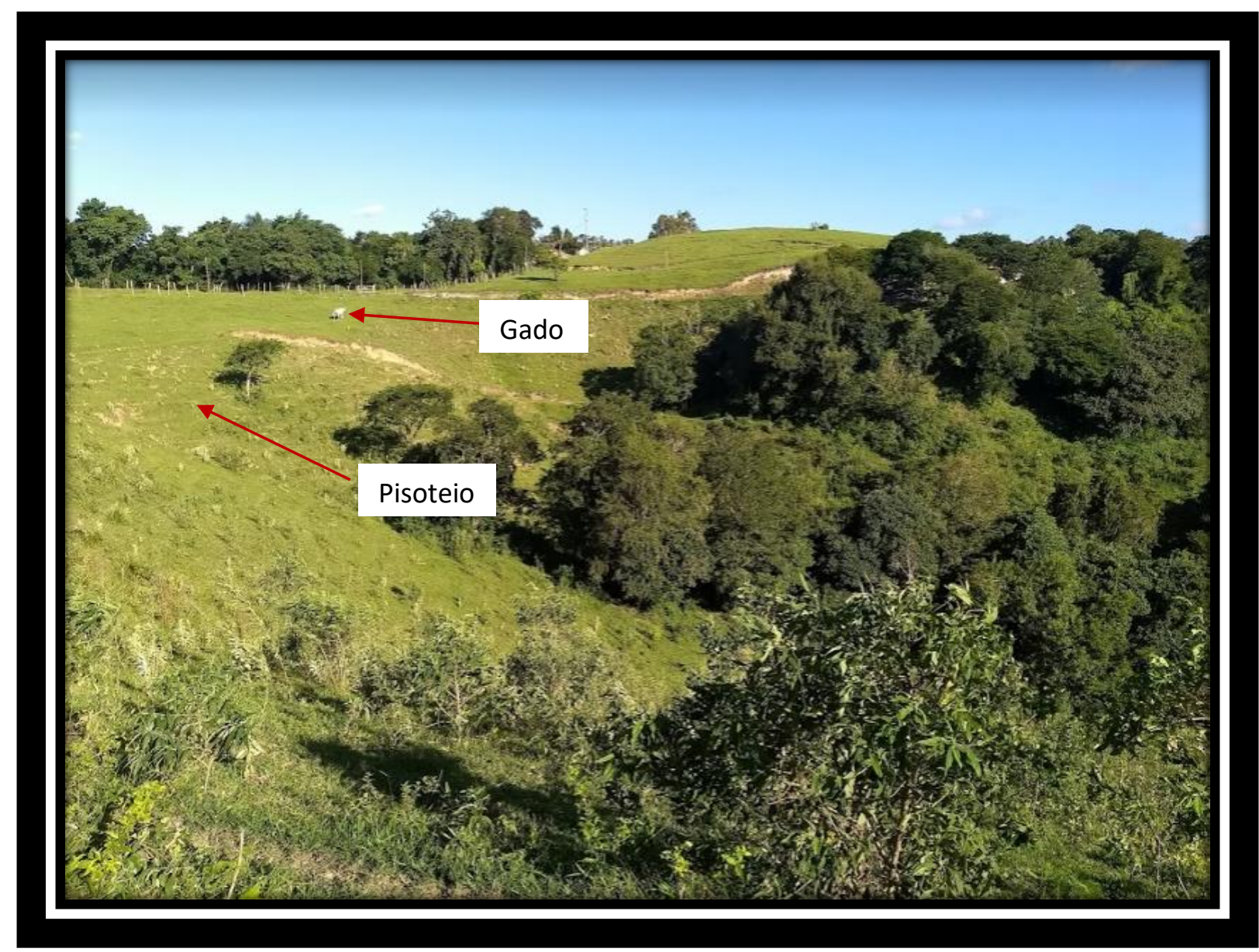

Figura 19: Pisoteio em área de pastagem em terreno íngreme no espigão da Areia Branca, entre os municípios de Torre de Pedra e Guareí. Foto: Jéssica Vieira de Faria, 2018. 


\subsection{Trabalho de campo}

Os trabalhos de campos foram realizados em diversas datas, com anotações, conversas com moradores locais e visitas à prefeitura para levantamento de dados primários. Também foi considerado o trabalho de FARIA, 2014. Contudo, foram sistematizados, a título de descrição, os dois últimos trabalhos de campo realizados, em duas datas, com diferentes objetivos:

1) Realizado previamente para reconhecimento da área de estudo $\mathrm{e}$ levantamento de dados primários, principalmente sobre hidrografia e estado de conservação ambiental da área de estudo;

2) Averiguação da modelagem de dados após o mapeamento síntese.

\section{2.a Primeiro trabalho de campo}

O primeiro trabalho de campo foi realizado em 3 de fevereiro de 2018, sábado. As condições climáticas estavam estáveis, um dia ensolarado com nuvens isoladas, temperatura máxima de $29^{\circ} \mathrm{C}$ e $0 \mathrm{~mm}$ de precipitação. O objetivo do trabalho de campo era reconhecimento da área de estudo e levantamento de dados primários, principalmente sobre hidrografia, uso do solo e estado de conservação ambiental. Os pontos de coleta de dados estão localizados nas zonas central, leste, sul e oeste do município de Torre de Pedra, conforme Figura 20. Os pontos foram escolhidos por serem representativos dos diferentes usos do solo identificados nas imagens de satélite do município. 


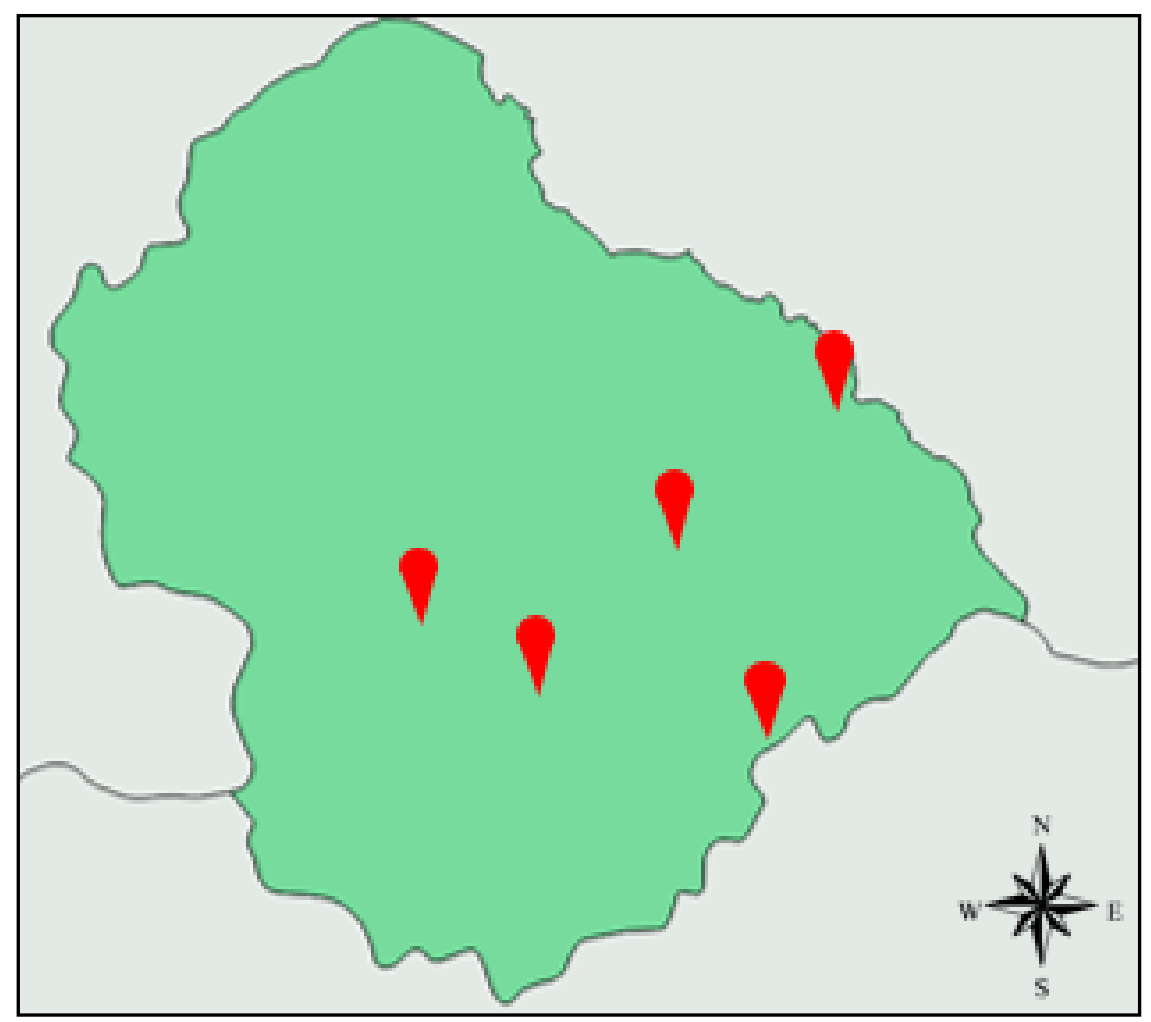

Figura 20: Pontos de coletas de dados do primeiro trabalho de campo no município de Torre de Pedra (SP), sem escala. Foto: Jéssica Vieira de Faria, 2018.

Conforme foi observado em relação à hidrografia da área de estudo, há uma grande quantidade de córregos pequenos, tanto na área rural quanto na entrada da cidade e em seu centro urbano (figuras 21 e 22). Além disso, muitas bicas d'água, algumas próximas ao morro-testemunho Torre de Pedra, que são utilizadas pela população local para consumo. Ao mesmo tempo, foram avistados pontos de despejo direto de esgoto nos córregos locais, conforme figura 23. 


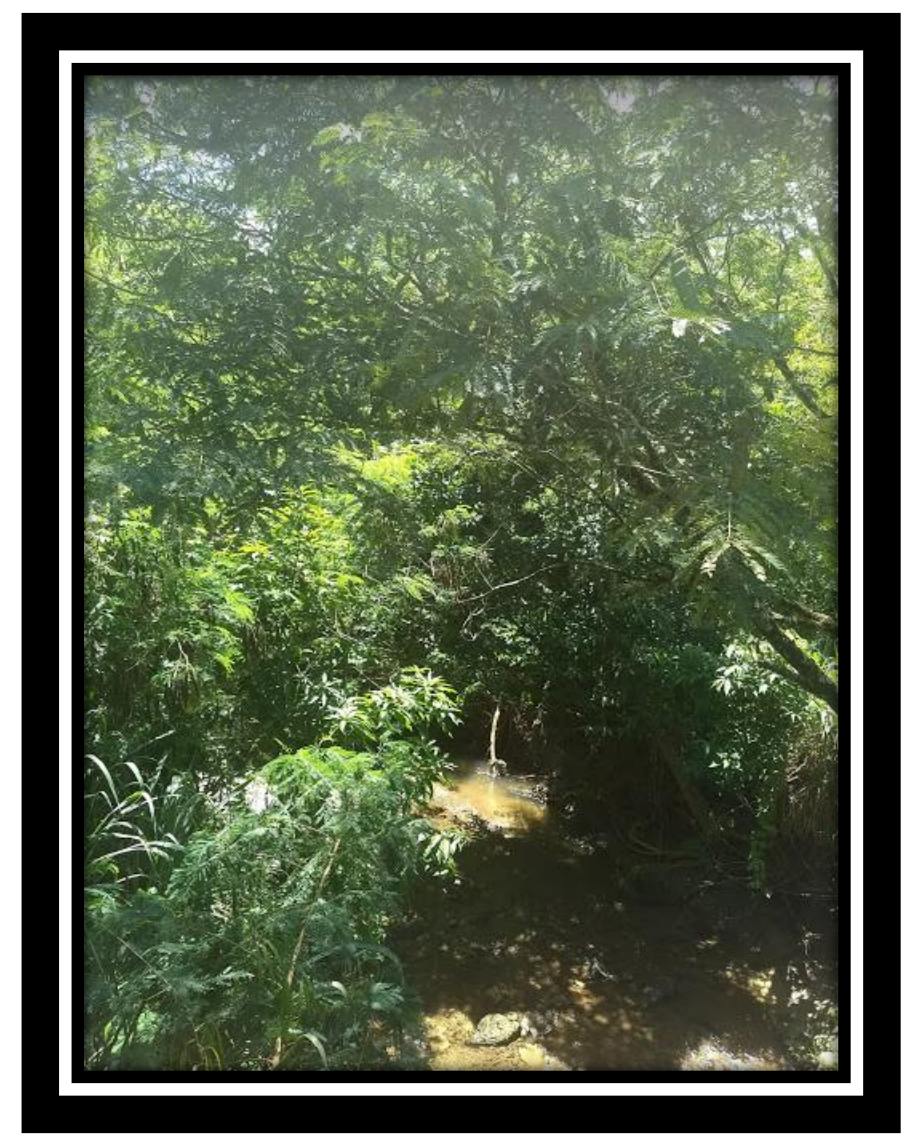

Figura 23: Afluente do rio Feio recebendo despejo direto de esgoto, no município de Torre de Pedra (SP). Essa foto retrata uma área próxima à Rodovia Castelo Branco, com uma pequena vila de aproximadamente 5 casas. Está distante do centro urbano de Torre de Pedra cerca de 8 quilômetros. Foto: Jéssica Vieira de Faria, 2018.

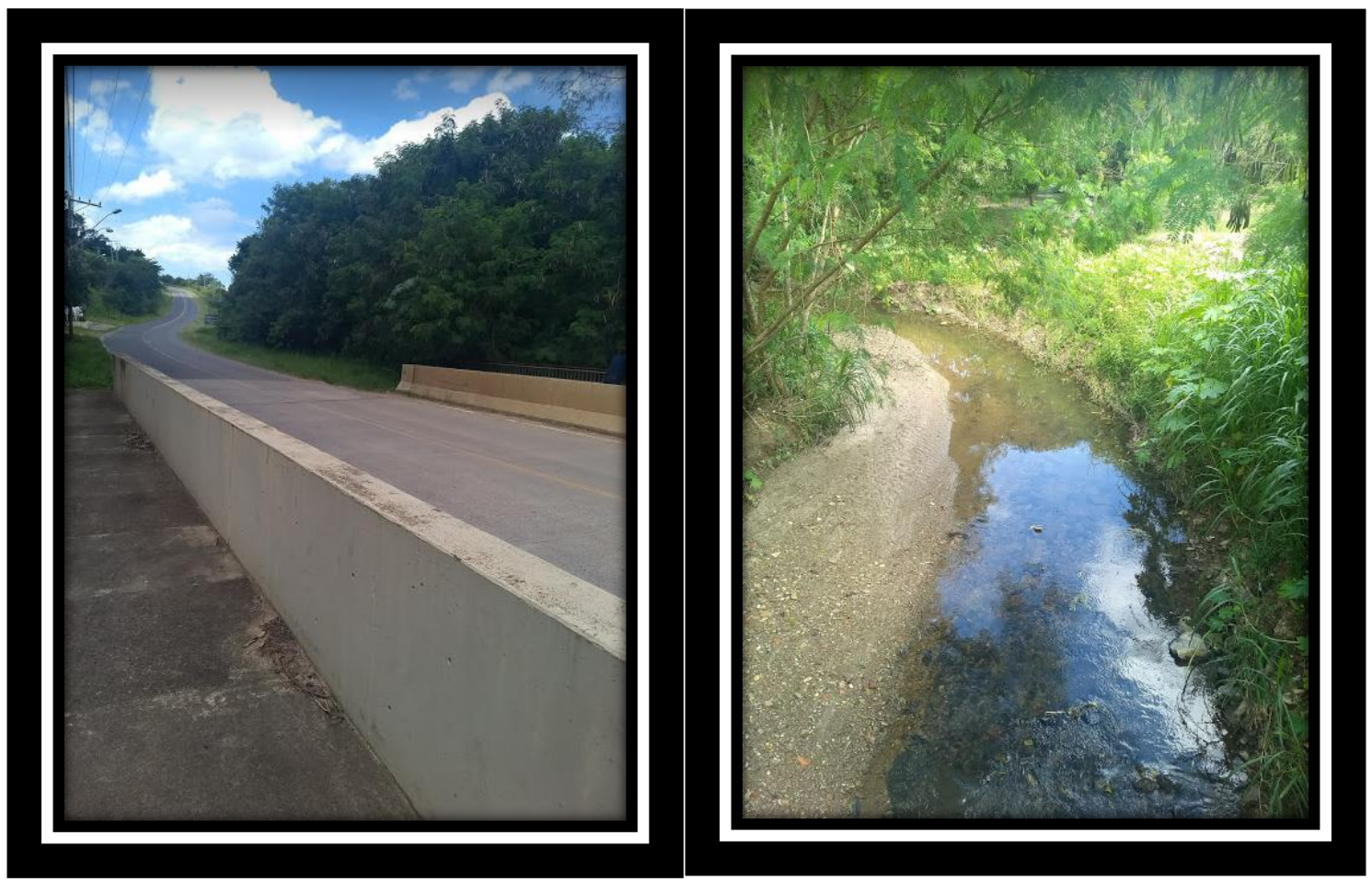

Figuras 21 e 22: À esquerda, ponte na entrada da cidade sobre córrego afluente do Rio Feio. À direita, córrego afluente do Rio Feio e matas ciliares. Foto: Jéssica Vieira de Faria, 2018. 
Durante o trabalho de campo, nos pontos visitados, notou-se que o uso do solo é ocupado predominantemente por pastagens e alguns trechos de mata ciliar ao longo de córregos. Com menos frequência, foram avistadas áreas de silvicultura e plantações (milho e cana). Conforme apresentado em Ross e Moroz, 1997, o relevo da região apresenta colinas com topos amplos (figura 24). Além disso, feições erosivas relacionadas ao uso do solo, como pisoteio por gado e sulcos, foram avistados ao longo do trabalho de campo, principalmente na região do espigão da Areia Branca, entre os município de Torre de Pedra e Guareí (figuras 24 e 25). 


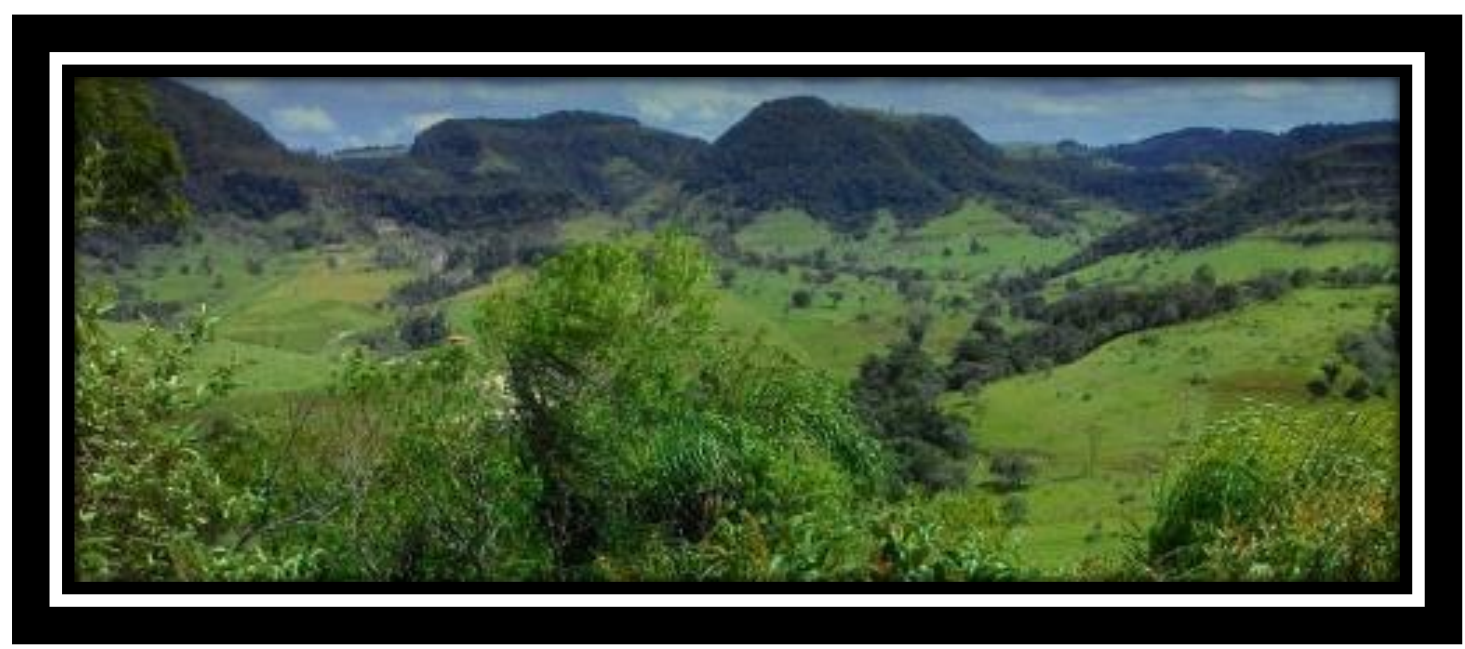

Figura 24: Morros na direção da cuesta vistos a partir do sopé do morrotestemunho Torre de Pedra. Foto: Jéssica Vieira de Faria, 2018.

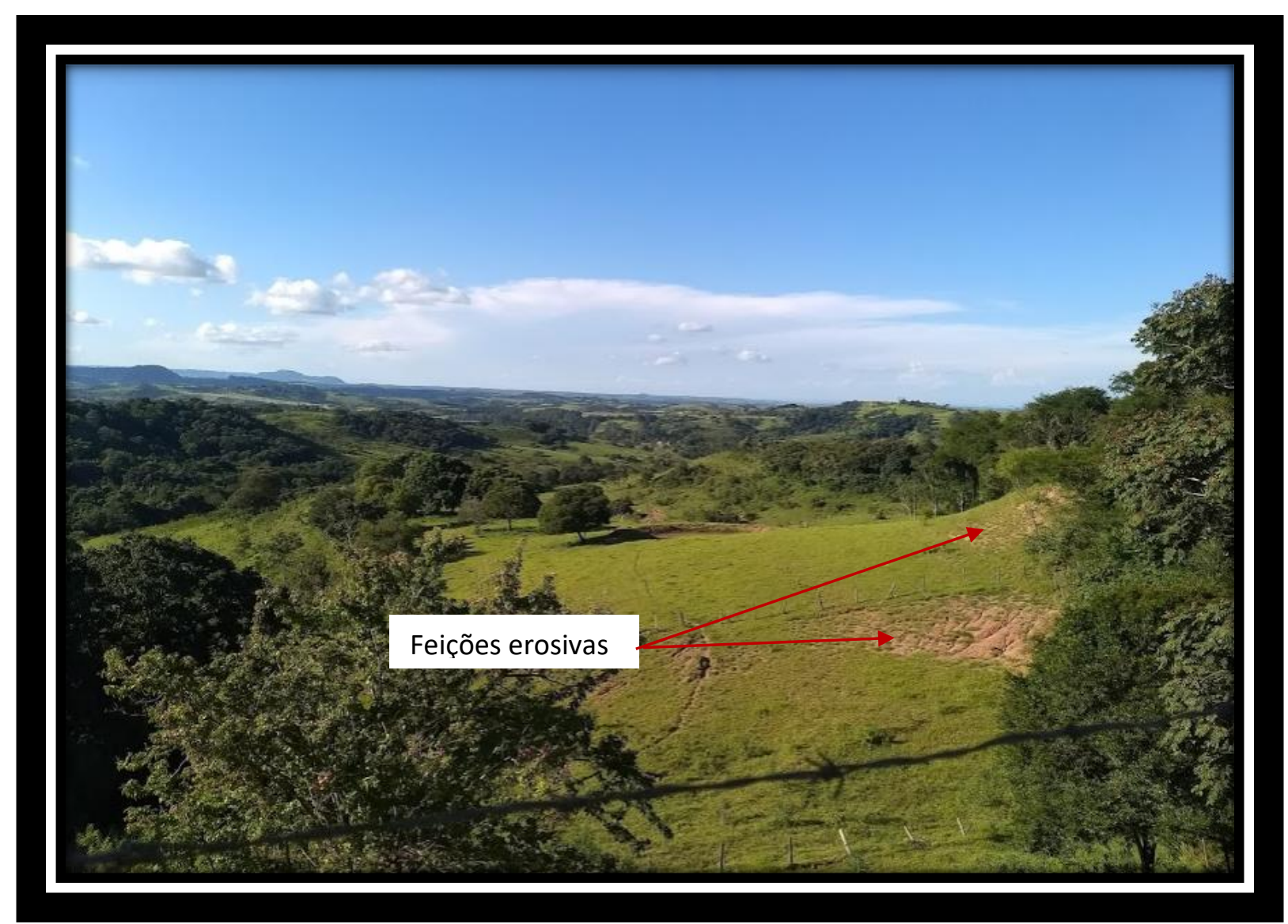

Figura 25: Feições erosivas em terreno íngreme no espigão da Areia Branca, entre os municípios de Torre de Pedra e Guareí. Ao fundo, observa-se o início do reverso da cuesta à esquerda. Foto: Jéssica Vieira de Faria, 2018. 


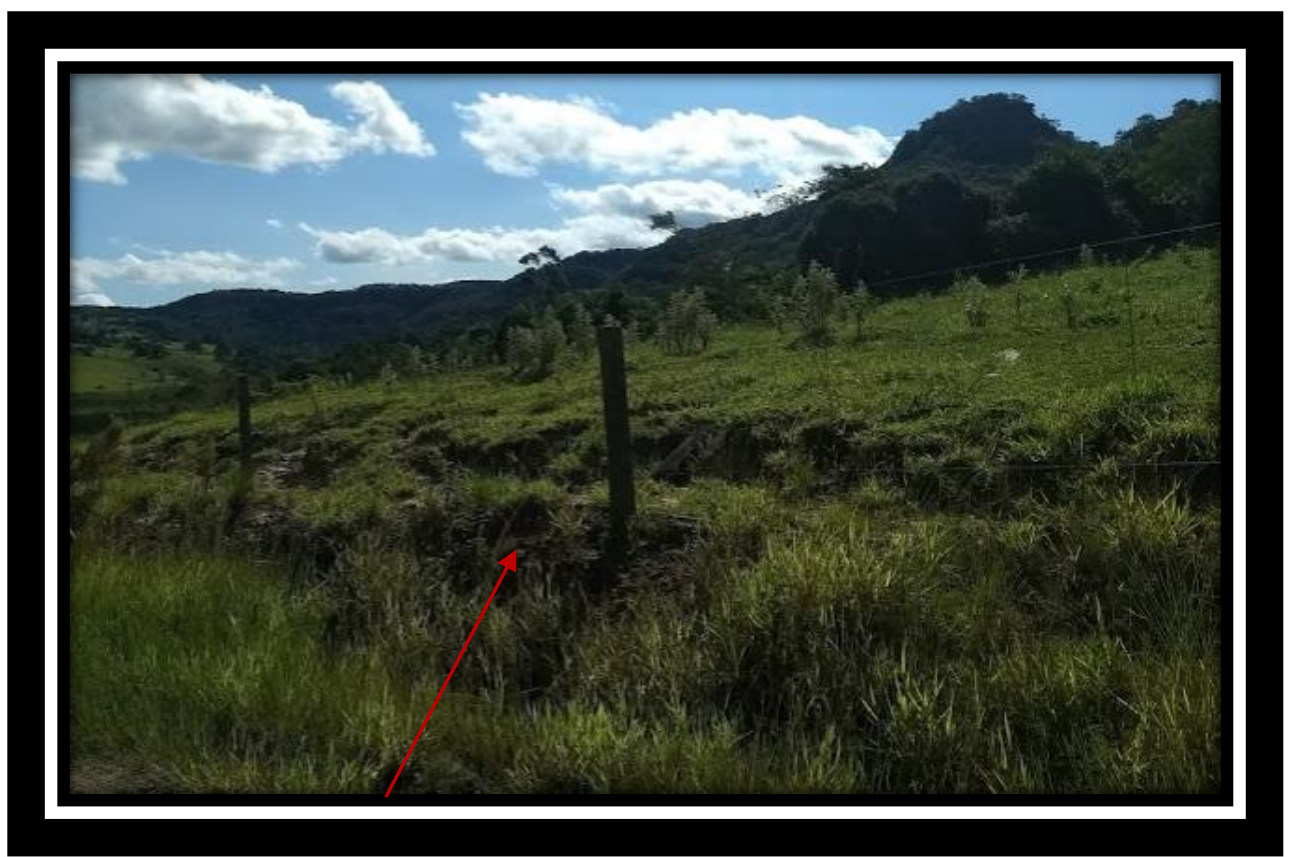

Figura 26:

Erosão do solo ao longo da cerca que delimita o terreno onde fica o Morro Agudo, em Torre de Pedra (SP). Foto: Jéssica Vieira de Faria, 2018 .

No tocante à ocupação urbana, o núcleo urbano municipal é pequeno, cujo zoneamento ocorre como dois bairros principais: centro e conjunto habitacional. O centro urbano fica distante cerca de cinco quilômetros do morro-testemunho Torre de Pedra e Morro Agudo (figura 27).

Figura 27: Centro urbano de Torre de Pedra (SP). Foto: Jéssica Vieira de Faria, 2018.

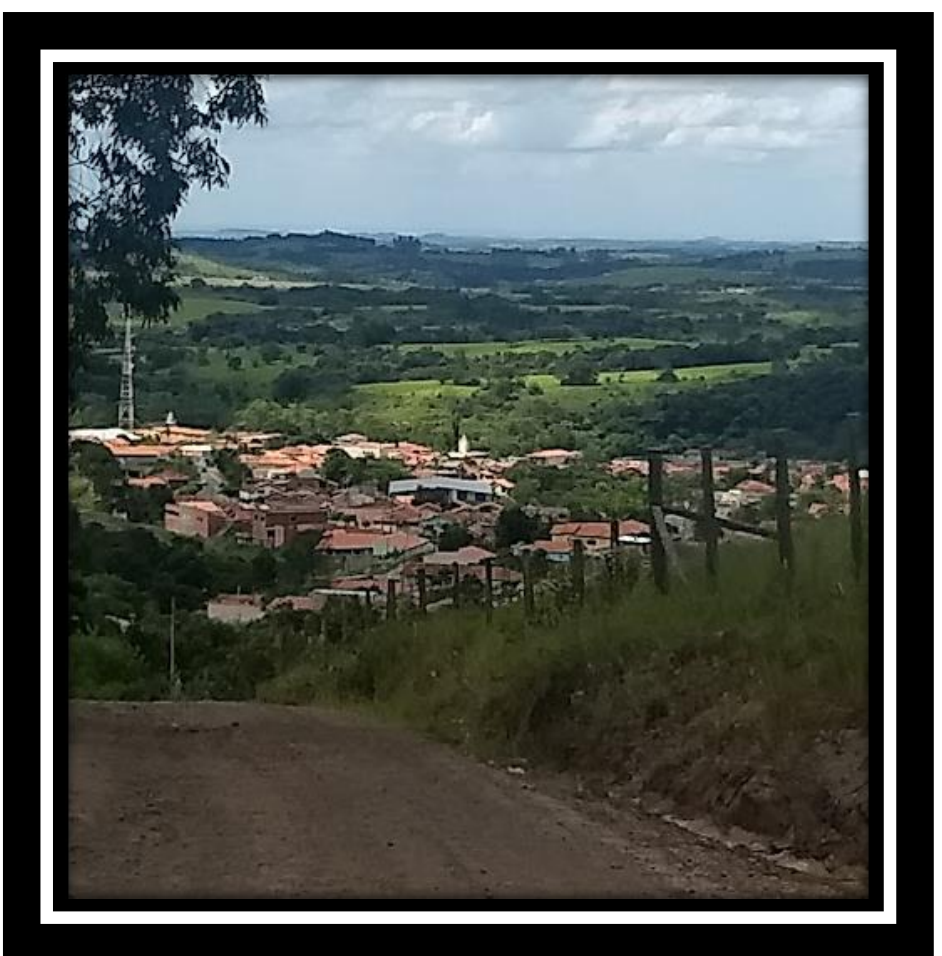


Em relação aos aspectos turísticos, apesar de ser o nome do município, cujo slogan é "Bonita por natureza", não houve, durante os trabalhos de campo, registro de atividades sistematicamente organizadas para visitação do morro-testemunho Torre de Pedra. No dia do primeiro trabalho de campo, apesar de ser um final de semana ensolarado e sem chuva, não foram vistos turistas na região (confirmado pelo relato de um morador local) (figuras 29 e 30 ).

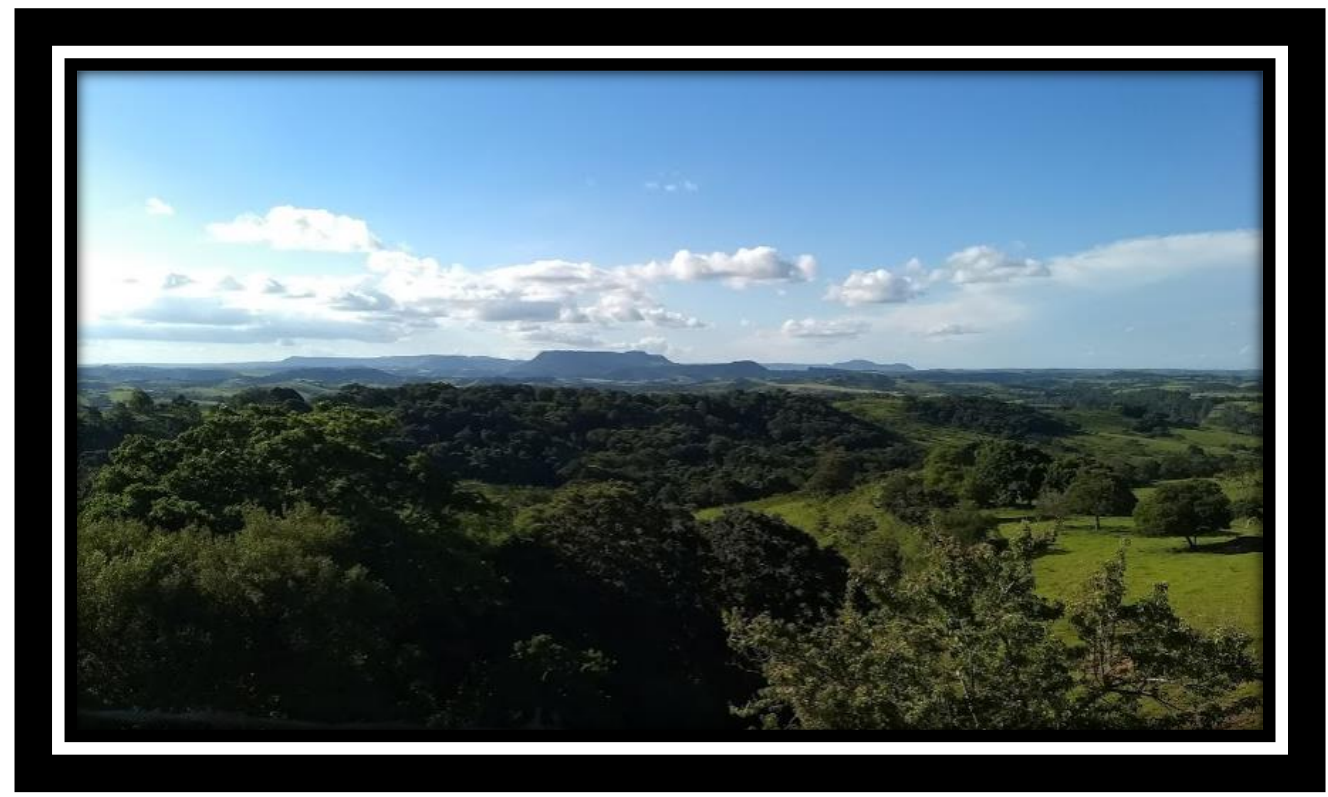

Figura 28: Vista da cuesta a partir do espigão da Areia Branca, divisa entre os municípios de Torre de Pedra e Guareí. Foto: Jéssica Vieira de Faria, 2018.

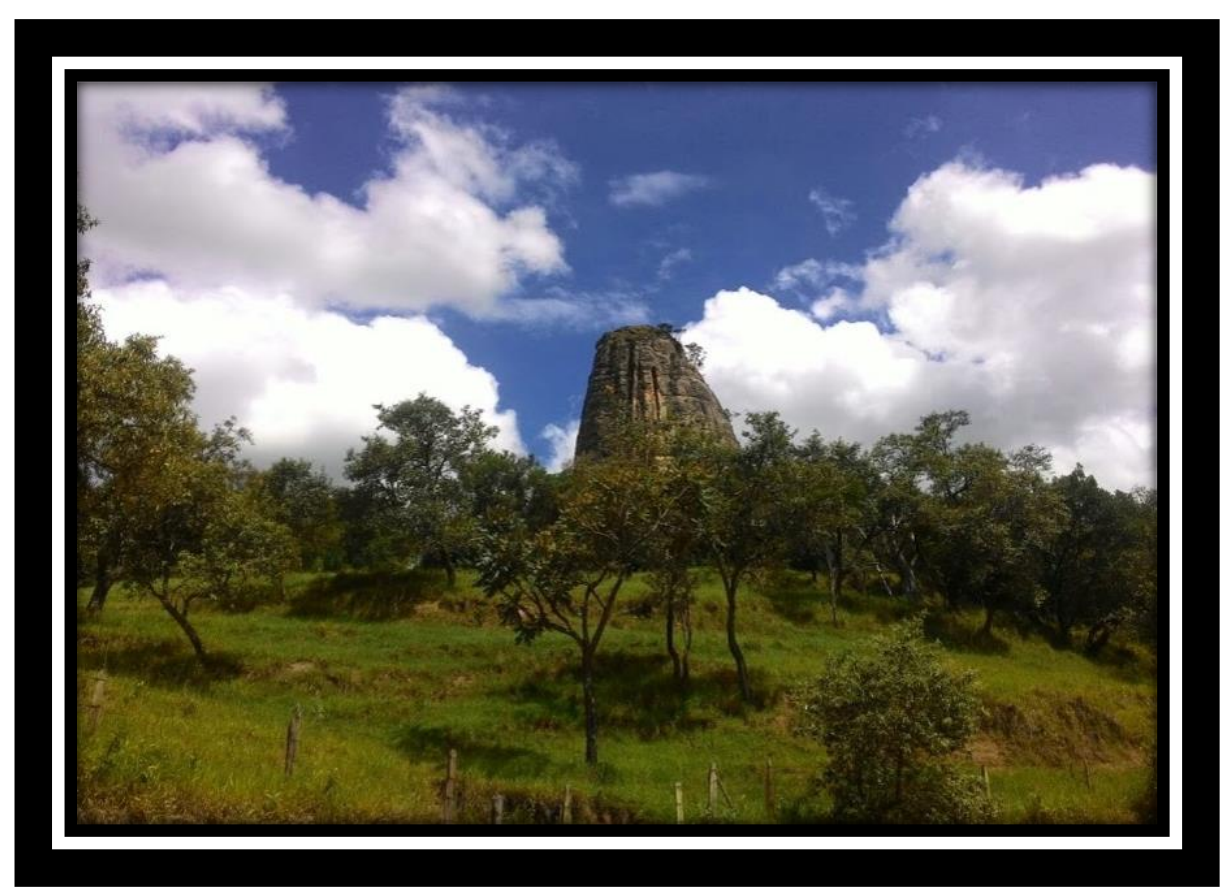

Figura 29: Morro-testemunho Torre de Pedra. Foto: Jéssica Vieira de Faria, 2018. 
Conforme mencionado anteriormente, contatou-se a má conservação e degradação recente da área do entorno do morro-testemunho Torre de Pedra (figura 30).

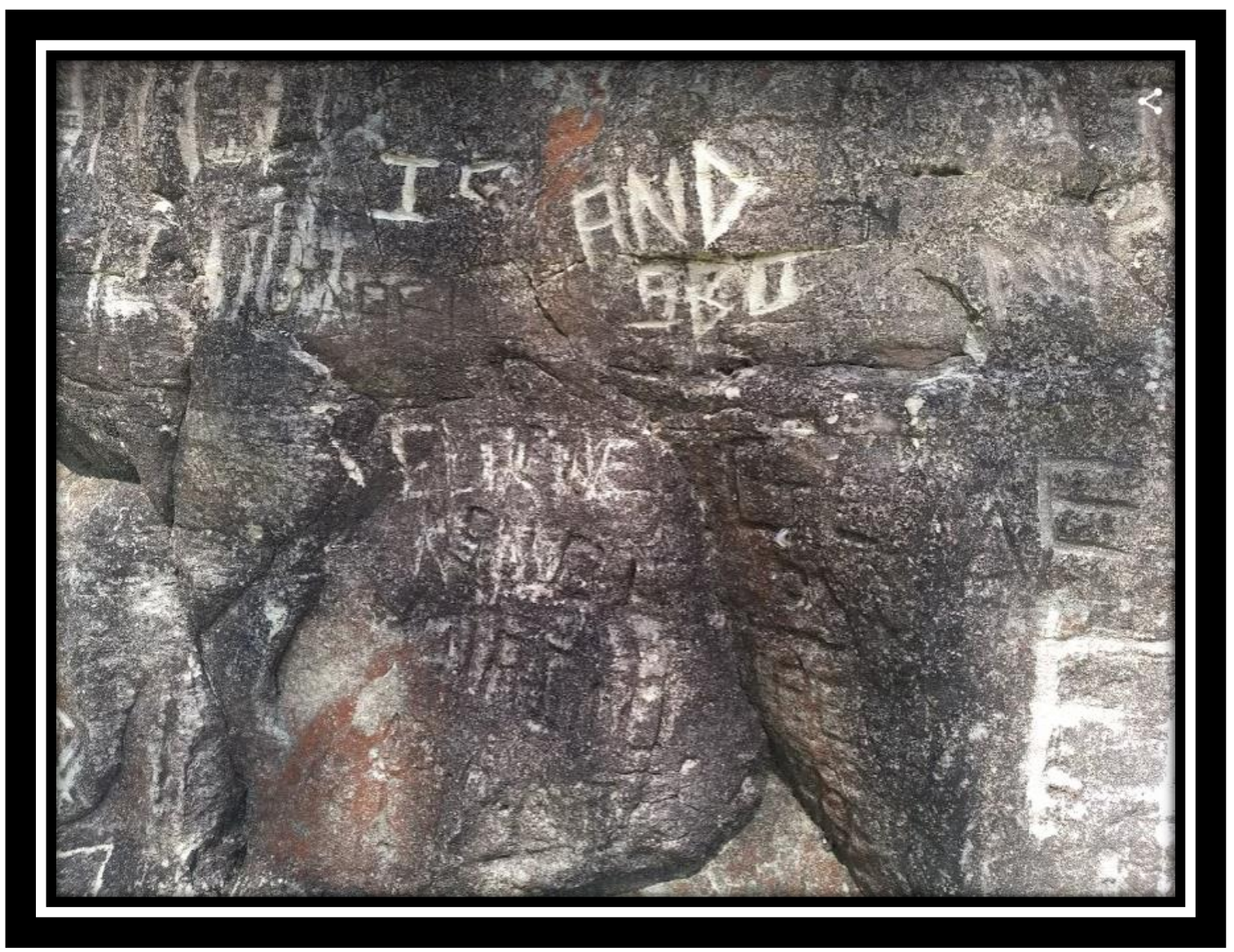

Figura 30: Detalhe do morro-testemunho Torre de Pedra. É possível ver pichações e marcas ao longo de todo o morro. Foto: Jéssica Vieira de Faria, 2018.

Ao compararmos imagens históricas de Torre de Pedra (em 1940) com as imagens do trabalho de campo (em 2018), percebe-se que a mata localizada ao entorno do morrotestemunho permanece preservada (figuras 32 e 33). É possível supor que o entorno do morro era ocupado por pastagens, assim como é atualmente.

Além do uso do solo, as estradas vicinais continuam sendo as mesmas desde a primeira fotografia, tirada em 1940. Assim como na foto aérea de 1940, a mata adjacente ao morro-testemunho encontra-se preservada até hoje, aparentemente é mais densa nos dias atuais. Também é possível visualizar, na foto aérea de 1940, estradas vicinais mantidas até hoje e predomínio de áreas de pastagem no entorno. A foto atual apresenta pastagens com sinais de pisoteio em primeiro plano. 

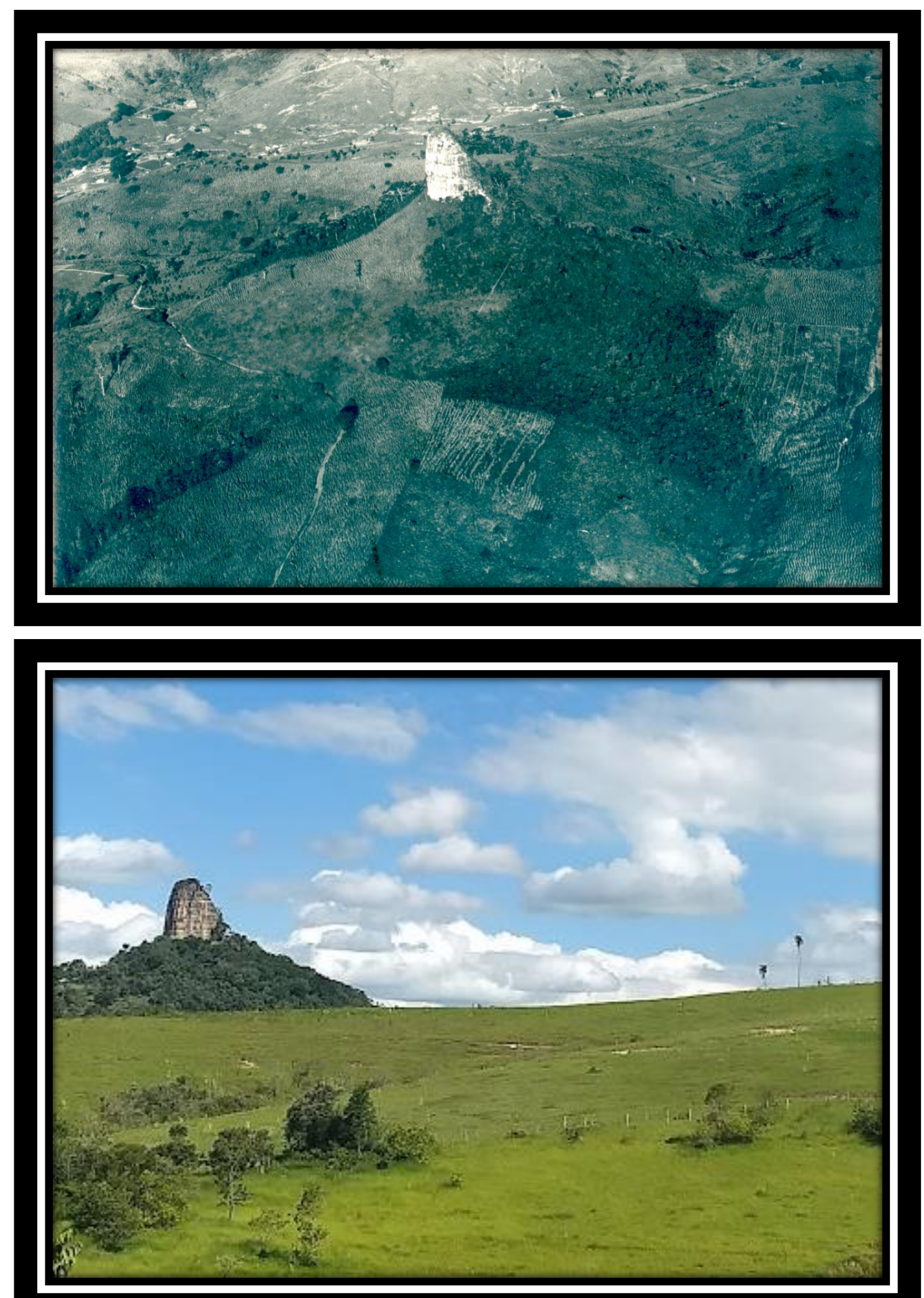

Figuras 31 e 32: Fotos do morro-testemunho Torre de Pedra e seu entorno. Acima, foto aérea de 1940; embaixo, foto de 2018. FONTE: ARQUIVO PÚBLICO DO ESTADO DE SÃO PAULO, 1940; Jéssica Vieira de Faria, 2018. 


\section{$\underline{\text { 5.2.b Segundo trabalho de campo }}$}

O último trabalho de campo foi realizado em 19 de maio de 2018, sábado. As condições climáticas estavam instáveis, céu nublado e tempo chuvoso, temperatura máxima de $19^{\circ} \mathrm{C}$ e $10 \mathrm{~mm}$ de precipitação. O objetivo do trabalho de campo era a averiguação dos dados após o mapeamento síntese baseado nos dados levantados pela literatura e pelo primeiro trabalho de campo (geomorfologia, pedologia e uso do solo). Os pontos de coleta de dados eram localizados nas zonas norte e leste do município de Torre de Pedra, conforme figura 33.

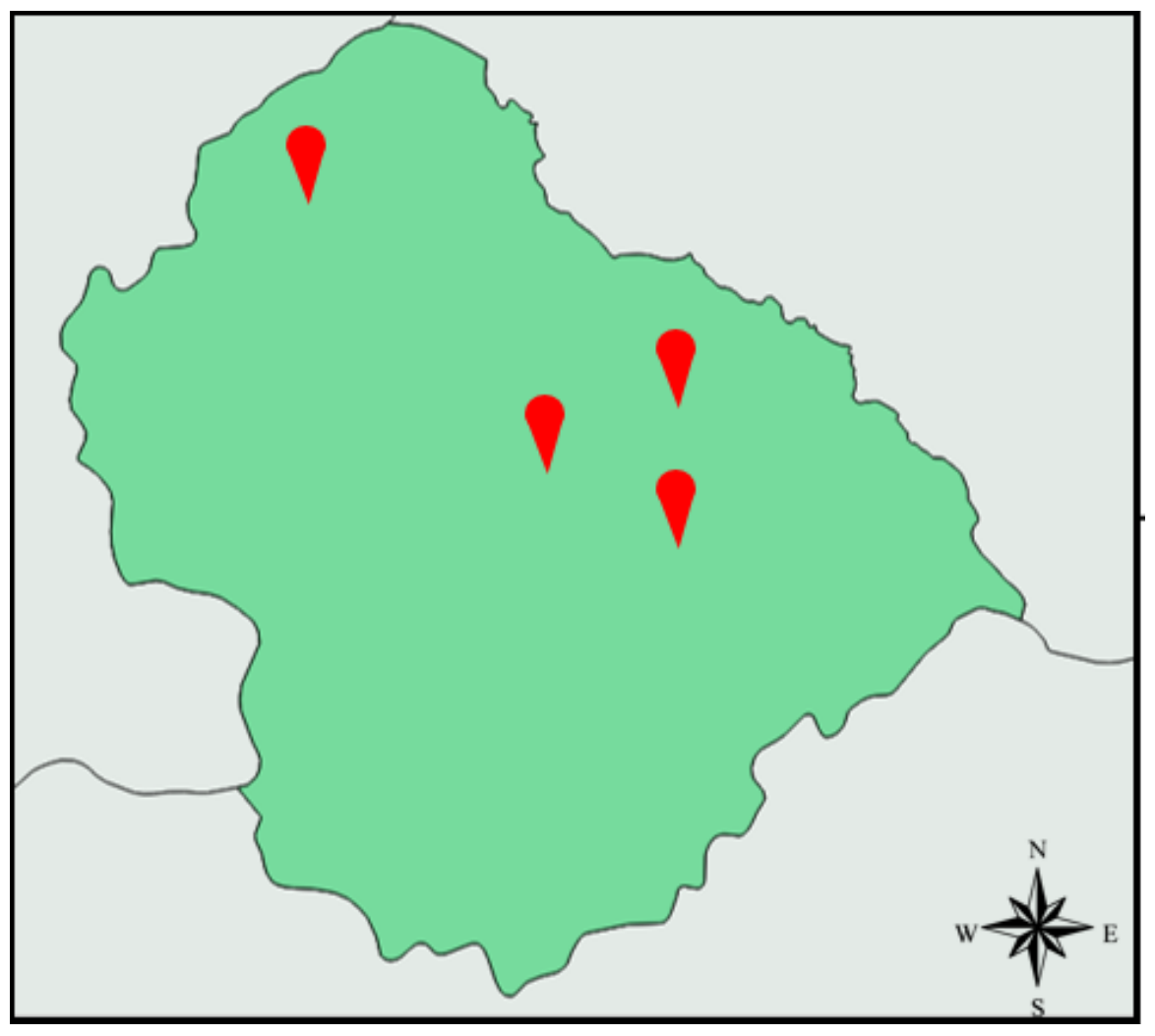

Figura 33: Pontos de coletas de dados do segundo trabalho de campo. Foto: Jéssica Vieira de Faria, 2018.

Em relação aos parâmetros geomorfológicos e pedológicos, as indicações do mapeamento foram confirmadas, com formas de relevos de colinas de topos convexos e eventuais declives mais acentuados, principalmente próximo ao morro-testemunho Torre de Pedra e ao Espigão da Areia Branca, na divisa com o município de Guareí (SP). 


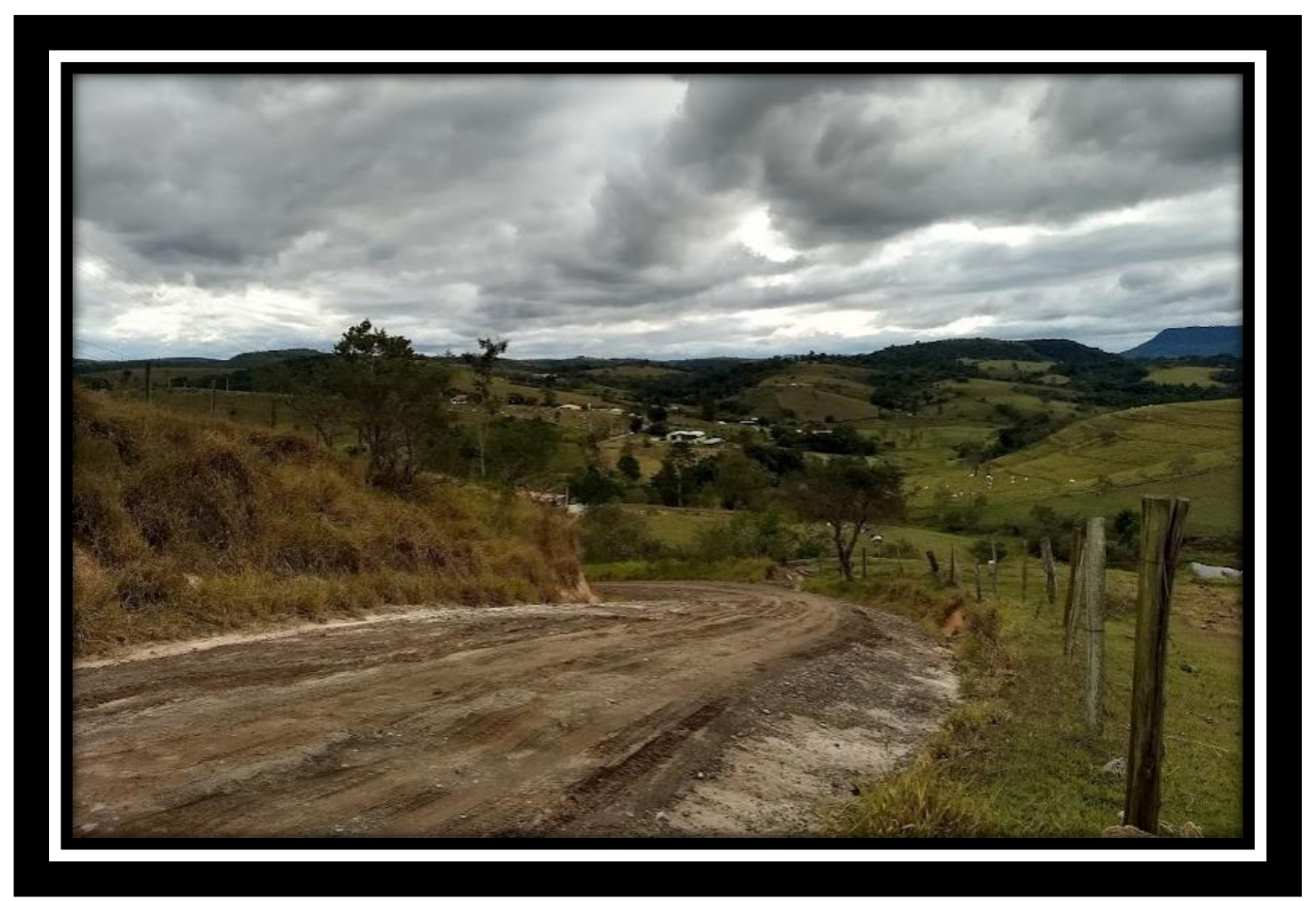

Figura 34: Colinas de topos convexos na zona nordeste do município de Torre de Pedra.

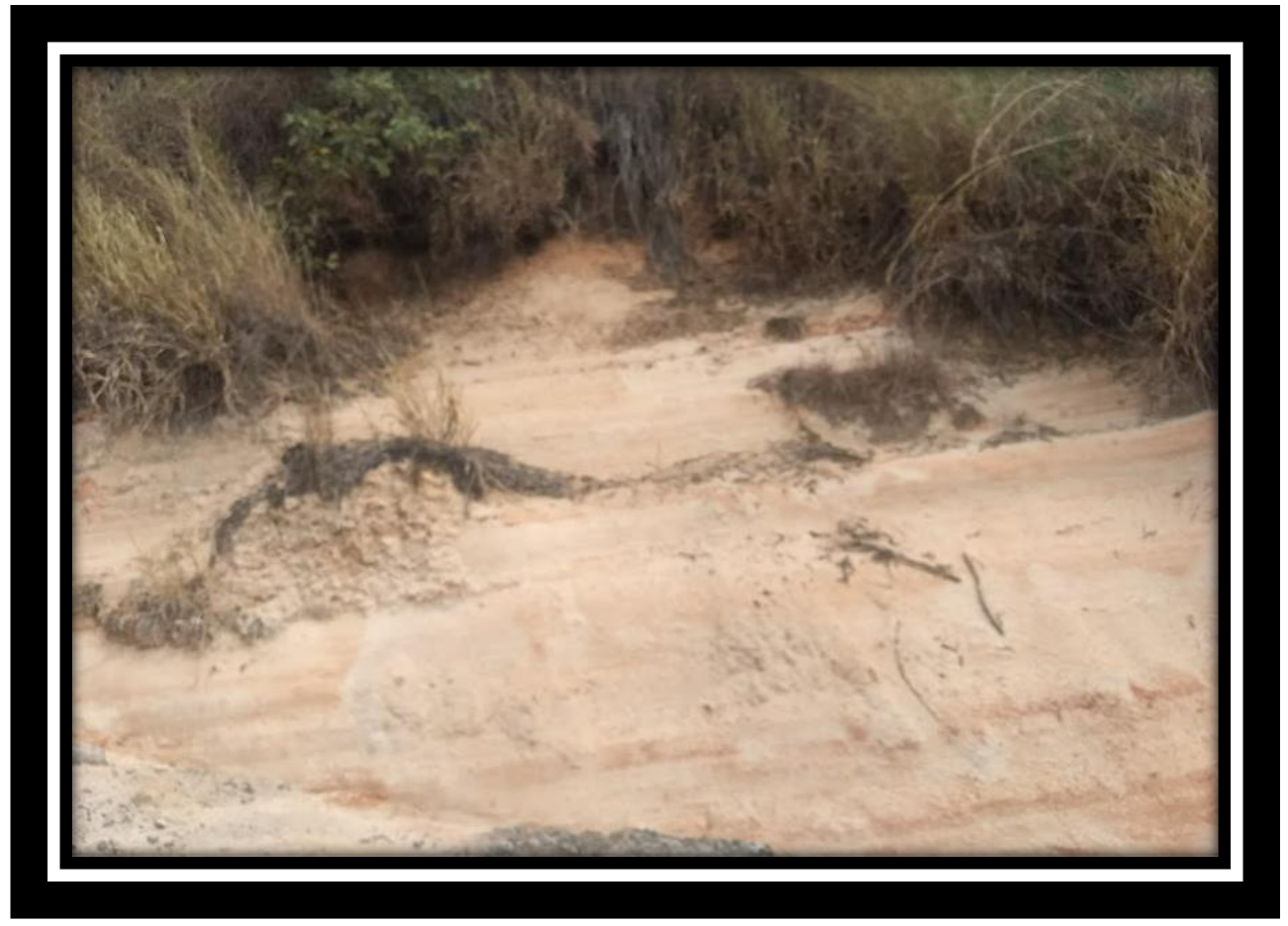

Figura 35: Solo arenoso em Torre de Pedra (SP). Fonte das fotos: Jéssica Vieira de Faria, 2018.

O foco do segundo trabalho de campo foi a observação dos usos do solo indicados no mapeamento. Nesse quesito, foram observadas divergências entre o mapeamento e a observação de campo. Essa diferença pode ser relacionada à escala de observação e às 
diferentes categorias de uso e ocupação do solo que podem apresentar arranjo e organização espacial semelhantes. Dentre os usos observados em campo, foram visitadas granjas, alambiques e chácaras de veraneio. Nas proximidades das chácaras de veraneio, cujo relevo era mais plano do que em outras áreas do município, houve a observação de fauna local, como aves (tucanos) e cobras. Também foi observado o intenso tráfego de veículos, tanto carros de passeio como ônibus rurais.

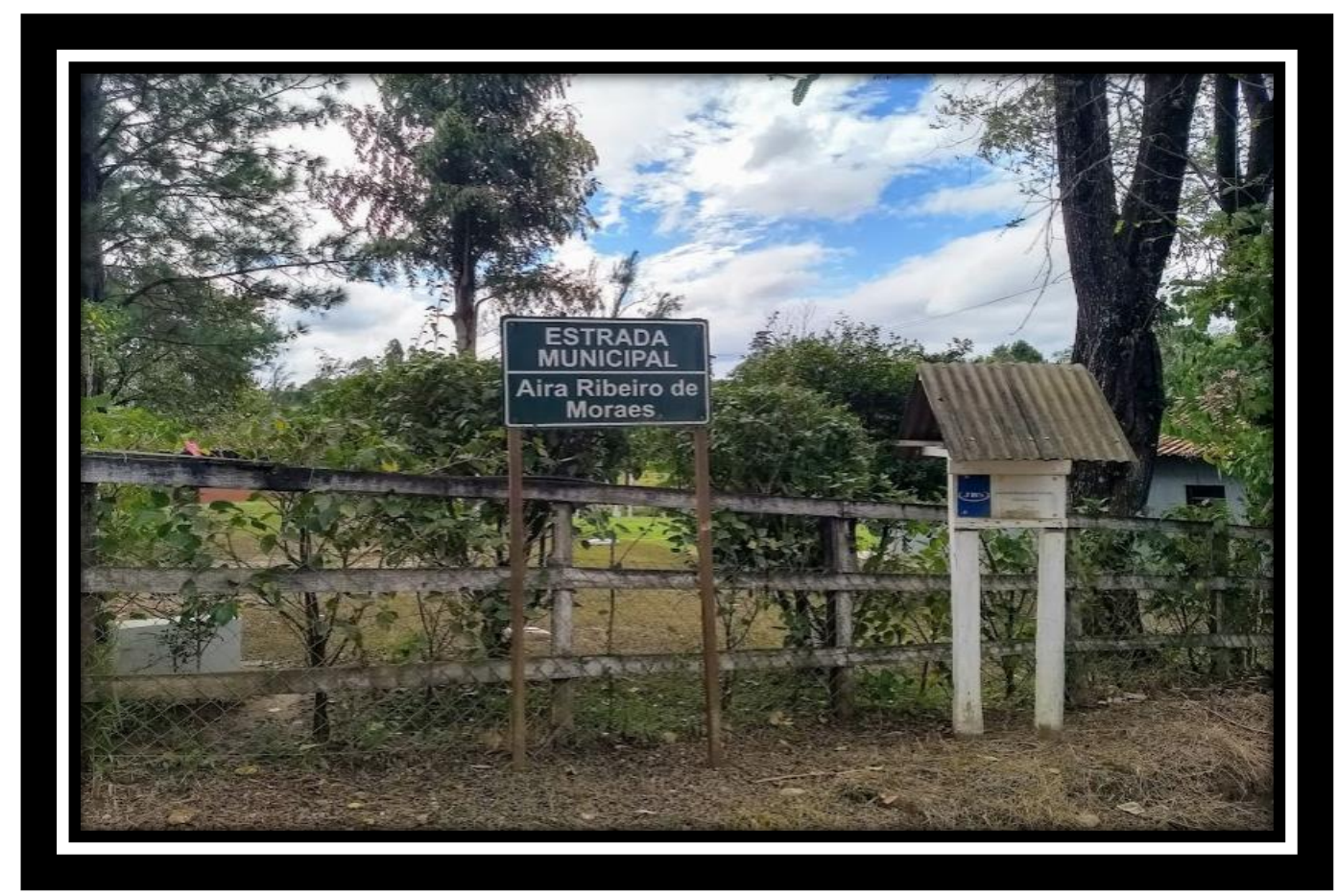

Figura 36: Entrada de granja associada à empresa JBS em Torre de Pedra (SP). Foto: Jéssica Vieira de Faria, 2018.

Durante esse trabalho de campo, foram observados os usos das áreas do município fora da abrangência da APA. Com o predomínio de pastagens, essa região apresenta diversas feições erosivas, mais acentuadas do que nas áreas visitadas no primeiro trabalho de campo. São ravinas e sulcos profundos, resultantes do pisoteio do gado (figuras 38 e 39). Além disso, há muitas propagandas de perfuração de poços artesianos, indicando que há exploração do Aquífero Guarani na região. 

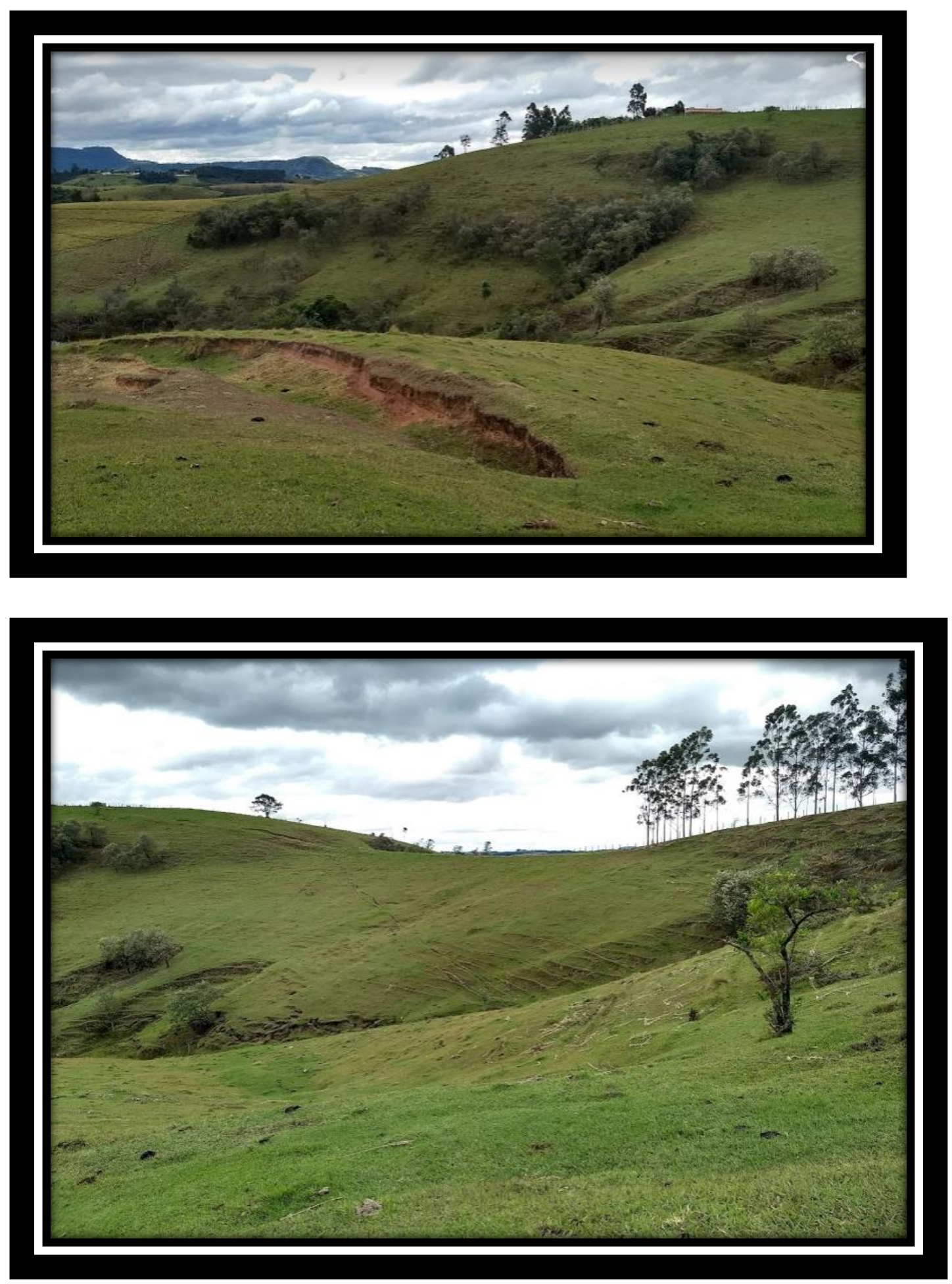

Figuras 37 e 38: Feições erosivas relacionadas ao pisoteio do gado em Torre de Pedra (SP). Foto: Jéssica Vieira de Faria, 2018.

A pecuária leiteira é tão presente no município que existe a Associação de Produtores Rurais de leite de Torre de Pedra (figura 39). 


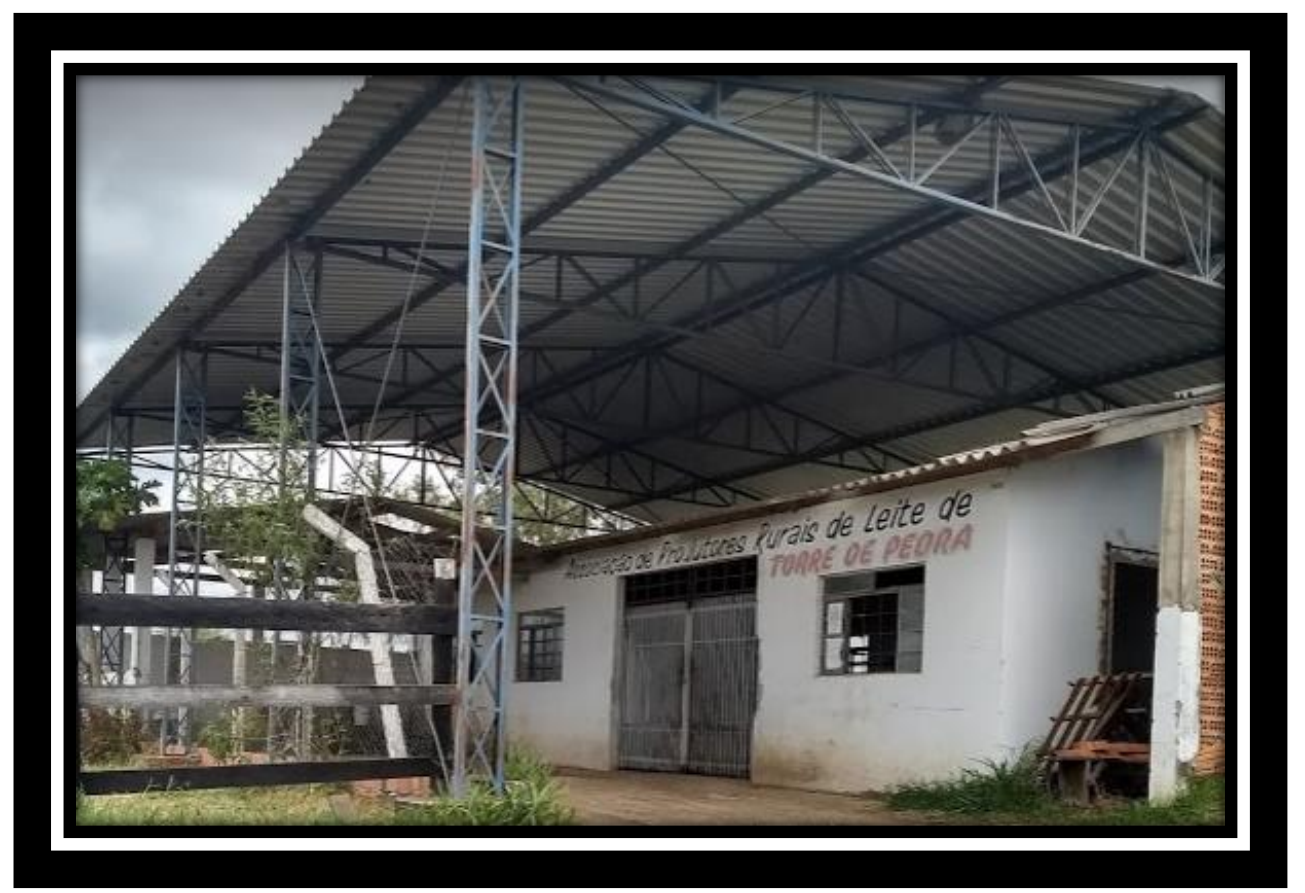

Figura 39: Sede da Associação de Produtores Rurais de leite de Torre de Pedra. Foto: Jéssica Vieira de Faria, 2018.

Também observou-se o grande número de empreendimentos de silvicultura, espalhados por todo o município. No mapeamento, apenas as áreas mais extensas foram observadas.

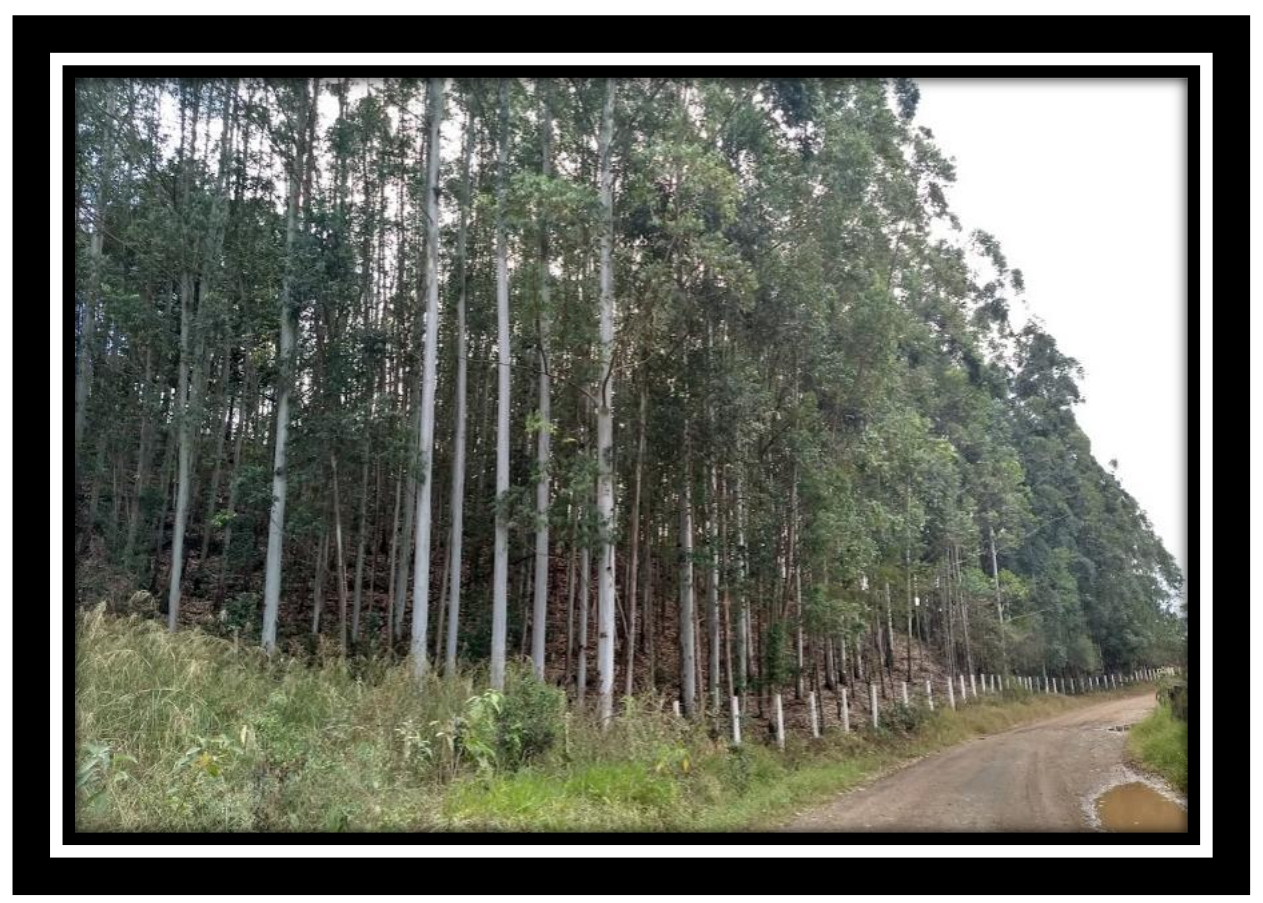

Figura 40: Silvicultura em Torre de Pedra (SP), fora da abrangência da APA. Foto: Jéssica Vieira de Faria, 2018. 
O empreendimento de mineração está localizado na área noroeste do município de Torre de Pedra, divisa com o município de Bofete. Durante o trabalho de campo, a mineração estava fechada. Contudo, em conversa com moradores locais e com um dos porteiros que mora na fazenda, soube-se que a mineração de areia, com mais de 20 anos de atividade, está em processo de desativação por problemas judiciais de disputas entre o herdeiros após o falecimento do antigo proprietário (Jorge Yunes). O imóvel onde está localizada a mineração (Fazenda São Jorge), sede da Yunes Mineração, possui uma área de mais de 1000 alqueires. Segundo o Departamento Nacional de Produção Mineral (DNPM, 2007), a Yunes Mineração é um empreendimento de mineração de areia de porte P3 (pequena, com uma produção de minério entre 50.000 e 100.000 ton/ano). A fazenda São Jorge também constitui um polo turístico, por ser um local com infraestrutura para eventos de médio porte, como piscinas, chalés e quadras poliesportivas. Segundo os relatos, já foi iniciado o processo de desmonte do maquinário de extração de areia, contudo, não houve relatos sobre planos futuros para recuperação da área. É necessário avaliar o impacto ambiental que a atividade mineradora deixou e quais são os planos de manejo para recuperação da área da mineradora, considerando a inserção dessa área dentro da APA. Nos documentos analisados (plano de manejo), a atividade mineradora é citada, contudo não são aprofundados os possíveis impactos da mineração. 


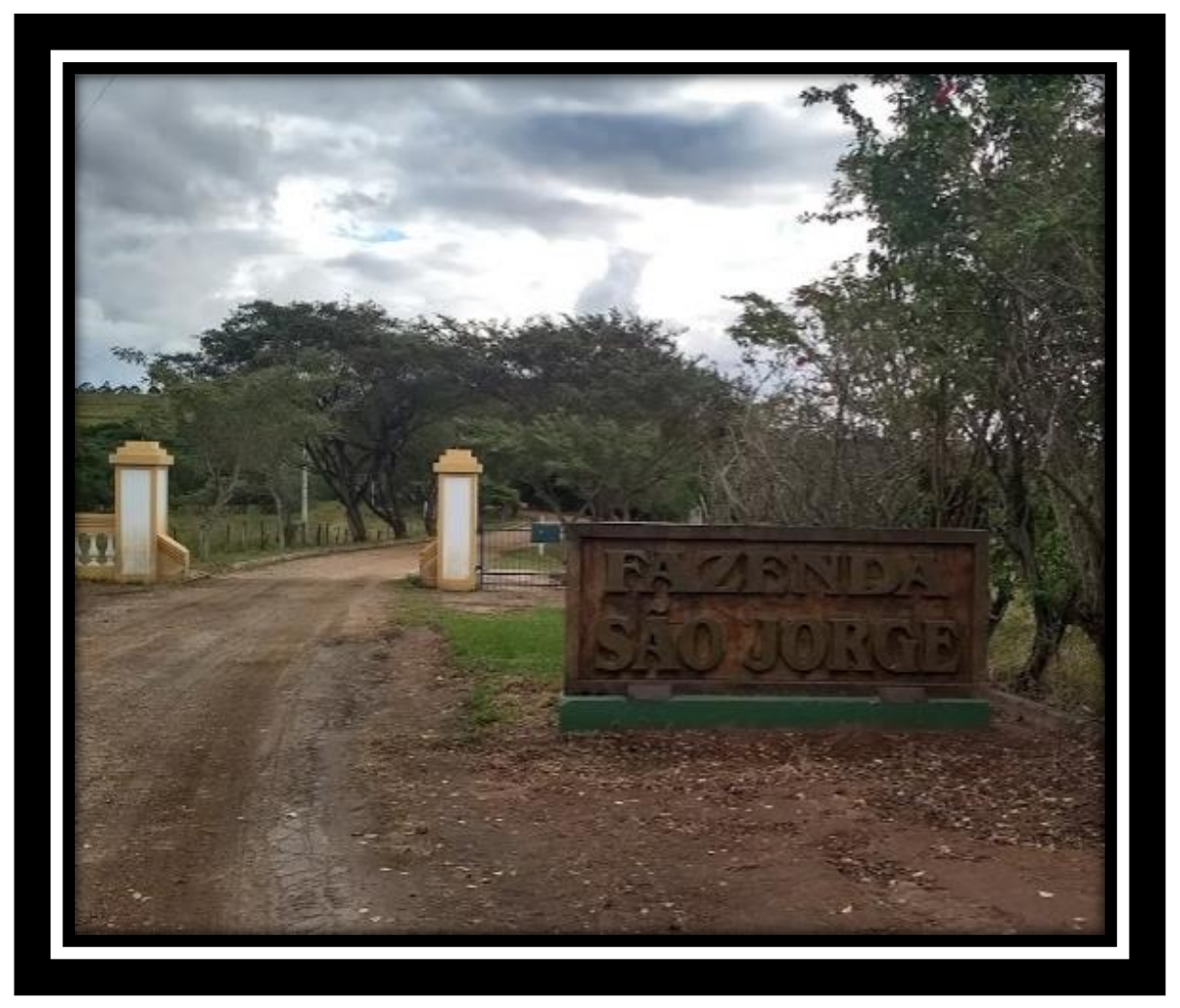

Figura 41: Entrada da Fazenda São Jorge, no quilômetro 172 da Rodovia Castelo Branco. Foto: Jéssica Vieira de Faria, 2018.

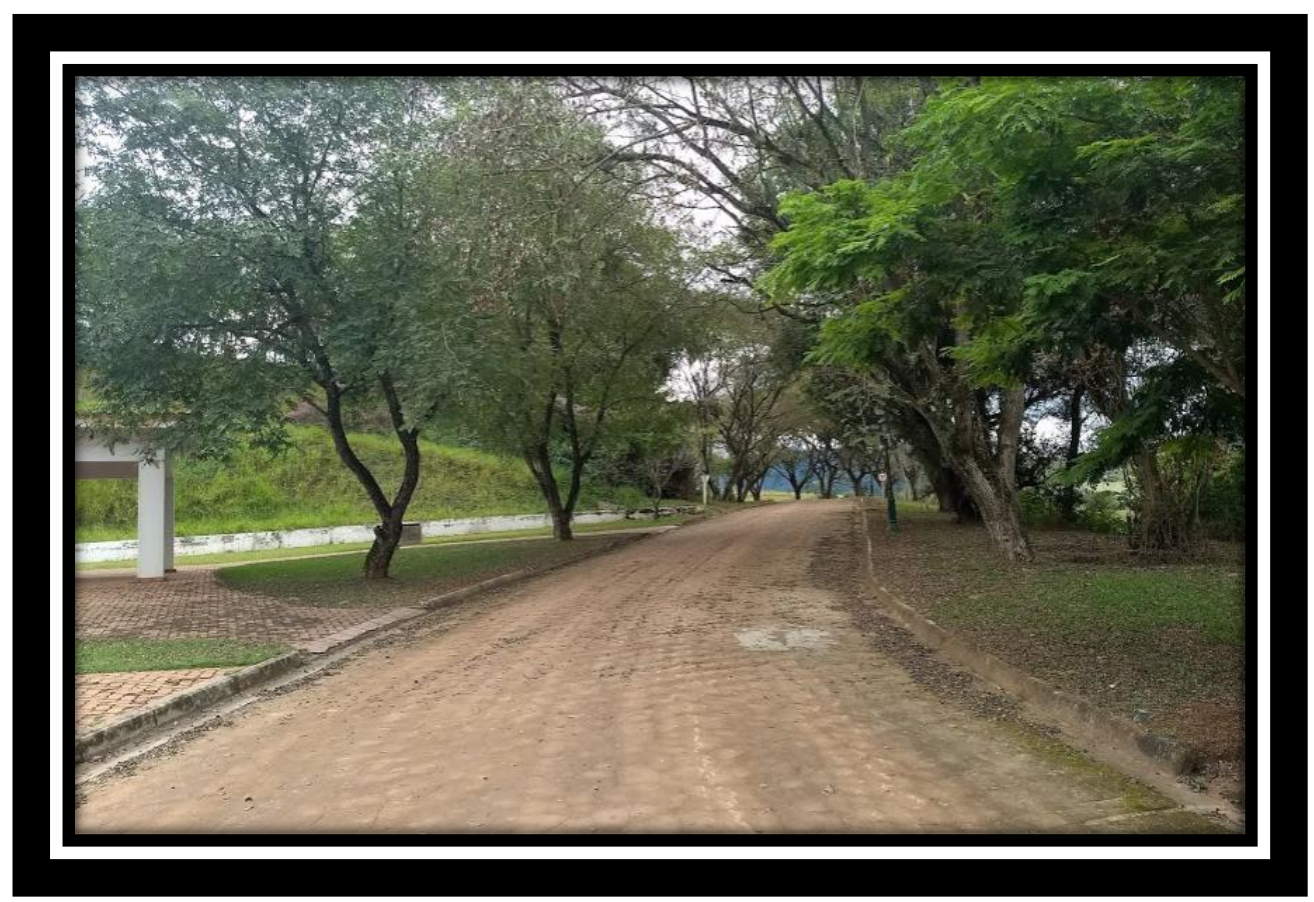

Figura 42: Acesso à mineração de areia na Fazenda São Jorge. Foto: Jéssica Vieira de Faria, 2018. 


\section{C MAPEAMENTO SÍNTESE}

\section{C.1 Critérios para delimitação das unidades de paisagem}

As unidades de paisagem foram delimitadas a partir de critérios levantados na literatura, especialmente: Delpoux, (1974); Távora e Turetta (2016) e Mateo-Rodriguez et al. (2007).

Baseado em Delpoux, 1974, que afirma que o suporte e a cobertura são os componentes fundamentais da paisagem, as unidades de paisagem seguiram os seguintes níveis de delimitação:

Suporte: níveis 1 e 2

Nível 1) Domínios geomorfológicos (geomorfologia e geologia)

Nível 2) Padrões de forma de relevo (formas de relevo e solos)

Cobertura: nível 3

Nível 3) Unidades de paisagem (uso da terra/cobertura vegetal)

Uma proposta semelhante de modelo de delimitação de unidades de paisagens também está presente em Távora e Turetta (2016) e Mateo-Rodriguez et al. (2007).

As variáveis do trabalho estão relacionadas aos critérios selecionados para a delimitação das unidades de paisagem:

- Variável teórica: unidades de paisagem definida baseada em sua função e dinâmica

- Variáveis operacionais: uso do solo e cobertura vegetal, forma de relevo, pedologia, litologia.

A pesquisa levou em conta fatores abióticos e fatores associados ao uso do solo em escala de maior detalhe. Assim, a hierarquização proposta leva em consideração esses fatores em nível de maior detalhamento.

Partindo dessa delimitação foi possível a identificação das potencialidades e restrições de uso e ocupação da terra presentes na área de estudo e a consequente proposta de ordenamento territorial com ênfase à preservação do morro-testemunho de Torre de Pedra e seu entorno.

Os mapas necessários para a confecção do mapa de Unidades de Paisagem estão no quadro a seguir. A escala trabalhada foi 1:60.000, que abrange todo o município de Torre de Pedra. Os mapeamentos dos diferentes critérios de mapeamento foram analisados separadamente, culminando com a análise conjunta que foi utilizada para a 
confecção do mapa de unidades de paisagem. O resultado dessa análise está descrito a seguir.

\section{C.1a Mapas de suporte: geologia}

O mapa geológico do município de Torre de Pedra apresentou dois tipos de formação: Formação Piramboia e Formação Teresina (mapa 5).

Segundo o CPRM, a P3t - Formação Teresina pertence ao Grupo Passa Dois e "é constituída por argilitos, siltitos e arenitos muito finos e finos, cinza escuros a esverdeados, com geometria tabular ou lenticular muito estendida" (CPRM, 2018, p. 163). Já a P3T1p - Formação Pirambóia RCL/AM é constituída por “arenitos médios e

finos com cores esbranquiçadas, avermelhadas e alaranjadas [...] É fonte de areias quartzosas para uso industrial e suas camadas de arenitos são parte constituinte do Aqüífero Guarani.” (CPRM, 2018, p. 166) 


\section{Torre de Pedra (SP) Mapa geológico}

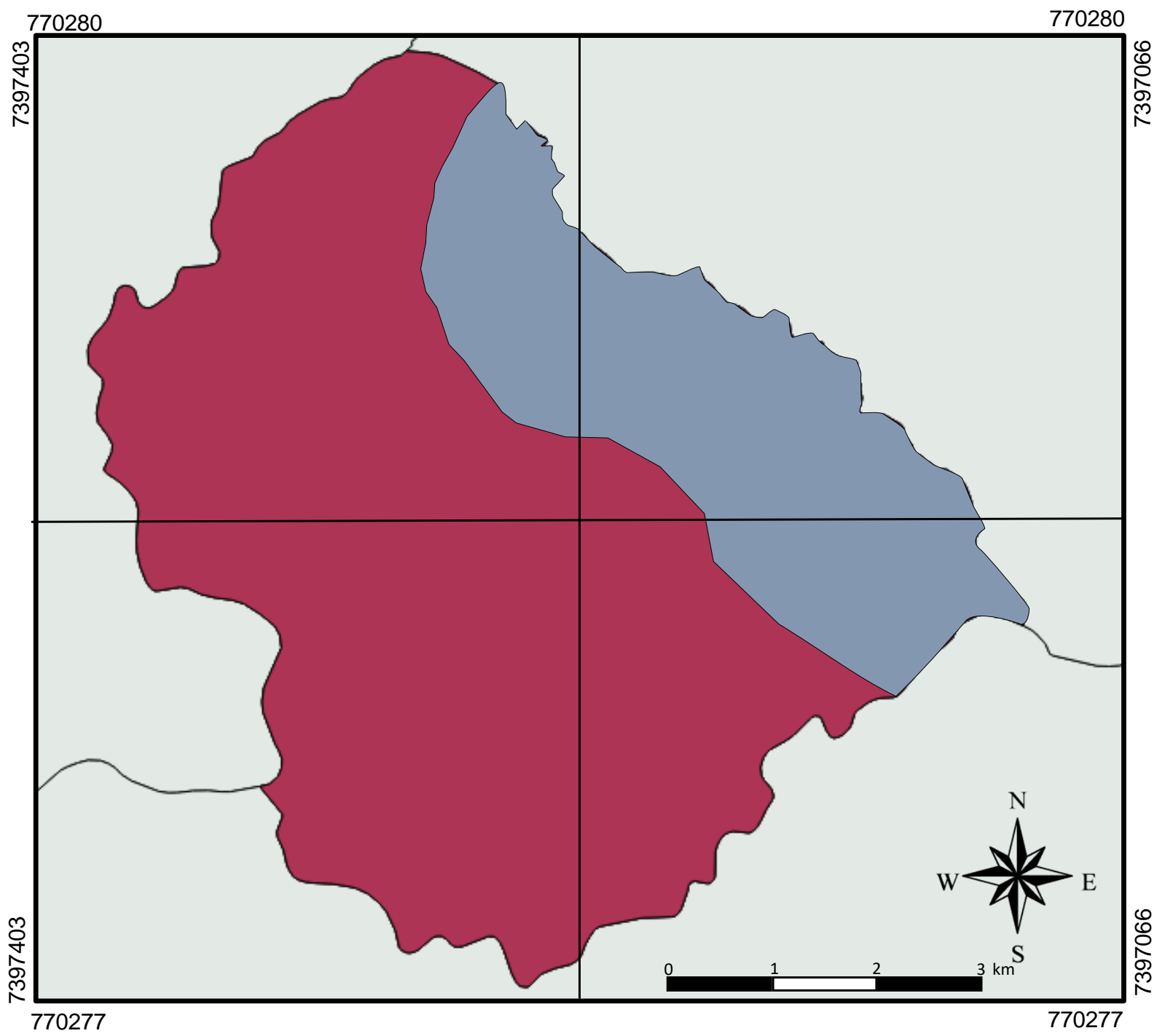

\section{Legenda \\ P3t - Formação Teresina \\ P3T1p - Formação Piramboia}

Escala: 1:60.000

Fonte: CPRM, 2018; SÃO PAULO, 2006.

Projeção: Universal Transversa de Mercator
Datum horizontal: SIRGAS 2000 UTM Zone $23 \mathrm{~S}$ Data: março de 2018.

Elaborado através do software QGis por Faria, J.V. 


\section{C.1b Mapas de suporte: geomorfologia}

Ross e Moroz, 1997, classificam essa região como Depressão Periférica e Zona do Médio Tietê (mapa 6), sendo caracterizada por colinas de topos convexos, morrotestemunhos e formação residuais da borda da cuesta. Essas características foram comprovadas durante os trabalhos de campo, assim como a elevação de morros que caracteriza a divisa entre os municípios de Torre de Pedra e Guareí, denominada pelos moradores locais de Espigão da Areia Branca (figura 43).

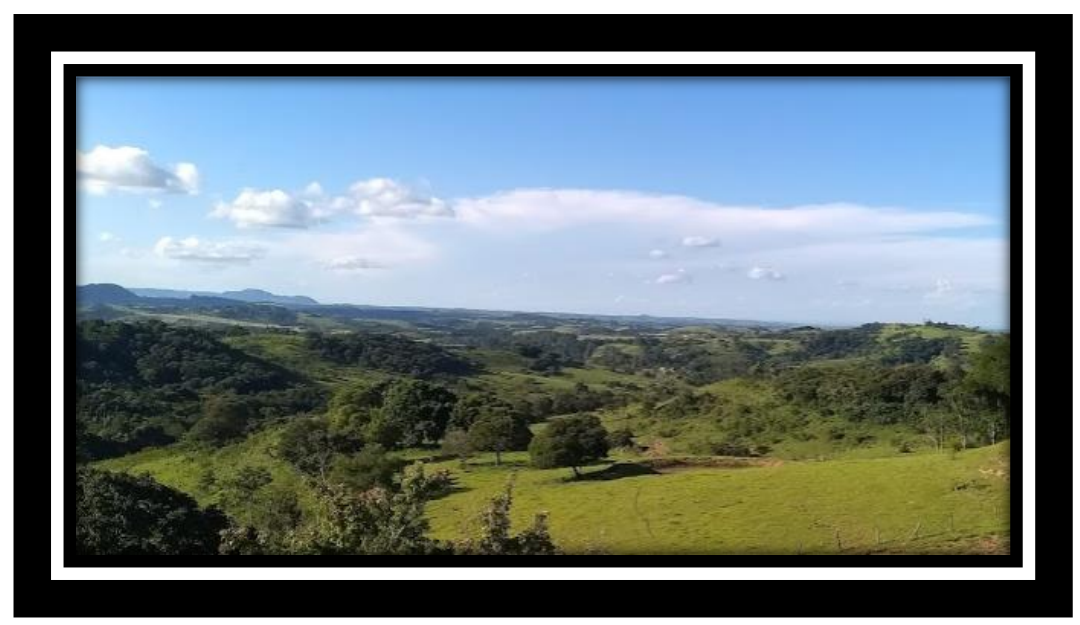

Figura 43: Morros convexos do Espigão da Areia Branca. Foto: Jéssica Vieira de Faria, 2018.

O Espigão da Areia Branca apresenta colinas de topos convexos, no sudeste do município de Torre de Pedra, divisa com o município de Guareí. Ao observar o perfil topográfico do entorno do município, é perceptível a elevação no trecho sudeste, indicando o espigão da areia branca, divisa com o município de Guareí, conforme indica o perfil a seguir.

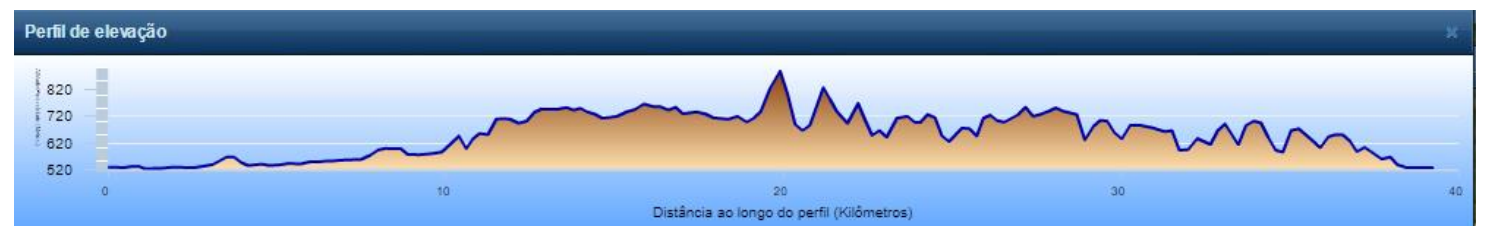

Figura 44: Perfil de elevação da divisa entre Torre de Pedra e Guareí (SP). Fonte: CPRM, 2018.

O espigão da Areia Branca marca o interflúvio entre diferentes bacias hidrográficas. Isso é comprovado pelas UGHRI (unidades hidrográficas de gerenciamento de recursos hídricos do Estado de São Paulo): enquanto o município de Torre de Pedra faz parte da UGHRI 10 do estado de São Paulo (Tietê/Sorocaba), o município de Guareí pertence à UGHRI 14, Alto Paranapanema. 


\section{Torre de Pedra (SP) Mapa geomorfológico}

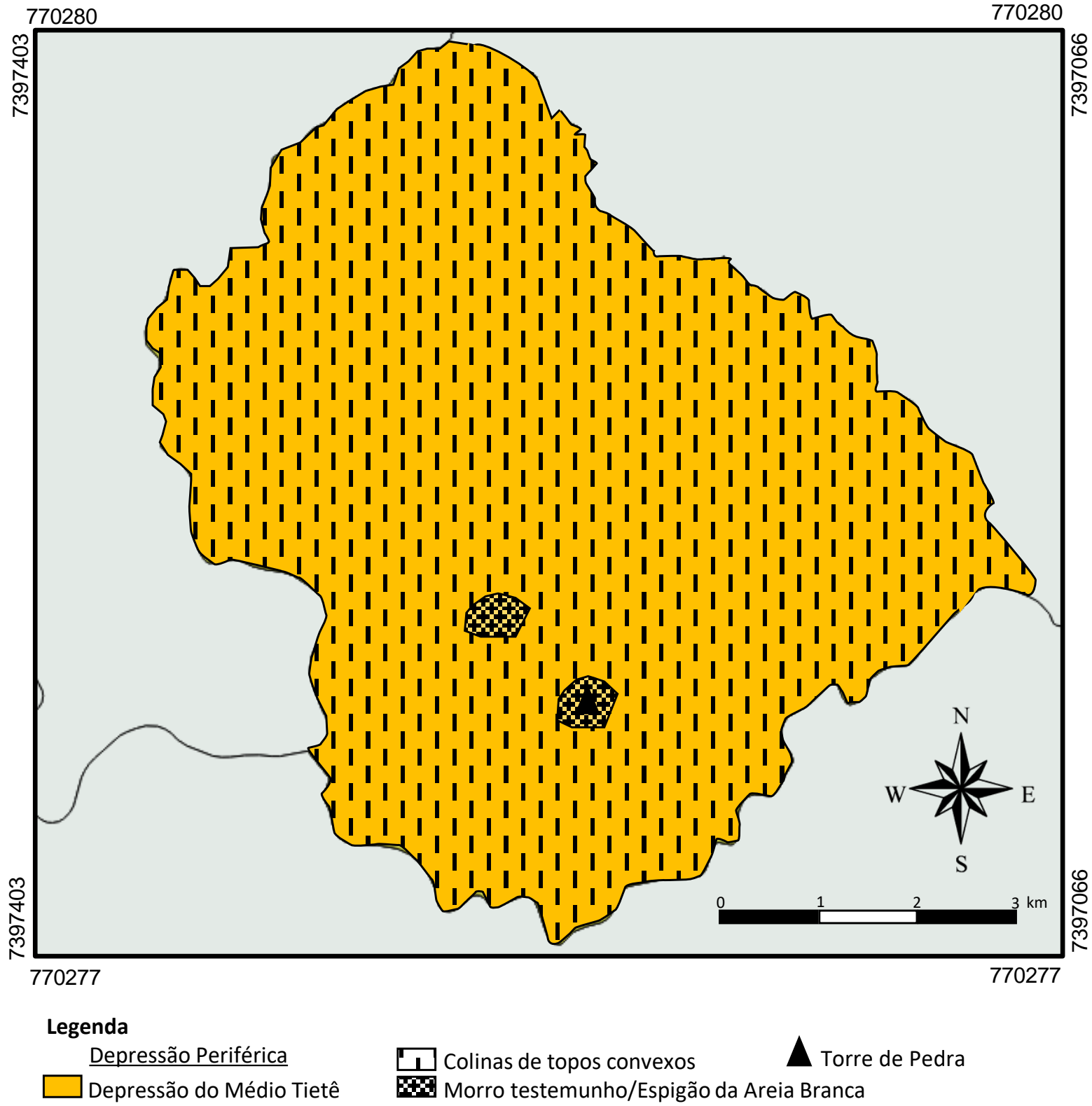

Escala: 1:60.000

Fonte: ROSS\&MOROZ, 2011.

Projeção: Universal Transversa de Mercator
Datum horizontal: SIRGAS 2000 UTM Zone 23 S

Data: março de 2018.

Elaborado através do software QGis por Faria, J.V. 


\section{Torre de Pedra (SP) Dissecação do relevo}

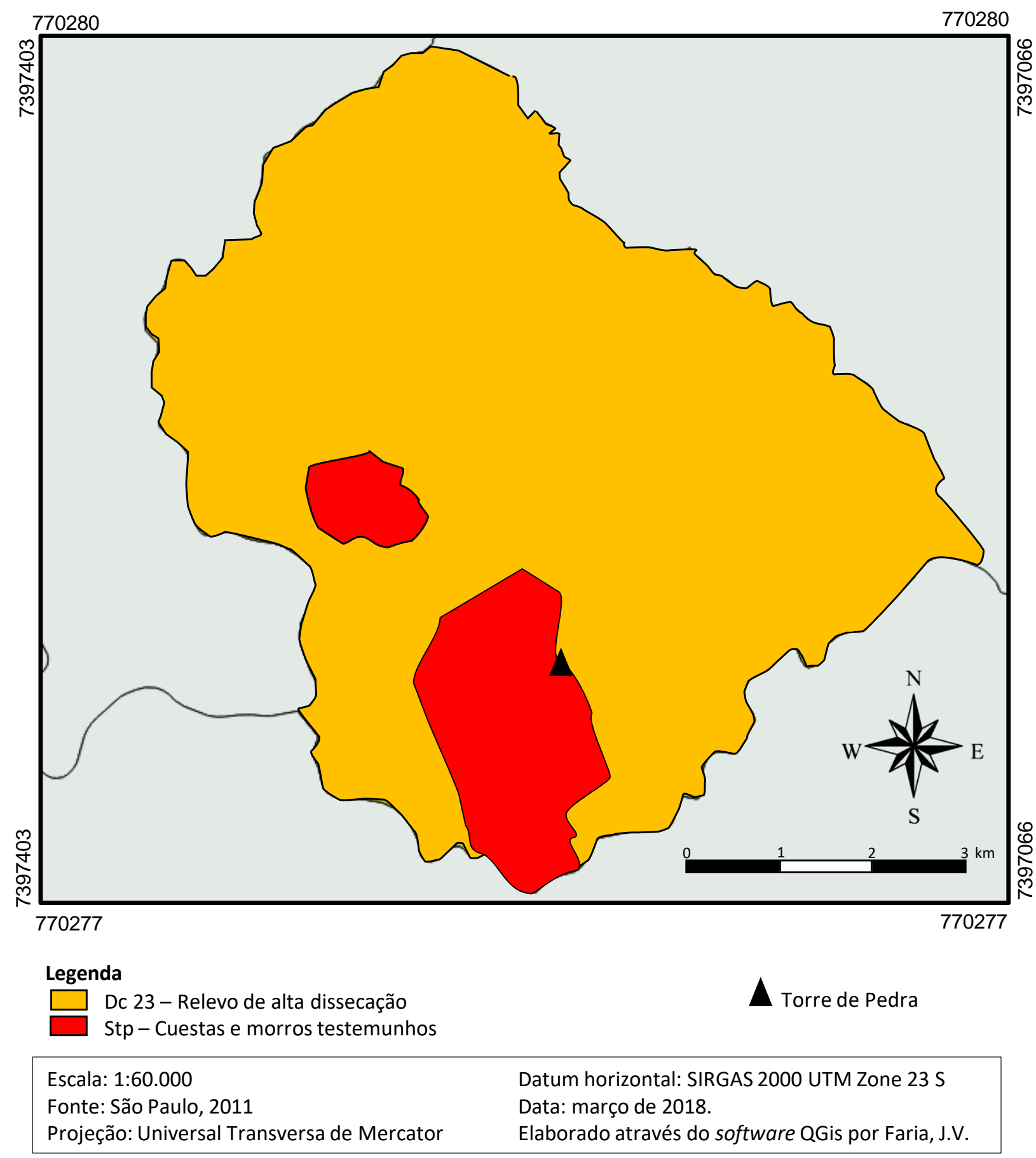




\section{C.1c Mapas de suporte: pedologia}

Há dois tipos de solos na área de estudo:

- Argissolo vermelho amarelo: solos avermelhados devido aos óxidos de ferro, cuja fertilidade varia de acordo com o material de origem: na área de estudo, esses solos são considerados pouco férteis;

- Nitossolo litólico: solos rasos, relacionados a relevos declivosos, e, assim como os argissolos, podem apresentar alta ou baixa fertilidade. (EMBRAPA, 2018)

Esses tipos de solo foram visualizados durante trabalhos de campo (figuras $46 \mathrm{e}$ 47), nas áreas indicadas no mapeamento (mapa 8).
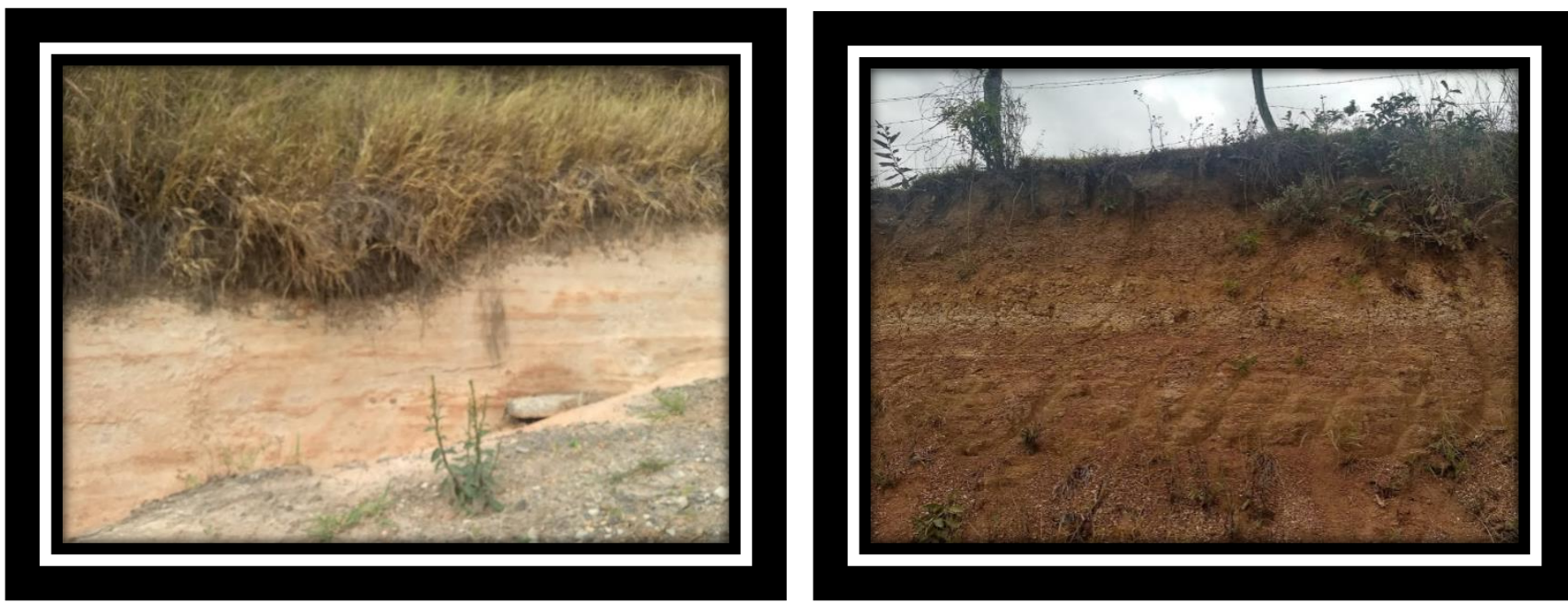

Figuras 45 e 46: Diferentes tipos de solo observados durante os trabalhos de campo: solo mais raso e menos desenvolvido à esquerda; solo mais profundo e com mais horizontes à direita. Foto: Jéssica Vieira de Faria, 2018. 


\section{Torre de Pedra (SP) Mapa pedológico}

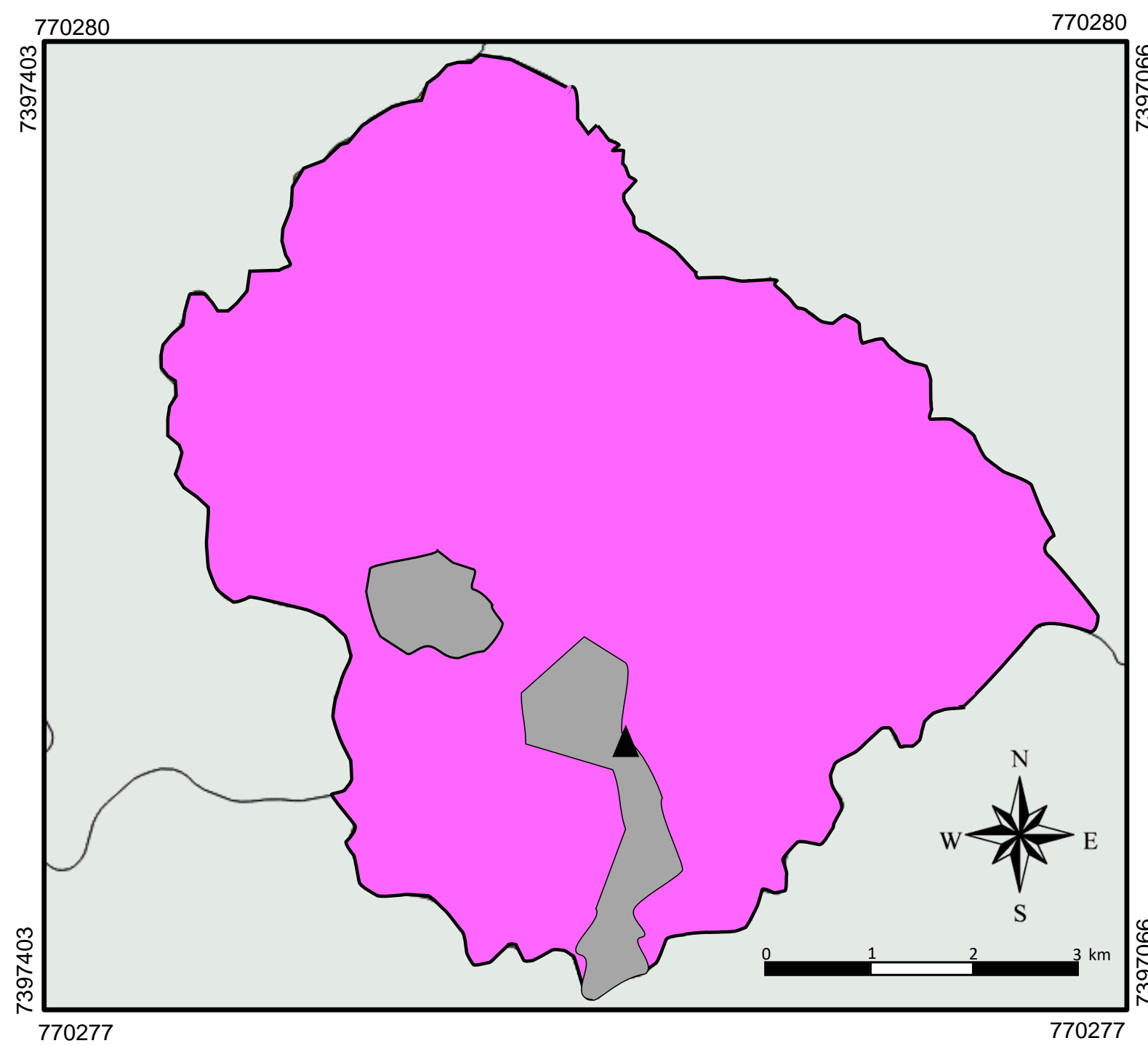

Legenda

PVA 33/PVA 14 - Argissolo vermelho-amarelo

RL 13 - Neossolo litólico

Escala: 1:60.000

Fonte: ROSSI, 2017; SÃO PAULO, 2011

Projeção: Universal Transversa de Mercator
Datum horizontal: SIRGAS 2000 UTM Zone 23 S Data: março de 2018.

Elaborado através do software QGis por Faria, J.V. 


\section{C.1d Cobertura: Mapa de uso do solo e abrangência da APA}

Nos mapas de cobertura, além do mapa de uso do solo (mapa 9), também foi confeccionado o mapa sobre a abrangência da APA em relação ao município de Torre de Pedra (mapa 10).

O mapa de uso do solo foi realizado a partir das imagens de satélite (figura 48) e apresentou predominância de pastagens com vegetação esparsa. As matas ciliares ao redor de córregos também são marcantes na paisagem, com presença de enclaves de silvicultura e uma grande mineração de areia no noroeste do município, próximo à divisa com Bofete. Além disso, em trabalhos de campo, foram observadas grandes áreas não mapeadas de chácara de veraneio e granjas.

Em relação à abrangência da APA, é notável que a área de proteção ambiental abrange cerca de $50 \%$ do município. Contudo, a dinâmica que ocorre nas outras áreas municipais também influenciam a dinâmica hídrica do município, o que poderia justificar uma atualização da divisa da APA de modo a abranger todo o município.

O uso do solo no entorno do município é heterogêneo: o limite com o município de Guareí, na parte sul, apresenta áreas preservadas. Por outro lados, na divisa com os municípios de Porangaba e Bofete, há mais áreas desmatadas dedicadas à pastagem.

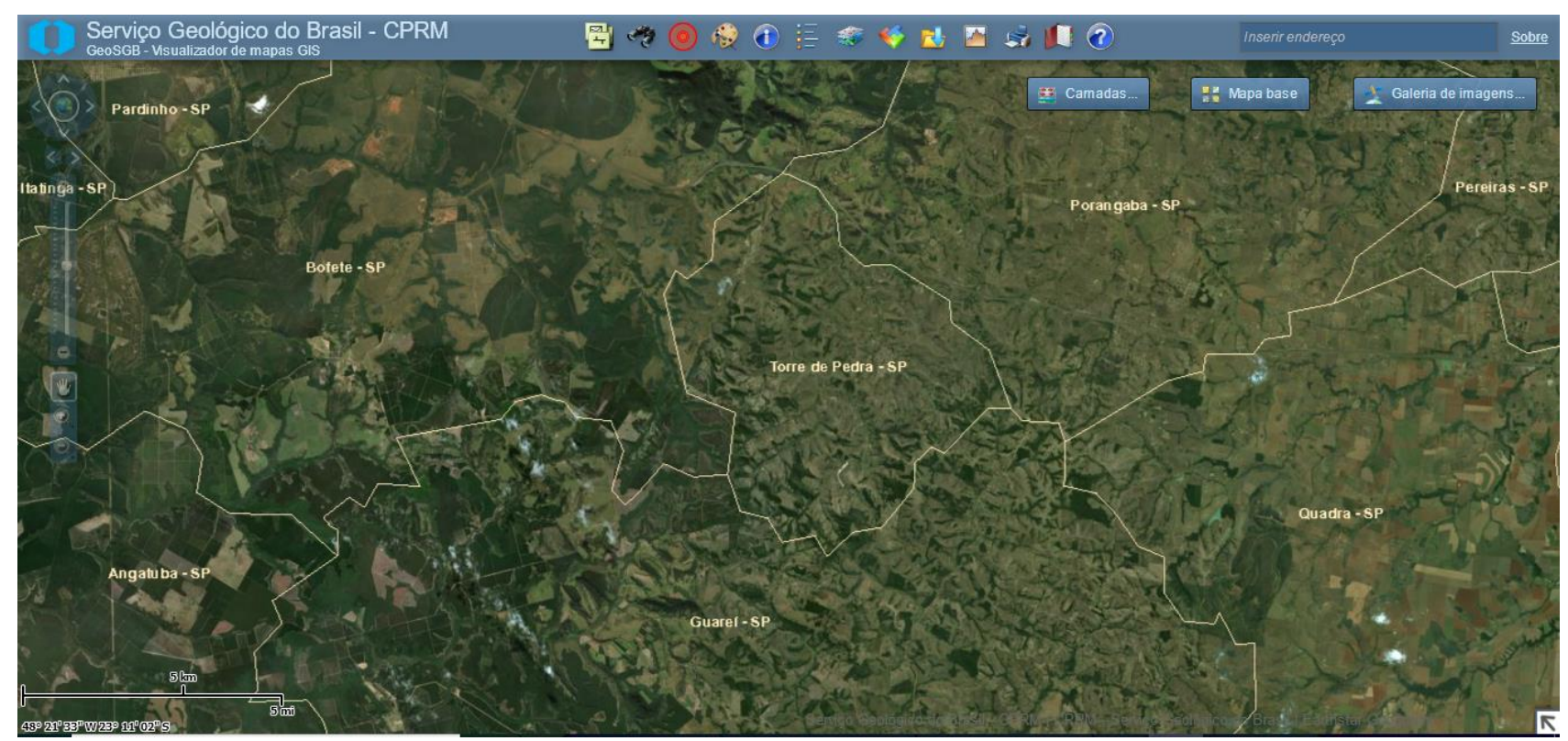

Figura 47: Imagem de satélite Google Earth/CPRM utilizada para o mapeamento de uso do solo. Fonte: CPRM, 2018. 


\section{Torre de Pedra (SP)}

Mapa de uso do solo e cobertura vegetal

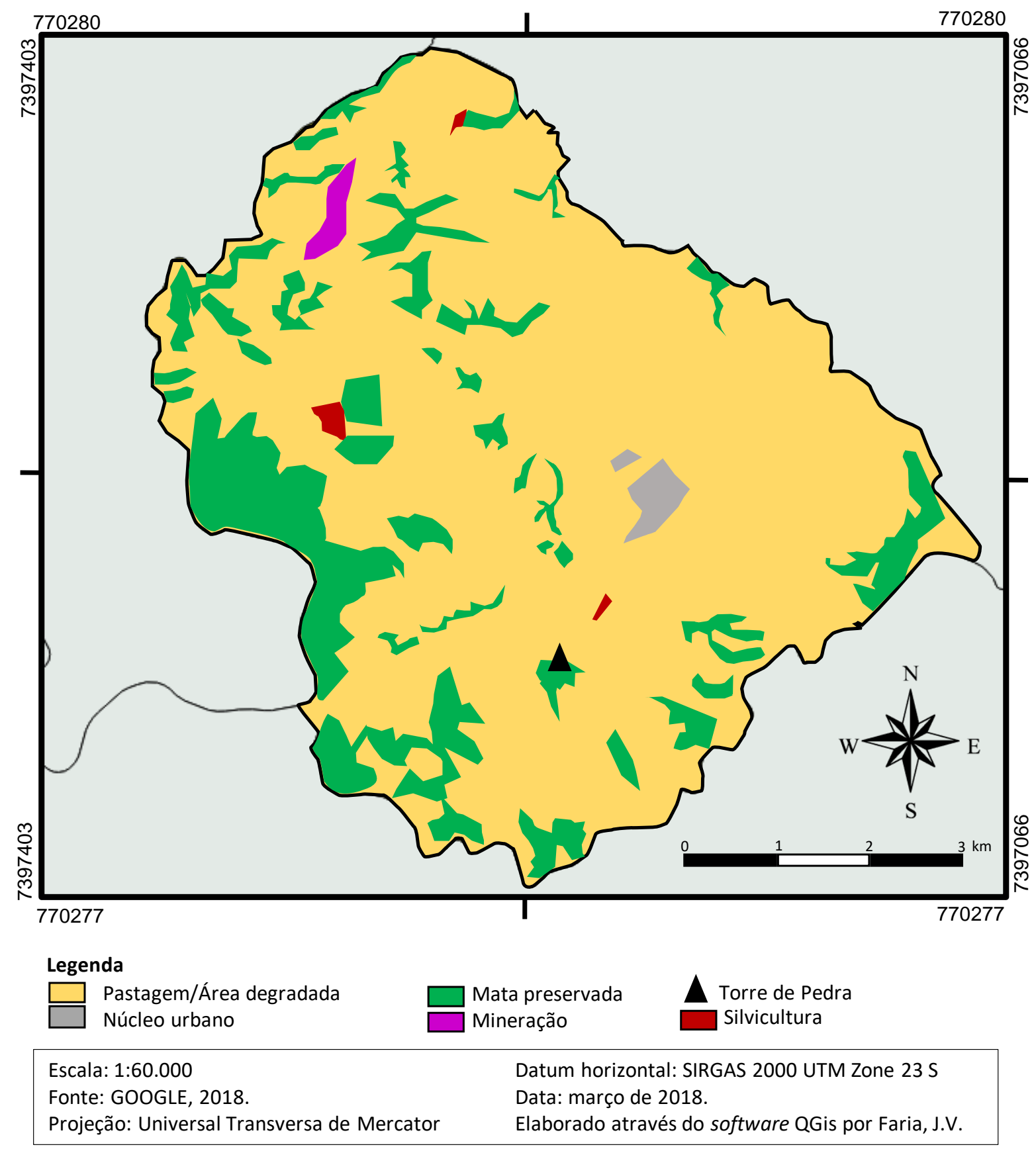




\section{Torre de Pedra (SP) Área do município inserida na APA}

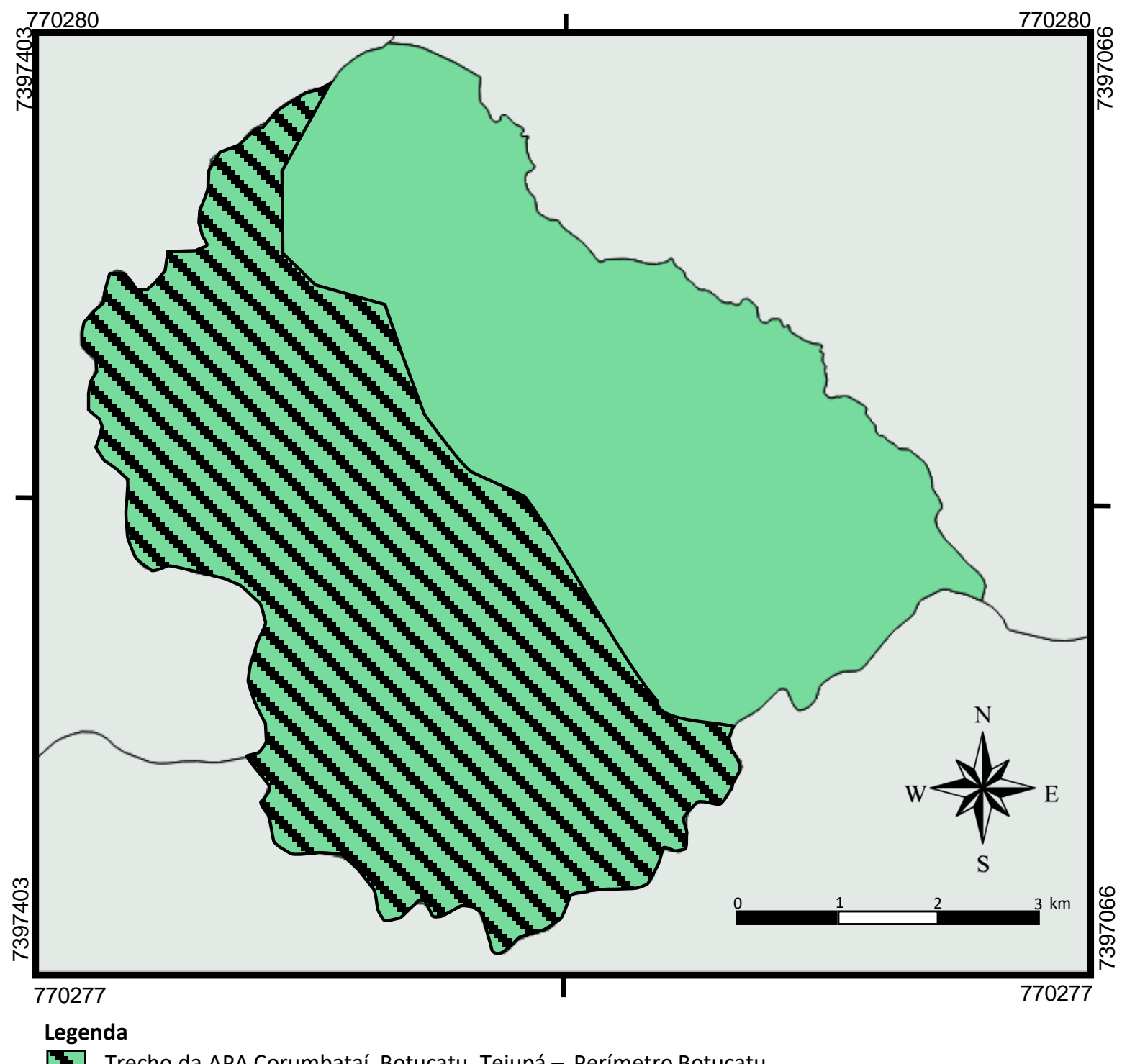

Trecho da APA Corumbataí, Botucatu, Tejupá - Perímetro Botucatu

Escala: 1:60.000

Fonte: SÃO PAULO, 2008.

Projeção: Universal Transversa de Mercator
Datum horizontal: SIRGAS 2000 UTM Zone 23 S Data: março de 2018.

Elaborado através do software QGis por Faria, J.V. 


\section{C.2 Mapeamento síntese}

Como produto final, a análise entre compartimentação geomorfológica, unidades geoambientais e o uso do solo da área de estudo resultou na confecção do mapa Unidades de Paisagem da área de estudo.

\section{Mapa de Unidades de Paisagem}

A partir da análise integrada dos mapas mencionados no tópico anterior, o mapa de Unidades de Paisagem foi estabelecido, com quatro unidades: 


\section{Torre de Pedra (SP)}

Unidades de paisagem

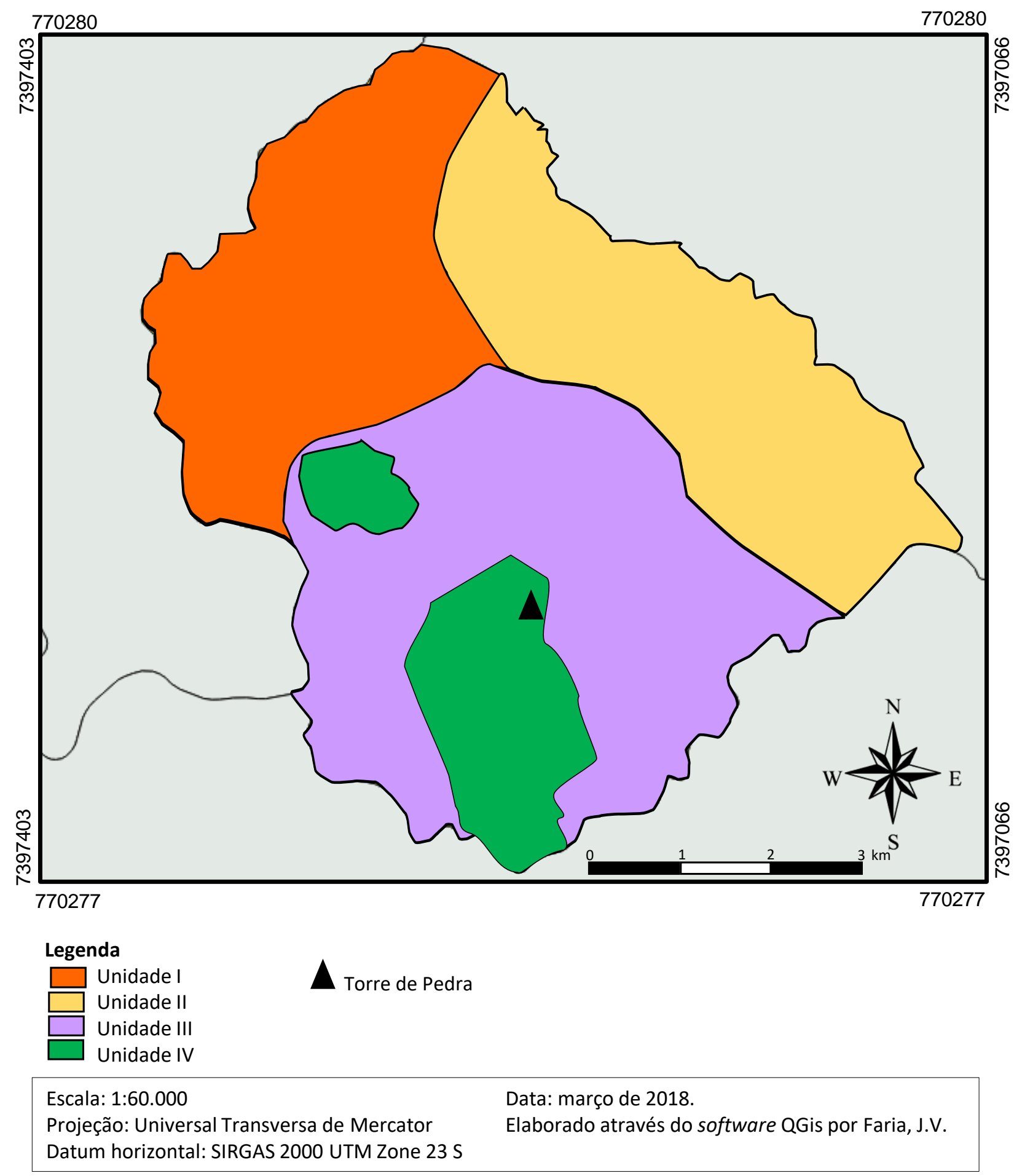


Quadro 6: Quadro com as características das UPs delimitadas.

Organização: Jéssica Vieira de Faria, 2018.

\begin{tabular}{|c|c|c|c|c|c|c|}
\hline & $\begin{array}{l}\text { Geomorfologia } \\
\text { (macroestrutura) }\end{array}$ & Geologia & $\begin{array}{l}\text { Formas de } \\
\text { relevo }\end{array}$ & Pedologia & $\begin{array}{l}\text { Uso do solo } \\
\text { e cobertura } \\
\text { vegetal }\end{array}$ & $\begin{array}{l}\text { Está } \\
\text { inserido na } \\
\text { região de } \\
\text { APA? }\end{array}$ \\
\hline $\begin{array}{l}\text { Unidade } \\
\text { I }\end{array}$ & $\begin{array}{l}\text { Depressão } \\
\text { Periférica - } \\
\text { Depressão do } \\
\text { Médio Tietê }\end{array}$ & $\begin{array}{l}\text { Formação } \\
\text { Piramboia }\end{array}$ & $\begin{array}{l}\text { Colinas de } \\
\text { topos } \\
\text { convexos e } \\
\text { alta } \\
\text { dissecação }\end{array}$ & $\begin{array}{l}\text { Argissolo } \\
\text { vermelho- } \\
\text { amarelo }\end{array}$ & $\begin{array}{l}\text { Pastagem; } \\
\text { mineração } \\
\text { de areia; } \\
\text { mata } \\
\text { primária e } \\
\text { secundária; } \\
\text { silvicultura }\end{array}$ & Sim \\
\hline $\begin{array}{l}\text { Unidade } \\
\text { II }\end{array}$ & $\begin{array}{l}\text { Depressão } \\
\text { Periférica - } \\
\text { Depressão do } \\
\text { Médio Tietê }\end{array}$ & $\begin{array}{l}\text { Formação } \\
\text { Teresina }\end{array}$ & $\begin{array}{l}\text { Colinas de } \\
\text { topos } \\
\text { convexos e } \\
\text { alta } \\
\text { dissecação }\end{array}$ & $\begin{array}{l}\text { Argissolo } \\
\text { vermelho- } \\
\text { amarelo }\end{array}$ & $\begin{array}{l}\text { Pastagem e } \\
\text { mata } \\
\text { primária e } \\
\text { secundária. }\end{array}$ & Não \\
\hline $\begin{array}{l}\text { Unidade } \\
\text { III }\end{array}$ & $\begin{array}{l}\text { Depressão } \\
\text { Periférica - } \\
\text { Depressão do } \\
\text { Médio Tietê }\end{array}$ & $\begin{array}{l}\text { Formação } \\
\text { Piramboia }\end{array}$ & $\begin{array}{l}\text { Colinas de } \\
\text { topos } \\
\text { convexos e } \\
\text { alta } \\
\text { dissecação }\end{array}$ & $\begin{array}{l}\text { Argissolo } \\
\text { vermelho- } \\
\text { amarelo }\end{array}$ & $\begin{array}{l}\text { Pastagem; } \\
\text { mata } \\
\text { primária e } \\
\text { secundária; } \\
\text { silvicultura; } \\
\text { área urbana. }\end{array}$ & Sim \\
\hline $\begin{array}{l}\text { Unidade } \\
\text { IV }\end{array}$ & $\begin{array}{l}\text { Depressão } \\
\text { Periférica - } \\
\text { Depressão do } \\
\text { Médio Tietê }\end{array}$ & $\begin{array}{l}\text { Formação } \\
\text { Piramboia }\end{array}$ & $\begin{array}{l}\text { Colinas de } \\
\text { topos } \\
\text { convexos e } \\
\text { alta } \\
\text { dissecação; } \\
\text { morro- } \\
\text { testemunhos } \\
\text { e cuestas }\end{array}$ & $\begin{array}{l}\text { Neossolo } \\
\text { litólico }\end{array}$ & $\begin{array}{l}\text { Mata } \\
\text { primária e } \\
\text { secundária; } \\
\text { afloramento } \\
\text { rochoso; } \\
\text { pastagem }\end{array}$ & Sim \\
\hline
\end{tabular}




\section{Unidade I}

Esta unidade é caracterizada pela formação geológica Piramboia, com forma de relevo predominante de colinas de topos convexos e alta dissecação do relevo. Apresente solo do tipo argissolo vermelho-amarelo e uso do solo diverso, com a predominância de pastagens e mata primária e secundária, porém também apresenta empreendimentos como mineração de areia e silvicultura. Está inserida dentro da área da APA.

A avaliação dos mapas de uso do solo e declividade, além das observações feitas durante os trabalhos de campo, constatou que a mineração é a atividade que mais apresenta riscos para o equilíbrio geoambiental da unidade de paisagem. Assim, para que a mineração continue suas atividades nessa área, adaptações são necessárias para diminuir o impacto ambiental negativo, como aterros e escavações, e fins mais seguros para os resíduos da mineração, estudo dos impactos do despejo de resíduos nos córregos locais, mitigação do impacto sonoro. Contudo, conforme trabalhos de campo, esse empreendimento de mineração está sendo encerrado. Portanto, é importante avaliar quais são os planos de recuperação da área de mineração.

\section{Unidade II}

Única unidade constituída pela formação Teresina, a Unidade II também tem como forma de relevo predominante as colinas de topos convexos e alta dissecação do relevo e apresenta solo do tipo argissolo vermelho-amarelo. Contudo, essa unidade não está dentro da área de APA e o uso de solo é dominado por pastagens, com menor quantidade de mata primária e secundária.

As pastagens dessa unidade de paisagem não apresentavam feições erosivas do tipo pisoteio, e as ondulações do relevo eram menos declivosas do que as outras unidades de paisagem.

\section{Unidade III}

Unidade que também apresenta formação Piramboia, relevo com colinas de topos convexos e alta dissecação do relevo e solo do tipo argissolo vermelho-amarelo. A unidade está inserida dentro da APA e tem como principais usos do solo: pastagem; área urbana; silvicultura e mata primária/secundária.

Como tem um uso do solo muito diverso, essa unidade de paisagem apresenta diferentes tipos de riscos. Na área urbana, constatou-se o despejo de esgoto diretamente sobre os córregos locais, indicando contaminação da água; nas áreas de pastagem, alguns 
trechos mais declivosos da unidade de paisagem (especialmente na porção sul do município) apresentavam sinais de pisoteio de gado. É a unidade de paisagem que concentra as áreas potencialmente degradáveis por atividades agrícolas mal planejadas (ou não planejadas).

\section{Unidade IV}

Esta unidade é caracterizada pela formação geológica Piramboia, relevo predominante de colinas de topos convexos, alta dissecação do relevo e morrotestemunhos/cuestas. Solo do tipo neossolo litólico. No uso do solo e cobertura vegetal, destacam-se as pastagens, matas primária/secundária e afloramentos rochosos nos morrotestemunhos. Está inserida dentro da área da APA e é nessa unidade onde encontra-se o morro-testemunho Torre de Pedra.

Por apresentar as maiores declividades, essa unidade de paisagem apresenta riscos mais altos de erosão e processos que levem ao desequilíbrio geoecológico. Além de pastagens com sinais de pisoteio, os córregos dessa unidade de paisagem apresentavam grandes bolsões de areias, com suas margens bastante erodidas, sem proteção de mata ciliar.

\section{Recomendações de uso para cada unidade de paisagem}

Após a delimitação das unidades de paisagem, foram estabelecidos recomendações de uso do solo para cada unidade. Também foram considerados quais os benefícios ecossistêmicos mais adequados à exploração em cada unidade de paisagem, de modo a inserir cada uma delas na dinâmica econômica do município mitigando os impactos ambientais negativos ou já existentes em cada unidade.

\section{Unidade I}

- Reflorestamento

- Manejo da área de mineração

- Atividades agrícolas

- Pastagens nas áreas menos declivosas

A maior questão dessa unidade de paisagem é o manejo da área de mineração, que está em processo de desativação. O imóvel onde está localizada a mineração (Fazenda 
São Jorge) também constitui um polo turístico, por ser um local com infraestrutura para eventos de médio porte. Contudo, é necessário avaliar o impacto ambiental que a atividade mineradora pode deixar na unidade.

\section{Unidade II}

- Reflorestamento

- Atividades agrícolas

- Pastagens nas áreas menos declivosas

Unidade de paisagem com as menores pressões de desequilíbrio ecológico. Há áreas da UP com várias chácaras de veraneio e uma atração turística, o alambique municipal. Por ser a UP com relevo menos declivoso, tem grande fluxo de automóveis em relação a outras UPs, inclusive trânsito de caminhões transportando areia.

\section{Unidade III}

- Reflorestamento

- Atividades agrícolas

- Pastagens

- Regulamentação do despejo de esgoto da área urbana

Essa unidade abrange o meio urbano do município. Por essa razão, há a necessidade da implementação de ações relacionadas à recuperação de áreas degradadas por lixo e despejo de esgoto. A Sabesp (Companhia de Saneamento Básico do Estado de São Paulo) é a prestadora responsável por esses serviços no município.

\section{Unidade IV}

- Reflorestamento

- Atividade agrícola

- Geoturismo

Unidade com maior potencial turístico, especificamente com ênfase no Geoturismo. Recomenda-se estabelecimento de atividades turísticas cujo impacto ambiental seja majoritariamente positivo para a região em aspectos econômicos e ambientais. Nessa unidade de paisagem encontram-se elementos relacionados na Zona de Potencial Turístico previsto no plano de manejo da APA, como a Torre de Pedra e o Morro agudo. 


\section{DISCUSSÃO}

A análise do plano de manejo levou a conclusão de que parte dos estudos de plano de manejo da APA estão desatualizados e a delimitação da APA não está abrangendo toda a dinâmica paisagística do município (SILVAa, 2006) (SÃO PAULO, 2011). Silva (2006) apresenta uma proposta de novos limites para o perímetro Botucatu da APA que seriam mais adequados para abrangência de todos os atributos presentes na região.

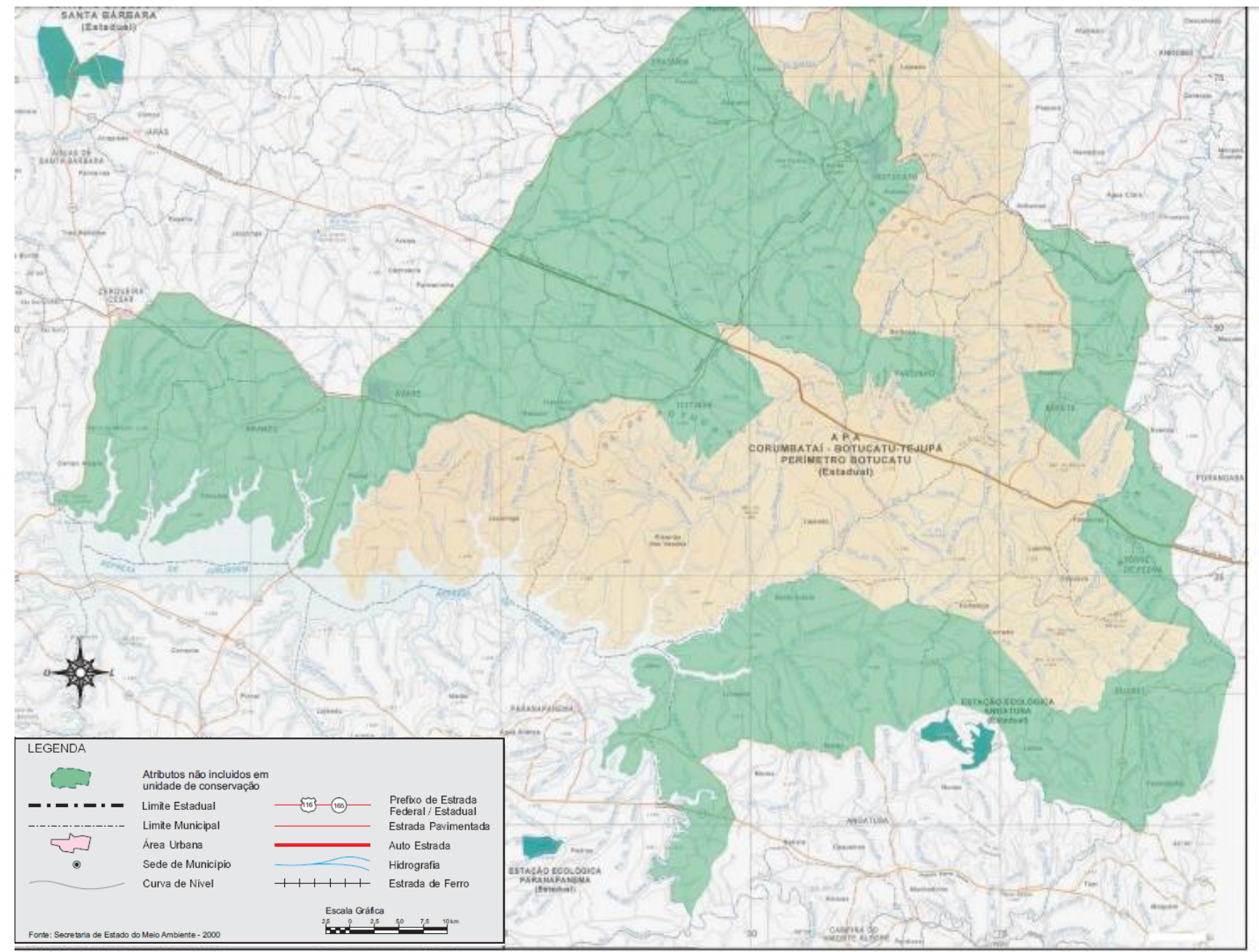

Mapa 12: APA Corumbataí, Botucatu, Tejupá - Perímetro Botucatu. Fonte: SILVAa, 2006. 
Por meio das observações realizadas nos trabalhos de campo, constatou-se que:

- Há degradação no morro-testemunho (não há restrição de acesso, e há sinais de degradação ambiental como despejo de lixo e pichações, além da falta de planejamento e monitoramento da visitação).

- Feições erosivas graves no solo da região.

- Áreas extensas de silvicultura.

A degradação ambiental está associada principalmente à pecuária e pastagens. Segundo o IBGE, 2018, há 7787 cabeças de gado no município.

O mapeamento das unidades de paisagem foi definido pela função e dinâmica de cada unidade, considerando como variáveis operacionais o uso do solo e cobertura vegetal, forma de relevo, pedologia, litologia. O estabelecimento das unidades de paisagem também levou em consideração que cada unidade pode disponibilizar um tipo de benefício ecossistêmico, com diferentes tipos de benefícios oferecidos por todas elas.

O estudo das consequências e impactos de cada atividade também foi necessário, para que as recomendações de uso fossem adequadas. Para isso, o quadro proposto a seguir, baseado em Sanchez (2013), foi seguido.

Quadro 7: Levantamento preliminar de impactos ambientais. Organização: Jéssica Vieira de Faria, 2018. Baseado em Sanchez, 2013.

\begin{tabular}{|l|l|l|l|}
\hline Atividade & $\begin{array}{l}\text { Componentes } \\
\text { ambientais } \\
\text { envolvidas }\end{array}$ & \multicolumn{1}{c|}{ Riscos } & \multicolumn{1}{c|}{ Processos } \\
\hline Pastoreio & $\begin{array}{l}\text { Solo, hidrografia, } \\
\text { vegetação, relevo. }\end{array}$ & $\begin{array}{l}\text { Perda de área } \\
\text { agricultável, erosão } \\
\text { em áreas de } \\
\text { encosta }\end{array}$ & Pisoteio \\
\hline Culturas perenes & $\begin{array}{l}\text { Solo, hidrografia, } \\
\text { vegetação, relevo. }\end{array}$ & $\begin{array}{l}\text { Poluição das águas } \\
\text { e solo, perda de } \\
\text { área agricultável }\end{array}$ & $\begin{array}{l}\text { Despejo de detritos } \\
\text { no solo e na água }\end{array}$ \\
\hline Mineração & $\begin{array}{l}\text { Solo, hidrografia, } \\
\text { vegetação, relevo. }\end{array}$ & $\begin{array}{l}\text { Poluição das águas } \\
\text { e solo, alteração do } \\
\text { relevo }\end{array}$ & $\begin{array}{l}\text { Escavação, despejo } \\
\text { de detritos da } \\
\text { mineração }\end{array}$ \\
\hline
\end{tabular}


Os levantamentos bibliográficos, analisados em conjunto com os mapeamentos e os trabalhos de campo, levaram à análise dos benefícios ecossistêmicos disponíveis nas diferentes unidades de paisagem. Os benefícios ecossistêmicos apresentados foram baseados em GRAY et al., 2013 e sua definição de abiotic ecosystem services ${ }^{12}$. Vale ressaltar que é fundamental para a tomada de decisões sobre o planejamento do uso territorial, considerar esses benefícios ecossistêmicos. Neste ponto, os benefícios foram classificados como: fornecimento (produção de alimentos e água potável); regulação (como controle do clima); suporte (como ciclo da polinização) e cultural (como benefícios recreativos).

A unidade de paisagem I destaca-se por apresentar benefícios ecossistêmicos relacionado ao fornecimento de bens.

Já a unidade de paisagem II tem como benefícios ecossistêmicos a assistência a prevenção da erosão dos solos, por ser um unidade de paisagem com argissolo vermelho amarelo, além de relevo menos declivoso, constituindo um benefício relacionado ao suporte.

Na unidade de paisagem III, os benefícios ecossistêmicos destacados são os de suporte à habitação, principalmente por que é nessa unidade que está localizada a área urbana de Torre de Pedra, polo demográfico do município.

Por fim, a unidade de paisagem IV apresenta benefícios ecossistêmicos culturais e recreativos, devido à presença do morro-testemunho Torre de Pedra nessa unidade. Aqui, reitera-se que a modalidade de turismo mais adequada é o geoturismo, devido às peculiaridades da geodiversidade dessa área de estudo, já apontadas anteriormente. Além disso, o geoturismo também prevê atividades escolares e científicas, o que pode englobar outros benefícios ecossistêmicos, como o monitoramento ambiental, a constituição de geoparques e a realização de trabalhos de campo monitorados. Contudo, outras áreas em outras unidades de paisagem também apresentam atrativos para o turismo rural, como a fazenda São Jorge e o alambique, ambos na unidade de paisagem I.

Todas as unidades de paisagem apresentam benefícios ecossistêmicos relacionados ao abastecimento e captação de águas, pois a captação das precipitações em suas áreas contribui para a recarga do Aquífero Guarani. Os benefícios ecossistêmicos identificados para cada uma das unidades de paisagem podem ser incorporados como subsídios para ações de planejamento e gestão constantes em futuras políticas públicas

\footnotetext{
12 Tradução livre: benefícios ecossistêmicos de fatores abióticos.
} 
municipais. Assim, sugere-se um panorama das potencialidades e restrições de uso e ocupação da terra presentes na área de estudo, propondo uso do solo com ênfase à preservação do morro-testemunho de Torre de Pedra e seu entorno.

Espera-se que a pesquisa auxilie o planejamento territorial do município, dando subsídios aos gestores públicos. É importante considerar a legislação ambiental para esse planejamento, assim como realizar um levantamento de projetos dentro da APA que possam auxiliar essa atividade.

Quadro 8: Benefícios ecossistêmicos das unidades de paisagem de Torre de Pedra (SP). Organização: Jéssica Vieira de Faria, 2018.

\begin{tabular}{|c|c|c|c|}
\hline $\begin{array}{l}\text { Unidade de } \\
\text { paisagem }\end{array}$ & Benefícios ecossistêmicos & Recomendações de uso & Riscos \\
\hline Unidade I & $\begin{array}{l}\text { Fornecimento de materiais; } \\
\text { abastecimento e captação de } \\
\text { águas }\end{array}$ & $\begin{array}{l}\text { - } \quad \text { Reflorestamento } \\
\text { - } \quad \text { Manejo da área de } \\
\text { mineração } \\
\text { - } \quad \text { Atividades } \\
\text { agrícolas } \\
\text { - } \quad \text { Pastagens nas áreas } \\
\text { menos declivosas }\end{array}$ & $\begin{array}{l}\text { Erosão do solo por } \\
\text { pisoteio, poluição dos } \\
\text { córregos }\end{array}$ \\
\hline Unidade II & $\begin{array}{l}\text { Assistência a prevenção da erosão } \\
\text { dos solos; abastecimento e } \\
\text { captação de águas }\end{array}$ & $\begin{array}{l}\text { - } \\
\text { - } \quad \text { Atividades } \\
\text { agrícolas } \\
\text { - } \quad \text { Pastagens nas áreas } \\
\text { menos declivosas }\end{array}$ & Poluição dos córregos \\
\hline Unidade III & $\begin{array}{l}\text { Suporte à } \frac{2}{\text { habitação; }} \\
\text { abastecimento e captação de } \\
\text { águas }\end{array}$ & $\begin{array}{l}\text { - } \\
\text { - } \quad \text { Atividades } \\
\text { agrícolas } \\
\text { - } \quad \text { Pastagens } \\
\text { - } \quad \text { Regulamentação do } \\
\text { despejo de esgoto da área } \\
\text { urbana }\end{array}$ & $\begin{array}{l}\text { Erosão do solo por } \\
\text { pisoteio, poluição dos } \\
\text { córregos }\end{array}$ \\
\hline
\end{tabular}




\begin{tabular}{|l|llr|ll|l|}
\hline Unidade IV & $\begin{array}{l}\text { Culturais } \\
\text { (geoturismo); abastecimento }\end{array}$ & $\mathrm{e}$ & $\bullet$ & Atividade agrícola \\
captação de águas & & & Geoturismo & $\begin{array}{l}\text { Erosão do solo por } \\
\text { pisoteio, poluição dos } \\
\text { córregos, degradação do } \\
\text { morro-testemunho }\end{array}$ \\
\hline
\end{tabular}




\section{CONSIDERAÇÕES FINAIS}

A partir dos estudos realizados, verificou-se que há pouca produção científica sobre o município de Torre de Pedra e seu morro-testemunho. Também foi observado que, apesar de pontual, este trabalho apresenta relação com casos análogos que podem ser avaliados em conjuntura, como Torrinha (Torrinha, SP), Morro do Cuscuzeiro (Analândia, SP) e outros morros testemunho (Botucatu, SP).

Os trabalhos de campo foram fundamentais para o levantamento da situação ambiental atual do município. Observou-se atividades sem o devido planejamento, tais como silvicultura em interflúvios, pastagens em áreas declivosas e visitação não monitorada ao morro-testemunho Torre de Pedra (com pichações, lixo no entorno e sinais de degradação) que contribuíram para uma situação de risco ambiental potencial.

O levantamento bibliográfico apontou que os documentos oficiais do governo estão desatualizados, sendo que o limite da Área de Proteção Ambiental Corumbataí, Botucatu e Tejupá - Perímetro Botucatu não abrange todos os atributos que a APA visa proteger na região.

A discussão sobre a dinâmica paisagística e o potencial geoecológico do município contribui para a compreensão do funcionamento das paisagens do município, sob uma perspectiva sistêmica que engloba as diversas esferas presentes nessa dinâmica. É importante ressaltar que a avaliação do potencial não, necessariamente, corresponde à tendência de ocupação das unidades de paisagem.

A análise do mapeamento contribuiu para uma sistematização das informações disponíveis sobre o município, que podem auxiliar na tomada de decisões dos órgãos municipais, além da elaboração do mapa de unidades de paisagem.

O estabelecimento das unidades de paisagem é de suma importância, uma vez que dá subsídios para o planejamento e ordenamento territorial. Ao compreender os riscos de cada unidade de paisagem, é possível planejar e organizar as atividades realizadas em cada uma delas de modo a atender tanto as necessidades de preservação ambiental quanto as demandas econômicas do município. Assim, procurou-se contribuir com essa análise, fornecendo subsídios potenciais para a tomada de decisões governamentais para o planejamento do uso do solo do município.

Apesar dessa contribuição, contudo, ainda seriam necessários outros estudos e medidas: 
- $\quad$ Estudos socioeconômicos: uma avaliação da economia local e como a implementação sistemática do turismo poderia impactar as finanças municipais.

- Avaliação da infraestrutura local: análises sobre a capacidade do município de acolher turistas, no tocante à hospedagem, alimentação, entretenimento e segurança.

- Análises de impacto ambiental: como a atividade turística pode causar impactos positivos e negativos para o município.

Por fim, é fundamental reiterar que é necessário que haja a adoção de medidas de proteção ambiental no município, assim como aumentar a fiscalização para o cumprimento de determinações ambientais existentes. Nesse sentido, além de contribuir para os estudos de casos análogos, essa dissertação pode auxiliar o planejamento das atividades do município visando à prevenção dos impactos ambientais negativos. 


\section{REFERÊNCIAS BIBLIOGRÁFICAS}

AB’SABER, A. A Terra Paulista. In: Boletim Paulista de Geografia, no 23, AGB São Paulo, 1956.

AB’SABER, A. Regiões de Circundenudação Pós-Cretácea, no Planalto Brasileiro. In: Boletim Paulista de Geografia, nº 1, AGB São Paulo, 1949.

ALMEIDA, F.F.M. Fundamentos Geológicos do Relevo Paulista. Geologia do Estado de São Paulo, nº41, Instituto Geográfico e Geológico. São Paulo, 1974.

ALMEIDA, F.F.M. Relevo de Cuestas na Bacia Sedimentar do Rio Paraná. In.: Boletim Paulista de Geografia, n³, AGB São Paulo, 1949

AMORIM, R. R.; OLIVEIRA, R.C. As unidades de paisagem como uma categoria de análise geográfica: o exemplo do município de São Vicente-SP. In: Sociedade \& Natureza, 20 (2), Uberlândia, 2008. P. 177-198. Disponível em <http://www.scielo.br/pdf/sn/v20n2/a11v20n2.pdf> Acesso em janeiro de 2016.

ARQUIVO PÚBLICO DO ESTADO DE SÃO PAULO. Fotografias aéreas de Porangaba, SP, e seu distrito de Torre de Pedra. 1940

BASTIAN, O. Landscape classification in Saxony (Germany) - a tool for holistic regional planning. In: Landscape and Urban Planning, 50, 2000. p. 145-155.

BERTALANFFY, L.V. Teoria Geral dos Sistemas. Petrópolis: Vozes, 1973.

BERTRAND,G. Paisagem e Geografia Física Global - Esboço metodológico. In: Revista RA'e GA, n. 8, Curitiba, 2004. p. 141-152.

BEUNEUN, R.; OPDAM, P. When landscape planning becomes landscape governance, what happens to the science? In: Landscape and Urban Planning, 100. 2011. p. 324-326.

BEZERRA, A. F. Sistema de espaços livres públicos e índice de qualidade de áreas verdes (IQAV) da paisagem urbana de São Bernardo do Campo (SP). Tese de Doutorado. Faculdade de Filosofia, Letras e Ciências Humanas (FFLCH). Universidade de São Paulo. São Paulo, 2013.

BOFETE TURISMO. Castelo/Fazenda São Jorge. Disponível em:

$<$ https://bofeteturismo.tur.br/espaco-castelo-fazenda-sao-jorge>. Acesso em maio de 2018.

BRASIL. LEI No 9.985, DE 18 DE JULHO DE 2000. Sistema Nacional de Unidades de Conservação (SNUC). 2000. Disponível em: < http://www.planalto.gov.br/ccivil_03/leis/L9985.htm>. Acesso em maio de 2018.

CASSETI, Valter. Geomorfologia. [S.1.]: [2005]. Disponível em: <http://www.funape.org.br/geomorfologia/>. Acesso em fevereiro de 2018. 
CERQUEIRA, M. O. A vulnerabilidade ambiental do Território do Sisal-Bahia. Feira de Santana, 2015. 152 f. Orientadora: Jocimara Souza Britto Lobão. Dissertação (mestrado) - Universidade Estadual de Feira de Santana.

CENTRO DE PREVISÃO DE TEMPO E ESTUDOS CLIMÁTICOS (CPTEC). Instituto Nacional de Pesquisas Espaciais (INPE). Disponível em: $<$ https://www.cptec.inpe.br/>. Acesso em fevereiro de 2018.

CRUZ, Leonardo de Oliveira. Historicidade do contato entre índios e não índios no oeste paulista. In: Revista de Iniciação Científica da FFC, v. 6, n. 1/2/3, p. 39-45, 2006. 2006. Disponível em: < http://www2.marilia.unesp.br/revistas/index.php/ric/article/viewFile/145/136>. Acesso em maio de 2018.

COMGEO-SP. Disponível em: <http://www.ambiente.sp.gov.br/comgeo/> Acesso em dezembro de 2016.

CONTI, J. B. Ecoturismo, Paisagem e Geografia. In Rodrigues, A. (org) Ecoturismo no Brasil. Possibilidades e limites. São Paulo: Contexto, 2003.

CORNÉLIO, R. C. Fazendo possui castelo medieval. JCNET, 2012. Disponível em: https://www.jcnet.com.br/Regional/2012/01/fazenda-possui-castelo-medieval.html>. Acesso em maio de 2018.

CORVALAN, S. B. Zoneamento ambiental da APA Corumbataí (SP) de acordo com critérios de vulnerabilidade ambiental. Tese de Doutorado. Universidade Estadual Paulista: Rio Claro, 2009. Disponível em: < https://repositorio.unesp.br/bitstream/handle/11449/102947/corvalan_sb_dr_rcla.pdf?se quence $=1>$. Acesso em maio de 2018 .

DALBEM, R.P; MOURA, A.R.; JORGE, F.V.; MOROKAWA, F.V.; VALASKI, S. Delimitação de Unidades de Paisagem: Conceito e Método aplicados ao município de Paranaguá, PR, Brasil. In: Anais do XI Simpósio Brasileiro de Geografia Física Aplicada. São Paulo: USP, 2005. Disponível em: <http://www.labs.ufpr.br/site/wpcontent/uploads/2014/07/dalbem_anaisdecongressos_sbgfa_2005.pdf > Acesso em janeiro de 2016.

DELPOUX, M. Métodos em questão: ecossistema e paisagem. Instituto de Geografia, Universidade de São Paulo, São Paulo, 23 p. 1974.

DEPARTAMENTO NACIONAL DE PRODUÇÃO MINERAL (DNPM). Universo da mineração brasileira. Brasília, 2007, 83 p. Disponível em:

<http://www.dnpm.gov.br/dnpm/publicacoes-economia-mineral/arquivos/universo-damineracao-brasileira-2007>. Acesso em maio de 2018.

EMPRESA BRASILEIRA DE PESQUISA AGROPECUÁRIA (EMBRAPA). Solos Tropicais, 2018. Disponível em: <http://www.agencia.cnptia.embrapa.br/gestor/solos_tropicais/arvore/CONTAG01_1_2 212200611535.html>. Acesso em fevereiro de 2018. 
ESTADO DE SÃO PAULO. Decreto Estadual No 20,960, de 8 de junho de 1983. Disponível em

<http://licenciamento.cetesb.sp.gov.br/legislacao/estadual/decretos/1983_Dec_Est_2096 0.pdf> . Acesso em junho de 2016.

FARIA, J. V. de. Beleza Cênica de Torre de Pedra (SP) e seu atrativo turístico: potencialidades e fragilidades. Trabalho de Graduação Individual. Departamento de Geografia da FFLCH - USP. Orientador: Jurandyr Luciano Sanches Ross. Ano: 2014.

FERREIRA, V. de O. A abordagem da paisagem no âmbito dos estudos ambientais integrados. In: GeoTextos, vol. 6, n. 2, dez. 2010. p. 187-208.

GIACOMELI, H.; AZZI, A.A. \& ZANARDO, A. Tipos de Silicificação reconhecidos no Nordeste da Bacia do Paraná. Disponível em: $<$ https://www.google.com.br/search?q=TIPOS+DE+SILICIFICA\%C3\%87\%C3\%83O+ RECONHECIDOS+NO+NORDESTE+DA+BACIA+DO+PARAN\%C3\%81\&oq=TIP OS+DE+SILICIFICA $\% \mathrm{C} 3 \% 87 \% \mathrm{C} 3 \% 83 \mathrm{O}+\mathrm{RECONHECIDOS+NO+NORDESTE+DA}$ +BACIA+DO+PARAN\%C3\%81\&aqs=chrome..69i57.794j0j7\&sourceid=chrome\&esp $\mathrm{v}=210 \&$ es_sm=93\&ie $=\mathrm{UTF}-8 \#>$. Acesso em março de 2017.

GIGLIOTTI, M. S. Zoneamento Geoambiental da região da Baixada Santista- SP como subsídio ao uso e ocupação das terras. Campinas, 2010. Orientador: Regina Célia e Oliveira. Dissertação (mestrado) Universidade Estadual de Campinas, Instituto de Geociências.

GOLLEDGE, R. G. The Nature of Geographic Knowledge. In: Annals of the Association of American Geographers, 92(1), 2002, pp. 1-14

GOOGLE EARTH. 2018. Disponível em: <https://www.google.com.br/intl/pt$\mathrm{BR} /$ earth/>. Acesso em maio de 2018.

GRAY, M.; GORDON, J.E.; BROWN, E.J. Geodiversity and the ecosystem approach: the contribution of geoscience in delivering integrated environmental management. In: Proceedings of the Geologists' Association, 124. 2013. p. 659-673.

GRIESE, Juliana; MELO, Murilo Gambato. (Org.) ATLAS DA CUESTA. Botucatu: FEPAF, 2012. Disponível em: < http://itapoty.org.br/portal/atlas-da-cuesta>. Acesso em fevereiro de 2018.

GUERRA, A.J.T. \& MARÇAL, M.S. Geomoforlogia Ambiental. Rio de Janeiro: Bertrand Brasil, 2012.

INSTITUTO BRASILEIRO DE GEOGRAFIA E ESTATÍSTICA (IBGE). Manual técnico de geomorfologia, $2^{\text {a }}$. edição. Rio de Janeiro: 2009.

IBGE CIDADES. Disponível em: < http://www.cidades.ibge.gov.br/ > Acesso em fevereiro de 2018.

IBGE. IBGE mostra a nova dinâmica da rede urbana brasileira. 2008. Disponível em: $<$ https://agenciadenoticias.ibge.gov.br/agencia-noticias/2013-agencia-de- 
noticias/releases/13558-asi-ibge-mostra-a-nova-dinamica-da-rede-urbanabrasileira.html> Acesso em maio 2018.

INSTITUTO GEOLÓGICO. Projetos Monumentos Paulistas. Secretaria do Verde e do Meio Ambiente, São Paulo, 2010.

INSTITUTO DE PESQUISAS TECNOLÓGICAS DO ESTADO DE SÃO PAULO (IPT) - Mapa Geomorfológico do Estado de São Paulo. São Paulo, 1981.

INSTITUTO FLORESTAL. APAs Estaduais. Disponível em: <http://fflorestal.sp.gov.br/unidades-de-conservacao/apas/ > Acesso em março de 2014.

LIMA, A.C.G. (Coord.) Inventário da Oferta Turística. Brasília: Ministério do Turismo, 2011. 38p.

MARTINELLI, M; PEDROTTI, F. A cartografia das unidades de paisagem: questões metodológicas. In: Revista do Departamento de Geografia. $N^{\circ} 14$. FFLCH-USP, São Paulo, 2001. Disponível em: <http://www.revistas.usp.br/rdg/article/viewFile/47311/51047> Acesso em janeiro de 2016.

MATEO-RODRIGUEZ, J. Geografia de los paisajes. UC, 2000.

MATEO-RODRIGUEZ, J.; SILVA, CAVALCANTI, A.P. Geoecologia da Paisagem, uma visão geossistêmica da análise ambiental. 2. ed. Fortaleza: UFC Edições, 2007. p. 222.

MATEO-RODRIGUEZ, J.M.., SILVA, E.V. A classificação das paisagens a partir de uma visão geossistêmica. In: Mercator - Revista de Geografia da UFC, ano 01, número 01. Fortaleza: UFC, $2002 . \quad$ Disponível em: <http://www.mercator.ufc.br/index.php/mercator/article/view/198/164> Acesso em ago. 2016.

MESSIAS, C.G.; FERREIRA, M.C. Aplicação do método de classificação contínua Fuzzy para o mapeamento da fragilidade do terreno em relação à ocorrência de ravinas no Parque Nacional da Serra da Canastra. In: Revista Ra'e Ga. Curitiba, v.39, p. 111-127, Abr/2017.

MONTEIRO, C.A.F. Geossistemas: a história de uma procura. São Paulo: Contexto, 2000, 128p.

NASCIMENTO, M. A. L. do; RUCHKYS, U. A.; MANTESSO-NETO, V. Geodiversidade, Geoconservação e Geoturismo - trinômio importante para a proteção do patrimônio geológico. São Paulo: Sociedade Brasileira de Geologia, 2008.

NEWSOME, D. \& DOWLING, R.K. Geotourism: The Tourism of Geology and Landscape. Woodeaton, Oxford: Goodfellow Pub., 2010. 
NEWSOME, D.; DOWLING, R.; LEUNG, Y. The nature and management of geotourism: A case study of two established iconic geotourism destinations. In: Tourism Management Perspectives. 2012. p. 19-27.

NOVAES, C. A.; Turismo Rural e Agroturismo Diferenciados de Turismo em Espaço Rural: uma proposta. In: Turismo no Espaço Rural: enfoques e perspectivas. São Paulo: ROCA, 2006. Cap. 21, p. 280-291

NUCCI, J. Metodologia para determinação da qualidade ambiental urbana. In: Revista do Departamento de Geografia. São Paulo: Departamento de Geografia da USP, 1998. p 209224.Disponível em: http://www.revistas.usp.br/rdg/article/viewFile/53740/57703

OLIVEIRA, R. A. R. N. de . Arenitos silicificados das Formações Pirambóia e Botucatu no Estado de São Paulo: processos geradores e aspectos geomorfológicos associados. Orientador: Paulo C. Gianini. Trabalho de Formatura, Instituto de Geociências, São Paulo: 2001.

PISSINATI, Mariza C.; ARCHELA, Rosely S. Geossistema território e paisagem método de estudo da paisagem rural sob a ótica betrandiana. In: Geografia - v. 18, n. 1, jan./jun. 2009 - Universidade Estadual de Londrina, Departamento de Geociências. Disponível em: <http://www.uel.br/revistas/uel/index.php/geografia/article/view/2445>. Acesso em dez. 2017.

PRALONG, J.P. A method for assessing tourist potential and use of geomorphological sites. In: Géomorphologie: relief, processus, environnment, vol. 11, n`3. França, 2005. p. 189-196.

PREFEITURA MUNICIPAL DE TORRE DE PEDRA, SÃO PAULO. Disponível em: $<$ http://www.torredepedra.sp.gov.br/>. Acesso em fevereiro de 2018.

RIBEIRO, R.R.; GUEDES, A.C.M.; SABBADINI, M.F. Projeto Monumentos Geológicos do Estado de São Paulo. Disponível em: <http://www.igeologico.sp.gov.br/downloads/poster/11SGS_Ribeiro.pdf>. Acesso em janeiro de 2016.

ROSS, J. L. S. Geomorfologia, ambiente e planejamento. São Paulo: Contexto, 1990. (Coleção Repensando a Geografia).

ROSS, J. L. S. O registro cartográfico dos fatos geomórficos e a questão da taxionomia do relevo. Revista do Departamento de Geografia da USP. São Paulo: n. 6. 1992. 17-29p.

ROSS, J.L.S. \& MOROZ, I. Mapa Geomorfológico do Estado de São Paulo, 1 :50.000. Instituto de Pesquisas Tecnológicas - IPT, SP, 1997.

ROSS, J.L.S. \& MOROZ, I. Mapa Geomorfológico do Estado de São Paulo, In: Revista do Departamento de Geografia. São Paulo: USP, 1996. Disponível em: < http://www.revistas.usp.br/rdg/article/view/53703>. Acesso em fevereiro de 2018.

ROSS, J.L.S. Análise Empírica da Fragilidade dos Ambientes Naturais e Antropizados. In: Revista do Departamento de Geografia. N8. FFLCH-USP, São Paulo, 1994. 
ROSS, J.L.S. Geomorfologia Ambiente e Planejamento (3a. Reimpressão). São Paulo : Contexto, 2010.

ROSSI, M. Mapa pedológico do Estado de São Paulo: revisado e ampliado. São Paulo: Instituto Florestal, 2017, V.1, 118p. Disponível em: $<$ http://iflorestal.sp.gov.br/files/2017/11/MAPAPEDOLOGICO_SP_ROSSI_2017.pdf >. Acesso em maio de 2018.

RUBAN, D.A. Geotourism - A geographical review of the literature. In: Tourism Management Perspectives. 2015. p. 1-15.

S.O.S CUESTA DE BOTUCATU. Área de Proteção Ambiental Corumbataí, Botucatu, Tejupá. Disponível em: 〈http://www.soscuesta.org.br/apa_botucatu.htm> Acesso em julho de 2016.

SÁNCHEZ, L. E. Avaliação de impacto ambiental: conceitos e métodos. São Paulo: Oficina de textos, 2013.

SÃO PAULO. SMA. FF. Plano de Manejo da Área de Proteção Ambiental Corumbataí, Botucatu e Tejupá - Perímetro Botucatu. Volume 1. São Paulo, abril de 2011. Disponível em: < http://arquivos.ambiente.sp.gov.br/fundacaoflorestal/2016/03/Volume-1Diagn\%C3\%B3stico.pdf>. Acesso em fevereiro de 2018.

SÃO PAULOa. SMA. FF. Plano de Manejo da Área de Proteção Ambiental Corumbataí, Botucatu e Tejupá - Perímetro Botucatu. Volume 2. São Paulo, abril de 2011. Disponível em: <http://s.ambiente.sp.gov.br/fundacaoflorestal/planosmanejo/concluidos/apa-botucatu/volume2.pdf >. Acesso em fevereiro de 2018.

SERVIÇO GEOLÓGICO DO BRASIL-CRPM . Geodiversidade do Brasil. 2008. <http://www.cprm.gov.br/publique/media/geodiversidade_brasil.pdf> Acesso em dezembro de 2017.

SERVIÇO GEOLÓGICO DO BRASIL - CPRM. Mapa Geológico do Estado de São Paulo 1: 750.000. 2018. Disponível em: < http://www.cprm.gov.br/publique/Geologia/Geologia-Basica/Cartografia-GeologicaRegional-624.html>. Acesso em fevereiro de 2018.

SERVIÇO GEOLÓGICO DO BRASIL - CPRM a. Breve descrição das unidades litoestratigráficas aflorantes no estado de São Paulo. Mapa Geológico do Estado de São Paulo 1: 750.000. 2018. Disponível em: < http://rigeo.cprm.gov.br/xmlui/bitstream/handle/doc/2966/breve_descri\%C3\%A7\%C3\% A3o_unidades.pdf? sequence $=1 \&$ isAllowed $=y>$. Acesso em fevereiro de 2018.

SERVIÇO GEOLÓGICO DO BRASIL - CPRM. GeoWebApp. 2018. Disponível em: < http://geowebapp.cprm.gov.br/ViewerWEB/>. Acesso em fevereiro de 2018.

SERVIÇO GEOLÓGICO DO BRASIL - CPRM. Geodiversidade. 2016. Disponível em: <http://www.cprm.gov.br/publique/Gestao-Territorial/Geodiversidade162>. Acesso em dezembro de 2017. 
SILVA, F.R. Tectonismo Gerador do Alto Estrutural de Torre de Pedra, Bacia do Paraná, SP. Orientador: Cláudio Riccomini. Trabalho de Formatura-Instituto de Geociências da Universidade de São Paulo. São Paulo, 2008.

SILVAa, I. X. Gestão das áreas de proteção ambiental - APAs - no estado de São Paulo: estudo e avaliação. Dissertação de Mestrado. Faculdade de Filosofia, Letras e Ciências Humanas, USP, 2006, 199 p.

SOTO, S.; PINTÓ, J. Delineation of natural landscape units for Puerto Rico. In: Applied Geography, 30. 2010. p. 720-730.

SPÖRL, C. Análise de fragilidade ambiental relevo-solo com aplicação de três modelos alternativos nas altas bacias do rio Jaguari-Mirim, Ribeirão do Quartel e Ribeirão da Prata. Dissertação de Mestrado. Orientador: Prof. Dr. Jurandyr Luciano Sanches Ross. FFLCH: Departamento de Geografia, 2001.

TÁVORA,G.S.G.; TURETTA, A.P.D. An approach to map landscape functions in Atlantic Forest— Brazil. In: Ecological Indicators, 71. 2016. p. 557-566.

TORRE DE PEDRA. Site da Prefeitura Municipal de Torre de Pedra, 2018. Disponível em: < http://www.torredepedra.sp.gov.br/>. Acesso em fevereiro de 2018.

TRICART, Jean. Ecodinâmica. Rio de Janeiro: Superintendência dos Recursos Naturais e Meio Ambiente (SUPREN), 1977.

UNICAMP - Banco de dados do Centro de Pesquisas Meteorológicas e Climáticas aplicadas a Agricultura - Municípios Paulistas. Disponível em: <http://www.cpa.unicamp.br/outras-informacoes/clima_muni_613.html> Acesso em novembro de 2016.

VALE, C.C. Teoria Geral do Sistema: histórico e correlação com a Geografia e o Estudo da Paisagem. In: Entre-Lugar, Dourados, MS, ano 3, n.6, p 85-108, 2012

WILLEMEN, L.; VERBURGA, P.H.; HEINB, L.; van MENSVOORTA, M.E.F. Spatial characterization of landscape functions. In: Landscape and Urban Planning, 88. 2008. p. 34-43. 
ANEXO I

Ficha de Trabalho de Campo - Torre de Pedra/SP

Registro №:

Data Horário

Coordenadas UTM

Altimetria

\section{Condições climáticas :}

\section{Características do local}

Relevo

\begin{tabular}{|l|l|}
\hline & Colinas topos convexos. \\
\hline & Escarpas íngremes/cuestas \\
\hline & Morros \\
\hline & Outros: \\
\hline
\end{tabular}

\section{Pedologia}

\begin{tabular}{|l|l|}
\hline & Argissolos \\
\hline & Depósitos arenosos \\
\hline & Afloramento rochoso \\
\hline & Latossolos \\
\hline
\end{tabular}

Cobertura vegetal e uso do solo

\begin{tabular}{|l|l|}
\hline & Mata primária \\
\hline & Mata secundária \\
\hline & Pastagem \\
\hline & Agricultura \\
\hline & Outros: \\
\hline
\end{tabular}

Observações 